\title{
Meliponini neotropicais: o gênero Partamona Schwarz, 1939 (Hymenoptera, Apidae, Apinae) - bionomia e biogeografia
}

\author{
João M. F. Camargo ${ }^{1,2}$ \\ Silvia R. M. Pedro ${ }^{1}$
}

\begin{abstract}
Aвstract. Neotropical Meliponini: the genus Partamona Schwarz, 1939 (Hymenoptera, Apidae, Apinae) - bionomy and biogeography. This work, dedicated to the study of nesting habits of the species of the Neotropical genus Partamona Schwarz, is a sequence to the taxonomic revision recently published elsewhere. A total of 214 nests and nest aggregations of 18 species [Partamona epiphytophila Pedro \& Camargo, 2003; P. testacea (Klug, 1807); P. mourei Camargo, 1980; P. vicina Camargo, 1980; P. auripennis Pedro \& Camargo, 2003; P. combinata Pedro \& Camargo, 2003; P. chapadicola Pedro \& Camargo, 2003; P. nhambiquara Pedro \& Camargo, 2003; P. ferreirai Pedro \& Camargo, 2003; P. pearsoni (Schwarz, 1938); P. gregaria Pedro \& Camargo, 2003; P. batesi Pedro \& Camargo, 2003; P. ailyae Camargo, $1980 ; P$. cupira (Smith, 1863); P. mulata Moure in Camargo, 1980; P. seridoensis Pedro \& Camargo, 2003; P. criptica Pedro \& Camargo, 2003; P. helleri (Friese, 1900)] were studied , including data about habitat, substrate, structural characteristics, construction materials and behavior. The descriptions of the nests are illustrated with 48 drawings. Partial data of the nests of P. bilineata (Say, 1837), P. xanthogastra Pedro \& Camargo, 1997, P. orizabaensis (Strand, 1919), P. peckolti (Friese, 1901), P. aequatoriana Camargo, 1980, P. musarum (Cockerell, 1917) and P. rustica Pedro \& Camargo, 2003 are also presented. Nests of $P$. grandipennis (Schwarz, 1951), P. yungarum Pedro \& Camargo, 2003, P. subtilis Pedro \& Camargo, 2003, P. vitae Pedro \& Camargo, 2003, P. nigrior (Cockerell, 1925), P. sooretamae Pedro \& Camargo, 2003 and P. littoralis Pedro \& Camargo, 2003 are unknown. The species of Partamona build notable nest entrance structures, with special surfaces for incoming / exiting bees; some of them are extremely well-elaborated and ornamented, serving as flight orientation targets. All species endemic to western Ecuador to Mexico with known nesting habits (P. orizabaensis, $P$. peckolti, $P$. xanthogastra, $P$. bilineata, $P$. aequatoriana and $P$. musarum) build their nests in several substrates, nonassociated with termitaria, such as cavities and crevices in walls, among roots of epiphytes and in bases of palm leaves, in abandoned bird nests, under bridges, and in other protected places, except $P$. peckolti that occasionally occupies termite nests. In South America, on the eastern side of the Andes, only P. epiphytophila and $P$. helleri nest among roots of epiphytes and other substrates, non-associated with termitaria. All other species studied ( $P$. batesi, $P$. gregaria, $P$. pearsoni, P. ferreirai, $P$. chapadicola, $P$. nhambiquara, . vicina, . mourei, $P$. auripennis, $P$. combinata, $P$. cupira, $P$. mulata, $P$. ailyae, $P$. seridoensis, $P$. criptica and $P$. rustica) nest inside active termite nests, whether epigeous or arboreous. The only species that builds obligate subterranean nests, associated or not with termite or ant nests (Atta spp.) is P. testacea. Nests of Partamona have one vestibular chamber (autapomorphic for the genus) closely adjacent to the entrance, filled with a labyrinth of anastomosing pillars and connectives, made of earth and resins. One principal chamber exists for food and brood, but in some species one or more additional chambers are filled with food storage pots. In nests of $P$. vicina, there is one atrium or "false nest", between the vestibule and the brood chamber, which contains involucral sheaths, cells and empty pots. All structures of the nest are supported by permanent pillars made of earth and resins (another autapomorphy of the genus). The characters concerning nesting habits were coded and combined with morphological and biogeographic data, in order to hypothesize the evolutive scenario of the genus using cladistic methodology. The phylogenetic hypothesis

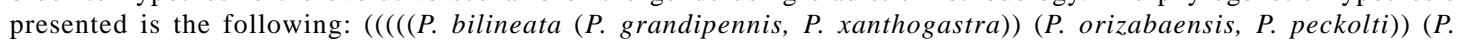
aequatoriana, P. musarum)) P. epiphytophila, P. yungarum, $P$. subtilis, $P$. vitae $)(((((P$. testacea $(P$. mourei, $P$. vicina $))(P$. nigrior (P. auripennis, P. combinata))) (P. ferreirai (P. pearsoni (P. gregaria (P. batesi (P. chapadicola, P. nhambiquara)))))) ((((P. ailyae, P. sooretamae) P. cupira, P. mulata) P. seridoensis) P. criptica, P. rustica, P. littoralis)) P. helleri))). One area cladogram is presented. Dates of some vicariance / cladogenesis events are suggested. For bilineata / epiphytophila group, which inhabits the Southwestern Amazonia and the Chocó-Mexican biogeographical components, the origin of ancestral species is attributed to the Middle Miocene, when the transgressions of the Maracaibo and Paranense seas isolated the tropical northwestern South America from the eastern continental land mass. The next cladogenic event in the history of the bilineata / epiphytophila group is attributed to the Plio-Pleistocene, when the Ecuadorian Andes reached more than $3000 \mathrm{~m}$, and the ancestral species was fragmented in two populations, one occupying the western Andes (ancestral species of the bilineata subgroup) and other the southwestern Amazon (ancestral species of the epiphytophila subgroup). Other aspects of the history of Partamona are also discussed.
\end{abstract}

KEywords. Biogeography; Meliponini; nests; Partamona; phylogeny.

\footnotetext{
1. Departamento de Biologia, Faculdade de Filosofia, Ciências e Letras de Ribeirão Preto, Universidade de São Paulo. Av. Bandeirantes 3900, 14040-901 Ribeirão Preto-SP, Brasil. Endereço eletrônico: jmfdcama@usp.br / silviarmp@ffclrp.usp.br

2. Pesquisador do CNPq.
} 


\section{INTRODUÇÃO}

Na primeira parte deste estudo (Pedro \& Camargo 2003), tratamos da revisão, distribuição geográfica e relações filogenéticas das espécies de Partamona. Foram reconhecidas 33 espécies, 17 das quais, novas para a ciência. Algumas dessas espécies são praticamente idênticas quanto à morfologia e padrão de cores das abelhas adultas, e só puderam ser reconhecidas como tal, com base em informações sobre os hábitos de nidificação e atributos da estrutura de entrada dos ninhos.

Nesta segunda parte, são estudados os hábitos de nidificação das espécies - substratos utilizados e atributos dos ninhos -, que não só estendem em muito o significado do fenótipo, como, também, permitem uma melhor delimitação das espécies e uma apreciação integrada de sua história evolutiva.

Dentre os Meliponini, as espécies de Partamona são as construtoras dos ninhos mais formidáveis que se conhece, especialmente em relação às estruturas de entrada. Não há nada comparável à diversidade de desenhos e ornamentos que estas produzem junto às entradas dos ninhos.

Na primeira parte do texto são apresentados comentários gerais sobre os hábitos de nidificação, seguidos de discussões sobre o significado dos caracteres e direção evolutiva, quando esta é possível de ser inferida, pelo menos tentativamente. A análise dos caracteres dos ninhos é feita em conjunto com os resultados da análise cladística e da biogeografia previamente apresentadas por PEDRo \& CAMARgo (2003).

Também são apresentadas descrições detalhadas dos ninhos, acompanhadas de ilustrações.

\section{MATERIAL E MÉTODOS}

Os ninhos foram obtidos ao longo de várias expedições ao Amazonas, a partir do ano de 1963, e viagens a outros espaços geográficos da região Neotropical. Ao todo, relacionamos 214 ninhos, ou conjuntos de ninhos (agregações), para os quais temos esquemas e desenhos de campo, diapositivos e dados sobre hábitat, substrato, arquitetura e materiais utilizados na construção, comportamento de defesa, etc. Além desses dados, há observações parciais sobre dezenas de outros ninhos. As estruturas de entrada, assim como todo o material testemunho, encontram-se depositados em nossa coleção, no Departamento de Biologia da Faculdade de Filosofia, Ciências e Letras de Ribeirão Preto - USP (RPSP).

A nomenclatura para os componentes dos ninhos é a mesma que aquela utilizada por KerR et al. (1967), CAMARgo (1970, 1980) e Wille \& Michener (1973). Os desenhos foram feitos com base nos esquemas de campo, peças originais e diapositivos. O estudo da textura e composição das entradas dos ninhos foi feito sob estereomicroscópio. Na matriz de dados para análise cladística (Tabela III), estão incluídos, com algumas modificações na codificação, os caracteres morfológicos previamente estudados por PEDRo \& CAMARGo (2003).

Para a polarização dos estados dos caracteres, as espécies Parapartamona vittigera Moure, 1992 e P. tungurahuana
(Schwarz, 1948), as únicas Parapartamona cujos ninhos são conhecidos, foram utilizadas como grupo externo, conforme hipotetizado por Pedro \& CAmargo (2003). Para as espécies de Partamona, cujos ninhos não estudamos pessoalmente, foram utilizados os dados disponíveis na literatura.

Os cladogramas (Figs. 57, 58) foram obtidos pelo programa numérico PAUP - Phylogenetic Analysis Using Parsimony, versão 3.1.1. (SwOFFord 1993), através de busca heurística, otimizados pela opção ACCTRAN e implementados através do programa MacClade, versão 3.05 (MADDISON \& MADDISON 1992).

\section{NIDIFICAÇÃO-ARQUITETURA E SUBSTRATO}

\section{Comentários Gerais}

Os Meliponini nidificam nos mais diversos tipos de substratos, como cavidades subterrâneas - associados ou não com ninhos de outros insetos sociais - , em termiteiros ativos, ocos de árvores e cipós, fendas em paredes e rochas, em ninhos de formigas arborícolas, em ninhos abandonados de aves, etc., até ninhos livres, fixados em galhos e troncos de árvores (SChwarz 1948; Kerr et al. 1967; CAMARgo 1970, 1974, 1996b; Wille \& Michener 1973; Michener 1974; Roubik 1989; Camargo \& Wittmann 1989; Camargo \& Posey 1990, entre outros). Em alguns gêneros, os hábitos de nidificação das espécies que os compõem, são muito uniformes, como em Geotrigona, por exemplo, onde os ninhos são todos subterrâneos e praticamente idênticos com relação à arquitetura. Em outros, como em Paratrigona, os hábitos são muito diversificados e os mais variados tipos de substratos são utilizados (CAmARGo \& Moure 1994). Alguns hábitos e soluções arquitetônicas, praticamente idênticos, podem ter sido adquiridos independentemente dentro da história dos táxons, como no caso de Camargoia, Schwarziana e Geotrigona, táxons que não compartilham um ancestral comum direto, mas que nidificam em cavidades subterrâneas e cujas soluções arquitetônicas são praticamente as mesmas. Supostamente, nestes casos, onde os ninhos são fixados no teto das cavidades subterrâneas, as soluções arquitetônicas para a sustentação do ninho e proteção contra água são muito limitadas, daí a convergência (CAMARgo 1974, 1996b; CAMARgo \& WitTMANN 1989).

Os modos de construção são os mais variados, mas todas as espécies conhecidas utilizam, como material básico para as edificações, cera e resinas vegetais puras ou misturadas (cerume). Algumas utilizam terra misturada com resinas, em partes específicas do ninho, como na estrutura de entrada e batume, no caso das espécies de Melipona, ou em várias partes do ninho (estrutura de entrada, pilares e conectivos do vestíbulo, pilares de sustentação dos favos de cria e potes de alimento), como no caso das espécies de Partamona. Estas obtêm a terra no próprio substrato de nidificação (termiteiro) ou em outros locais (lugares úmidos, como margens de rios e de poças d'água), transportando-a nas corbículas.

Os ninhos de Meliponini são constituídos de uma câmara 
ou de uma região de crias, com células, em favos ou cacho, e potes de armazenagem de pólen e mel, de tamanho e forma variados. As espécies construtoras de favos, usualmente os envolvem com um invólucro constituído de finas lamelas cerosas sobrepostas. As que nidificam em oco de árvores, constróem os mais variados tipos de batumes delimitando o espaço do ninho. Grossos batumes de terra e resinas são construídos pelas espécies de Melipona; os demais Meliponini o fazem com resinas e cerume. Nas espécies que constróem ninhos arborícolas livres, fixados em troncos ou galhos, o batume que envolve todo o ninho pode ser constituído de uma fina película de cerume, como em Tetragonisca weyrauchi (Schwarz, 1943), de partículas vegetais, formando um envoltório semelhante a um papelão, como em Trigona hyalinata (Lepeletier, 1936), de partículas vegetais e resinas, como em Trigona spinipes (Fabricius, 1793), de exinas contidas no excremento, como em Trigona corvina Cockerell, 1913 (Roubik e Moreno, in litteris) ou ainda de terra e resinas, como nos ninhos arborícolas livres, ou semi-expostos, de Partamona helleri.

As estruturas de entrada variam muito quanto à forma e materiais utilizados. Em alguns gêneros, como em Geotrigona, elas são praticamente idênticas em todas as espécies; em outros, como em Partamona, por exemplo, são peculiares a cada espécie. A estrutura de entrada, na maior parte das espécies de Meliponini, está relacionada com o sistema de defesa do ninho sendo, em alguns casos, inconspícua ou camuflada. Em Mourella caerulea (Friese, 1900), que constrói ninhos subterrâneos, é constituída apenas de um pequeno orifício na superfície do solo, sem qualquer ornamentação, o que exige que as abelhas façam complicados vôos de orientação, tanto na chegada como na saída do ninho (CAMARgo \& WitTMAnN 1989). Em Aparatrigona, usualmente, a entrada é constituída apenas de um orifício de cerca de 2,0 $\mathrm{mm}$, na superfície do termiteiro onde se hospeda, e que dificilmente pode ser reconhecida por um observador humano. Muitas espécies constróem tubos de cera, cerume, ou resinas, de diversos formatos, alguns muito longos $(40-50 \mathrm{~cm})$, como aqueles encontrados em algumas espécies de Scaptotrigona. No Amazonas, Trigona cilipes (Fabricius, 1804) que nidifica em formigueiros arborícolas (Azteca spp.), constrói longos tubos, principalmente de látex, muito pegajoso (KeRR et al. 1967); em um ninho, em início de construção, que observamos na região da foz do rio Daraã, AM (6445’W, 0²7’'S), em 17.VII.1999, o tubo, construído de resinas muito pegajosas, tinha cerca de $1,20 \mathrm{~m}$ de comprimento, fixado em um galho de árvore anexo ao formigueiro. As formigas não conseguiam caminhar sobre o tubo, ficando aderidas a ele. Tetragona goettei (Friese, 1900) constrói um pequeno tubo vertical, com partículas vegetais, que se desagregam facilmente quando perdem umidade. Enfim, há uma grande diversidade de tipos de estruturas de entrada mas, de um modo geral, relacionadas com a defesa do ninho. Em Partamona, algumas espécies constróem estruturas de entrada muito conspícuas e extremamente elaboradas e ornamentadas (Figs. 33-36, por exemplo), com função possivelmente mais relacionada com a orientação de pouso do que com a defesa, como descrito adiante.

O processo de fundação de novos ninhos, que envolve a escolha do local, o transporte de alimento e materiais do ninhomãe para as primeiras edificações, a enxameação, com a chegada da rainha jovem, e as relações de dependência com o ninhomãe que podem se estender por longos períodos, mesmo após a rainha ter iniciado a postura, foi detalhadamente descrito, pela primeira vez, por NoGUEIRA-NETo (1954) para várias espécies de Meliponini (revisões em Michener 1974; WiLle \& Orozco 1975; RouBIK 1989).

Sobre a fundação de novos ninhos e enxameação em Partamona, só existem as observações de Wille \& Orozco (1975), que relatam que, em linhas gerais, não diferem dos demais Meliponini. Esses autores observaram, em Costa Rica, Partamona orizabaensis (citada como Trigona cupira) durante o processo de ocupação de uma cavidade em um termiteiro (Nasutitermes sp.) abandonado que, anteriormente, abrigava um ninho de Scaura latitarsis (Friese, 1900). As relações entre o novo ninho e o parental, localizado a $110 \mathrm{~m}$ de distância, estenderam-se por 6 meses. Partamona orizabaensis não é uma espécie termitófila; utiliza vários tipos de substratos, como cavidades em barrancos, fendas em paredes, ninhos abandonados de aves, etc. (WILLE \& Michener 1973), e o tempo de construção de um novo ninho pode variar bastante. Para as espécies que nidificam em termiteiros ativos não há observações. Mas, neste caso, em que as abelhas possivelmente escavam o substrato e preparam toda a cavidade, o tempo de relações com o ninho parental pode ser muito mais extenso.

Os ninhos das espécies de Partamona, independentemente do tipo de substrato que utilizam (Tabela I), são constituídos de uma estrutura de entrada, com formas bastante variadas, como descrito mais adiante, uma câmara vestibular, preenchida por estruturas semelhantes a radículas anastomosadas, construídas de terra e resinas (esta estrutura é autapomórfica para o gênero) e uma ou mais câmaras de crias e potes de alimento. A comunicação entre o vestíbulo e a câmara de crias, usualmente é feita através de uma galeria (Figs. 8, 17, 24, 31, 45). O uso de terra cimentada com resinas, nas edificações do ninho, exceto nos favos, potes e lamelas, predomina em todas as espécies, mesmo naquelas que constróem ninhos livres, fixados em galhos de árvores ou outros substratos mais expostos, como é o caso de $P$. helleri.

Outra peculiaridade de Partamona, principalmente das espécies que constróem ninhos semi-expostos ou em termiteiros no interior de troncos e galhos de árvores (Tabela I), é que, na parte inferior da entrada, externamente ao substrato, mas comunicando-se com o vestíbulo, há, geralmente, um emaranhado de túbulos interligados, construídos de terra ou terra e resinas (Figs. 4, 19, 25-28, 31, 44) formando, às vezes, grandes massas que se confundem com o substrato (no caso deste ser termiteiro). A função destes túbulos é ainda desconhecida, mas quase sempre estão repletos de abelhas vivas; algumas vezes, também, observamos lixo no interior destes. Este caráter não foi incluído na análise filogenética. Das espécies conhecidas, somente P. testacea não apresenta 
Tabela I. Substratos utilizados pelas espécies de Partamona (dados originais e de literatura).

\begin{tabular}{|c|c|}
\hline Espécie & Substrato \\
\hline P. bilineata & $\begin{array}{l}\text { Sob pontes, galerias sob estradas, buracos e fendas em paredes de ruínas, cavidades de árvores } \\
\text { (RAU 1943; GONZÁLEs 1983-1984). }\end{array}$ \\
\hline P. grandipennis & Nidificação desconhecida. \\
\hline P. xanthogastra & Sob raízes de epífitas (RoubiK 1992). \\
\hline P. orizabaensis & $\begin{array}{l}\text { Cavidades no solo, entre os pecíolos de folhas de palmeiras, ninhos abandonados de aves, até } \\
\text { quase totalmente expostos (WILLE \& MichENER 1973); cavidade em ninho abandonado de térmita, } \\
\text { previamente ocupada por Scaura (WiLlE \& Orozco 1975). Âs vezes, em grandes agregações em } \\
\text { paredes de casas (Roubik, in litteris). }\end{array}$ \\
\hline P. peckolti & $\begin{array}{l}\text { Expostos sobre ramos de árvores, sob massas de raízes, em burados de barrancos, paredes, } \\
\text { beirais de casas, em grandes agregações em paredes de ruínas (RAU 1933; MichENER 1946; VILLA } \\
\text { \& VERGARA 1982; PARRA 1990; CoLOMA 1986; RouBIK 1983, 1992; Camargo, obs. pessoal). NATES- } \\
\text { PARRA \& CEPEDA (1983) indicam nidificação em termiteiros e formigueiros! Roubik (in litteris) } \\
\text { observou } 3 \text { ninhos em um termiteiro arborícola. }\end{array}$ \\
\hline P. aequatoriana & Sob raízes de epífitas (Coloma 1986). \\
\hline P. musarum & Em ninhos arborícolas abandonados de aves (WiLle \& Michener 1973). \\
\hline P. epiphytophila & $\begin{array}{l}\text { Sob raízes de epífitas, sob a base de folhas de palmeiras (Camargo et al., obs. pessoal), beirais de } \\
\text { telhados e outros lugares protegidos em edificações humanas (Oliveira, com. pessoal). }\end{array}$ \\
\hline P. yungarum & Nidificação desconhecida. \\
\hline P. subtilis & Nidificação desconhecida. \\
\hline P. vitae & Nidificação desconhecida. \\
\hline P. testacea & $\begin{array}{l}\text { Ninhos subterrâneos, em termiteiros (KERR et al. 1967; CAMARGo 1970, 1980) em ninhos de Atta } \\
\text { spp., e vários outros tipos de cavidades subterrâneas não associadas com ninhos de insetos } \\
\text { sociais (ScHWARz 1948; GonçALVEs 1973; CAMARGo } 1980 \text { e Camargo et al., obs. pessoal; Roubik, } \\
\text { in litteris). Hospedeiro identificado (ninho 55c): Syntermes spinosus (Latreille, 1804). }\end{array}$ \\
\hline P. mourei & $\begin{array}{l}\text { Em termiteiros arborícolas externos. Hospedeiro identificado: Amitermes excellens Silvestri, } 1923 \\
\text { (ninho 271c). }\end{array}$ \\
\hline P. vicina & $\begin{array}{l}\text { Em termiteiros arborícolas externos (CAMARGo 1980). SiLVESTRI (1902) refere-se a P. vicina (=T. } \\
\text { rhumbleri) em cavidade subterrânea (prov. equívoco). Hospedeiros identificados: Nasutitermes } \\
\text { cf. kenneri Snyder \& Emerson, } 1949 \text { (ninho 20c), Constrictotermes cyphergaster (Silvestri, } \\
\text { 1901) (ninho 21c), Constrictotermes cavifrons (Holmgren, 1910) (ninho 82c), Amitermes excellens } \\
\text { Silvestri, } 1923 \text { (ninhos 153c, 196c) e Nasutitermes cf. similis Emerson, } 1935 \text { (ninho 169c). }\end{array}$ \\
\hline P. nigrior & $\begin{array}{l}\text { Em parede de habitação humana (ScHwarz 1938); fixados em troncos de árvores, em Trinidad (B. } \\
\text { De Dijn, in litteris, 07.VI.1997). }\end{array}$ \\
\hline P. auripennis & $\begin{array}{l}\text { Em termiteiro arborícola externo (RouBIK } 1979=P \text {. cupira, Camargo, obs. pessoal). De acordo } \\
\text { com Bart De Dijn (in litteris, 07.VI.1997), em termiteiro arborícola, parede de casas e ninho } \\
\text { abandonado de aves (P. auripennis ?). }\end{array}$ \\
\hline P. combinata & $\begin{array}{l}\text { Em termiteiros arborícolas externos. Hospedeiros identificados: Nasutitermes cf. kenneri Snyder } \\
\text { \& Emerson, } 1949 \text { (ninho 37c). Microcerotermes cf. strunki (Sorensen, 1884) (ninho 52c) e } \\
\text { Microcerotermes spp. (ninhos 53c e 500c). }\end{array}$ \\
\hline P. chapadicola & Em termiteiros em ocos de troncos e galhos de árvores vivas ou mortas. \\
\hline P. nhambiquara & $\begin{array}{l}\text { Em oco de árvore, associado com termiteiros (M. L. Oliveira; G. G. Azevedo e S. Mateus, com. } \\
\text { pessoal). }\end{array}$ \\
\hline P. ferreirai & $\begin{array}{l}\text { Em termiteiros em ocos de troncos e galhos de árvores vivas ou mortas. Hospedeiro identificado: } \\
\text { Termes cf. hispaniolae (Banks, 1918) (ninho 252c). }\end{array}$ \\
\hline P. pearsoni & $\begin{array}{l}\text { Em termiteiros arborícolas externos. Hospedeiro identificado: Nasutitermes cf. peruanus (Holmgren, } \\
\text { 1910) (ninhos 222c, 245c, 249c) e Amitermes excellens Silvetri, } 1923 \text { (ninho 292c). B. De Dijn (in } \\
\text { litteris, 07.VI.1997) observou ninhos em cavidades de árvores. }\end{array}$ \\
\hline
\end{tabular}


Tabela I. (continuação)

\begin{tabular}{|c|c|}
\hline Espécie & Substrato \\
\hline P. gregaria & $\begin{array}{l}\text { Em termiteiros arborícolas externos - do tipo estróbilo, principalmente. Hospedeiros identificados: } \\
\text { Nasutitermes cf. tatarendae (Holmgren, 1910) (agregação de ninhos 115c-120c). Nasutitermes } \\
\text { acangussu Bandeira \& Fontes, } 1979 \text { (ninhos 194c, 195c), Amitermes excellens Silvestri, } 1923 \\
\text { (ninhos 146c, 147c). }\end{array}$ \\
\hline P. batesi & $\begin{array}{l}\text { Em termiteiro arborícola externo, do tipo cartonado, principalmente. Hospedeiro identificado: } \\
\text { Nasutitermes acangussu Bandeira \& Fontes, } 1979 \text { (ninhos 522c, 526c e 570c) e outras espécies de } \\
\text { Nasutitermes. }\end{array}$ \\
\hline P. ailyae & $\begin{array}{l}\text { Em termiteiros em tocos de árvores secas ou podres, em termiteiros no interior da base de troncos } \\
\text { de árvores vivas, em termiteiros epígeos, em termiteiros subterrâneos. Hospedeiros identificados: } \\
\text { Syntermes molestus (Burmeister, 1839) (ninhos 6c e 505c), Termes cf. medioculatus Emerson, } 1925 \\
\text { (ninhos 148c, 575c). }\end{array}$ \\
\hline P. sooretamae & Nidificação desconhecida. \\
\hline P. cupira & Em termiteiros epígeos (Peckolt, 1894 in IHERING 1903, 1930; MARIANNO 1911, Camargo, obs. pessoal). \\
\hline P. mulata & $\begin{array}{l}\text { No solo e em troncos de árvores (SILVESTRI 1902); em termiteiros epígeos (G. Melo e R. Ribon, com. } \\
\text { pessoal); termiteiros em troncos e ocos de árvores (R. Ribon, com. pessoal). }\end{array}$ \\
\hline P. seridoensi & $\begin{array}{l}\text { Em termiteiros arborícolas externos, de terra. Hospedeiro identificado: Constrictotermes sp. } \\
\text { (LoRENZON et al., 1999). }\end{array}$ \\
\hline P. criptica & Em termiteiro no interior de tronco de árvore (I. Stanciola, com. pessoal). \\
\hline P. rustica & $\begin{array}{l}\text { Termiteiro arborícola externo e cumeeira de habitação humana (M. Mazucato e G. Melo, com. } \\
\text { pessoal). }\end{array}$ \\
\hline P. littoralis & Nidificação desconhecida. \\
\hline P. helleri & $\begin{array}{l}\text { Sob raízes de epífitas (IHERING 1903, 1930; MARIANNo 1911; DuCKE 1916; Camargo \& Pedro, obs. } \\
\text { pessoal), buracos em paredes, beirais e cumeeiras de casas, sob aparelhos de ar condicionado, } \\
\text { ninhos abandonados de aves, livres sobre galhos de árvores, enfim, em qualquer substrato que } \\
\text { apresente alguma proteção. Em termiteiros ativos (F. Silveira, com. pessoal). }\end{array}$ \\
\hline
\end{tabular}

essas estruturas; em $P$. vicina, $P$. mourei, $P$. mulata e $P$. cupira, alguns túbulos podem existir pelo menos em algumas fases da construção do ninho.

A população dos ninhos de Partamona varia, aproximadamente, entre 1.000 e 3.000 indivíduos adultos (Michener 1946: 192 e observações pessoais). Os ninhos de $P$. vicina estão entre os maiores e mais populosos, e os de $P$. batesi, entre os menores, às vezes com menos de 1.000 indivíduos. As realeiras são construídas na periferia dos favos - é comum encontrá-las fixadas no invólucro (Fig. 45), depois que os favos são destruídos, após as demais abelhas terem emergido.

Adiante, para efeito de delimitação e codificação dos caracteres, e de discussão sobre seu significado na história do grupo, são apresentados, separadamente, cada componente principal do ninho: substrato, estrutura de entrada, câmaras vestibulares, galerias e câmara de crias e alimento.

Dados sobre o comportamento de defesa das operárias não foram incluídos visto que todas as espécies cujos hábitos são conhecidos, são igualmente agressivas - mordem e perseguem o intruso.

\section{Substrato de Nidificação \\ (Caracteres 1, 2; Tabelas I, II)}

De Parapartamona, principal candidato a grupo irmão de Partamona, são conhecidos ninhos apenas de $P$. vittigera e de $P$. tungurahuana. Ambas nidificam em uma variedade de substratos: sob musgos e raízes de samambaias em montículos no solo, barrancos junto a raízes de árvores, sob raízes de epífitas, fendas em construções humanas, como casas, muros e pontes (Roubik, in litteris, relata que observou 3 ninhos de $P$. vittigera em ocos de árvores, na região de Santo Domingo de los Colorados, Equador, $2100 \mathrm{~m}$ ). Em nenhum dos casos conhecidos há qualquer indício de associação com ninhos de térmitas. Ecologicamente, Parapartamona está bem isolada de Partamona; é endêmica dos bosques úmidos, entre 1500 e $2700 \mathrm{~m}$ de altitude, das encostas andinas ocidentais e orientais, do sul do Equador até o norte da Colômbia (Coloma 1986; Bravo 1992; GonçÁlez-B \& NATEs-PARRA 1999; Camargo, obs. pessoal). As espécies de Partamona chegam a 1500-1600 m de altitude nas encostas andinas e apenas ocasionalmente até 2000 m (Pedro \& Camargo 2003). 
Pelo critério de grupo externo, há pouca ambigüidade com relação à direção evolutiva desse caráter. Todas as espécies de Partamona que ocorrem no lado oeste dos Andes (no Equador e Colômbia) e no Panamá, América Central e México, nidificam em substratos semelhantes ou equivalentes àqueles de Parapartamona, exceto $P$. grandipennis, cujos hábitos não são conhecidos (Tabela I). Partamona peckolti, $P$. orizabaensis, $P$. xanthogastra, $P$. bilineata, $P$. aequatoriana e $P$. musarum nidificam sob raízes de epífitas, buracos e fendas em paredes, cavidades no solo, entre a base de folhas de palmeiras, ninhos abandonados de aves, etc. (Tabela I; RAU 1943; Wille \& Michener 1973; Wille \& Orozco 1975; Villa \& Vergara 1982; NAtes-ParRa 1983; GonZÁlez 1983-1984; Coloma 1986; Parra 1990; RoubiK 1992). Apenas P. peckolti eventualmente nidifica em termiteiros ativos (Roubik in litteris).

Na América do Sul, a leste dos Andes, das espécies cujos hábitos são conhecidos, somente $P$. epiphytophila, endêmica do oeste da Amazônia (Fig. 49), nidifica, como o nome indica, principalmente sob raízes de epífitas (Figs. 3, 4), e P. helleri, do sudeste do Brasil (Fig. 54), que utiliza, além de raízes de epífitas (Fig. 46), também uma variedade de outros substratos, como beirais de casas (Fig. 47), buracos em paredes, etc. (Tabela I), e eventualmente termiteiros arborícolas ativos (população da região de Paraopeba, MG).

Todas as demais espécies da América do Sul (exceto $P$. nigrior, $P$. subtilis, $P$. yungarum, $P$. littoralis, $P$. sooretamae e $P$. vitae, cujos hábitos não são conhecidos) são termitófilas nidificam no interior de termiteiros hipógeos, epígeos ou arborícolas, ativos: P. batesi (Fig. 33), P. vicina (Figs. 3, 14, 15, 17, 32), P. pearsoni (Figs. 30, 31), P. gregaria (Fig. 32), P. mourei (Figs. 10, 11), P. ferreirai (Fig. 27), P. auripennis (Figs. 18, 19), P. nhambiquara (Fig. 26), P. combinata (Fig. 23), P. chapadicola (Fig. 25), P. seridoensis (Fig. 20), P. mulata (Figs. 48), P. cupira (Fig. 45), P. criptica (Fig. 43), P. rustica e P. ailyae (Figs. 3, 3740; Tabela I). Partamona testacea constrói ninhos subterrâneos, facultativamente em termiteiros e em ninhos de Atta spp., ativos (Figs. 3, 5-8), ou em outras cavidades subterrâneas não-associadas com ninhos de insetos sociais (Tabela I).

Para algumas espécies com endemismo muito restrito, como no caso de $P$. pearsoni, $P$. ferreirai, $P$. batesi e $P$. gregaria, há indícios de preferências por certos tipos de termiteiros, que estão limitados às respectivas áreas de distribuição das espécies de Partamona que os habitam. Estes casos são fortes indícios de coevolução biogeográfica, hóspede-hospedeiro.

Procedemos duas codificações para este caráter, que foram testadas em conjunto e separadamente. Na primeira, consideramos apenas dois estados - associação e não associação com termiteiros. Na segunda, codificamos os principais tipos de substratos, considerando a associação com os diversos tipos de termiteiros: ninhos subterrâneos facultativamente associados com termiteiros (Figs. 3, 5-8; $P$. testacea é a única espécie que constrói ninhos subterrâneos, obrigatórios); ninhos associados com termiteiros epígeos (do tipo “murundu”, de terra; Figs. 40, 45, 48) e aqueles construídos na base de troncos podres ou vivos (Figs. 37-39) e ninhos associados com termiteiros arborícolas externos. Há uma grande variedade de tipos de termiteiros arborícolas incluídos neste último item: de terra, do tipo "bola", usualmente apoiados sobre curvaturas de troncos de árvores, comuns nos cerrados do Brasil Central (Figs. 15, 20); pendurados em galhos ou fixados em troncos de árvores, do tipo Constrictotermes cavifrons (Holmgren, 1910) da Amazônia (Fig. 3); do tipo estróbilo, anexados em grandes extensões de troncos de árvores, também comuns nas paredes de construções humanas na região do médio rio Tapajós (Figs. 10, 11, 32); do tipo cartonado, pretos, construídos com matéria húmica e proctodeica (Figs. 30, 33). Como um estado diferente, foram tratados os ninhos associados com termiteiros arborícolas no interior de troncos de árvores (Figs. 25-27).

\section{Estrutura de Entrada \\ (Caracteres 3-10; Tabela II)}

Em contraste com a homogeneidade morfológica dos machos e operárias de diferentes espécies de Partamona (PEDRO \& CAMARGo 2003), o que resulta na impraticabilidade de se reconhecer algumas delas, as estruturas de entrada variam na forma, cor, ornamentação e composição dos materiais utilizados, sendo, praticamente, peculiares a cada espécie (Figs. 1, 2). Há poucas delas cujo padrão deixa dúvidas quanto à identidade.

Com relação à forma, no plano básico, a estrutura de entrada dos ninhos de Partamona é constituída de uma abertura em forma de concha acústica, com uma rampa inferior por onde as abelhas alçam vôo, e uma rampa superior ou contra-rampa, em forma de abóbada, para pouso. Nas espécies conhecidas de Parapartamona, a entrada é em forma de funil ou trompete (Fig. 1a), não havendo rampas distintas para pouso e decolagem. Outra diferença é que, em Parapartamona, o funil de entrada é constituído, basicamente, de resinas muito endurecidas e compactas (Coloma 1986; Bravo 1993; Camargo, obs. pessoal); só na margem do rebordo há uma mistura de terra, partículas vegetais e musgo, que cresce ao redor. Em Partamona, a entrada é constituída basicamente de terra cimentada com resinas vegetais; em algumas espécies, entretanto, a entrada é basicamente de terra, consolidada, provavelmente, com líquidos de origem intestinal das abelhas (CAMARGO 1980). Nos demais grupos externos considerados por PEDRo \& CAMARgo (2003), como Plebeia, Nannotrigona, Scaptotrigona, Nogueirapis e Meliwillea, a entrada é constituída de um tubo de cerume (cera e resinas), sem rampas distintas para pouso e decolagem.

Sobre este plano básico da estrutura de entrada, há uma larga diversidade de adereços, ou inovações evolutivas (Figs. 1,2 ), não só com relação às especializações das rampas de pouso e decolagem mas, particularmente, com relação à orientação de pouso. Em algumas espécies (P. pearsoni, $P$. batesi e P. gregaria, por exemplo) são ricamente ornamentadas e revestidas com fina película de argila cinza-gelo (Figs. 30, 3236), em forte contraste com o substrato, constituindo-se em verdadeiros alvos de orientação para pouso (СнітткA et al. 1997). As abelhas voam, em linha reta, desde uma certa distância da entrada (1,0 m ou mais) e, literalmente, chocam-se contra a 
rampa superior (contra-rampa) e deslizam para dentro do funil até o orifício de entrada. Em P. pearsoni, há ondulações ou estrias transversais na contra-rampa, que suavizam a queda das campeiras em direção ao orifício de comunicação com o vestíbulo (Figs. 2g, 30, 31, 36). Tanto P. gregaria como P. batesi são espécies que nidificam em grandes agregações, em um mesmo termiteiro (Figs. 32, 33), estando as entradas, às vezes, muito próximas umas das outras e, neste caso, os diferentes ornamentos, supostamente, têm função no reconhecimento do ninho.

Em muitas espécies, entretanto, principalmente aquelas que constróem ninhos solitários, as entradas não são tão conspícuas em relação ao substrato; não há revestimento contrastante nem ornamentos complexos. Apenas algumas delas (P. ailyae, $P$. cupira, $P$. criptica e $P$. seridoensis, por exemplo) constróem estrias longitudinais no rebordo da rampa inferior (Figs. 1g, 21, 37-41, 43); outras (P. vicina e P. mourei) constróem estrias ao redor de todo o rebordo (Figs. 1e-f, 9, 12, $13,16)$.

O formato das rampas também varia bastante (Figs. 1, 2). Em algumas espécies (P. ailyae e $P$. ferreirai, por exemplo), a rampa inferior é horizontal e a superior em abóbada normal, de modo que a entrada, vista de frente, tem a forma aproximada de um triângulo equilátero (Figs. 1g, 2a-b, 28, 29, 41-44). Em outras espécies, como $P$. batesi, $P$. gregaria e $P$. pearsoni, a rampa inferior é praticamente vertical e a abóbada em declive, de modo que a entrada adquire uma forma ovalada, ou elipsóide muito estreita (Figs. 2e-g, 34-36).

Diante dessa diversidade de formas, torna-se difícil delimitar atributos que possam constituir caracteres discretos e informativos filogeneticamente; some-se a isso, ainda, os vícios adquiridos no trabalho de campo, quando se observa as estruturas em seu conjunto, mais para efeito diagnóstico do que para inferir relações. Alguns atributos que supostamente estão combinados, como um único evento evolutivo, podem ter tido surgimentos independentes. Por outro lado, essas estruturas, ou obras, são produtos do comportamento e podem apresentar variações dentro de uma mesma espécie. Portanto, o delineamento de padrões básicos que possam sugerir ou indicar aquisições comportamentais distintas, passíveis de codificação e análise cladística, é difícil ou, no mínimo, ambíguo.

Consideramos, com relação à estrutura de entrada, oito caracteres, conforme descritos abaixo (caracteres 3 - 10).

\section{Forma da entrada (caracteres 3-8, Tabela II)}

Vista frontal (caráter 3). Em Parapartamona, a entrada em vista frontal é circular, em forma de trompete. Em Partamona não há nenhuma espécie que apresente a entrada com essas características; todas obedecem a um desenho básico triangular, desde um triângulo aproximadamente equilátero, de cantos e lados arredondados, até triângulos isósceles ou elipsóides muito alongados para cima (Figs. 1, 2). Para codificar as espécies em um ou outro dos estados (Tabela II), foram consideradas as formas mais gerais e mais constantes para cada uma delas.

Vista de perfil (caráter 4). Os estados do caráter delineados na Tabela II, não permitem descrever de maneira clara e sem ambigüidades todos os padrões de concha de entrada encontrados em Partamona; em alguns casos são intermediários ou de difícil avaliação. A única espécie de Partamona que, às vezes, apresenta as rampas formando um cilindro afunilado, com alguma semelhança com o grupo externo, é $P$. testacea, porém este é fortemente encurvado para baixo (Figs. 1d, 6-8) e o consideramos em um estado diferente. Com a rampa inferior praticamente na vertical e a abóbada, ou contrarampa, em forte declive (estado 3), podem ser inscritas $P$. pearsoni, $P$. gregaria, $P$. batesi, $P$. chapadicola e $P$. nhambiquara (Figs. 2c-g).

Rebordo (caráter 5). Dentre os vários tipos de rebordo (Figs. 1e-g, 2c-g), há aqueles em que apenas a rampa inferior é suavemente revirada, até aqueles em que se forma uma forte quina entre o rebordo e a margem da concha. Em algumas entradas de $P$. mourei, não se distingue claramente a rampa de pouso do rebordo. Este é um caráter fortemente ambíguo e foi codificado em cinco estados (Tabela II).

Estriação (caráter 6). Estrias são sulcos longitudinais no rebordo inferior ou nas rampas inferior e superior (Figs. 1e-g). Em Parapartamona, a superfície do funil de entrada é lisa e polida, não há qualquer estriação (Fig. 1a). Nesse estado, podem ser inscritas as espécies que apresentam as rampas lisas e a margem externa do funil truncada ou apenas crenulada: $P$. epiphytophila, P. peckolti (Coloma 1986), P. orizabaensis ( $=$ T. cupira de Wille \& Michener 1973), P. bilineata (RAu 1943), $P$. aequatoriana (Coloma 1986), P. musarum (Wille \& MicheneR 1973), P. testacea, P. auripennis, P. combinata e P. helleri (Figs. 1b-d, 1h). São incluídas ainda, nesse estado, aquelas espécies que apresentam as rampas lisas e polidas ou as rampas alveoladas, mas não estriadas, porém com o rebordo ornamentado com estruturas semelhantes a radículas (ver caráter 8: P. pearsoni, P. gregaria, P. batesi, P. chapadicola e P. nhambiquara, (Figs. 2c-g). Com o rebordo inferior estriado ou sulcado longitudinalmente (estado 1), e com a margem do rebordo crenulada, as seguintes espécies podem ser inscritas, embora, às vezes, os sulcos não sejam muito nítidos: $P$. criptica, P. mulata, P. cupira, P. ailyae e P. seridoensis (Figs. 1b-d, 1g-h, 21, 41-43).

Nos ninhos de $P$. ferreirai da região do rio Trombetas, AM, a margem da estrutura de entrada é truncada ou muito estreita e não forma estrias; porém, nos ninhos da região do rio Negro pode haver um pequeno rebordo inferior, às vezes, com pequenas estrias (Figs. 2a-b), mas não comparável com a entrada de P. ailyae, por exemplo. Estrias profundas ao redor de todo o rebordo e prolongando-se ao longo da superfície do funil de entrada (estado 2), ocorrem apenas em $P$. vicina e $P$. mourei (Figs. 1e-f, 9, 12, 13, 16). Nesta última, as estrias são bastante irregulares e entremeadas por sulcos transversais (Fig. 9).

Alvéolos (caráter 7). Em P. ferreirai, a superfície da contrarampa ou abóbada é profundamente alveolada (Figs. 2a-b, 28, 29); os alvéolos, irregulares e profundos (até $1,0 \mathrm{~cm}$ ou mais de diâmetro e, em alguns casos, com 2,0 cm ou mais de profundidade), são distribuídos aleatoriamente. Em $P$. 
nhambiquara os alvéolos são, também, bem conspícuos (Figs. 2d, 26), porém em $P$. chapadicola, geralmente estão limitados ao rebordo e, às vezes, bem esparsos (Fig. 2c). Em $P$. batesi e $P$. gregaria os alvéolos estão situados na base das estruturas radiculares que ornamentam o rebordo da entrada (Figs. 2c-f, 34-35). Nas demais espécies não há estruturas comparáveis, apenas em $P$. helleri são, ocasionalmente, encontrados alguns alvéolos na contra-rampa (Figs. 1c, 44).

Ornamentação radicular (caráter 8). Projeções em forma de radículas anastomosadas, ao redor do rebordo (estado 2), ocorrem em P. batesi, P. gregaria e P. pearsoni (Figs. 2e-g, 3436). Em P. nhambiquara e pelo menos em uma das entradas de $P$. chapadicola, o rebordo é ornamentado com desenhos semelhantes a radículas (estado 1), porém não projetadas como nas espécies acima (Figs. 2c-d). Das dezenas de ninhos de $P$. ferreirai estudados, apenas a entrada de um deles apresentava o rebordo com desenhos do tipo radicular. Todas as demais espécies são desprovidas de tais ornamentos.

\section{Materiais utilizados na construção da estrutura da entrada (caráter 9, Tabela II)}

As entradas das espécies conhecidas de Parapartamona, são construídas basicamente com resinas, enquanto que as espécies de Partamona utilizam terra cimentada com resinas, em proporções muito variáveis. Há espécies que utilizam principalmente terra, onde a resina está praticamente ausente ou apenas em pequenas proporções, e há aquelas que utilizam muito mais resinas do que terra, de modo que a superfície da entrada fica preta e até brilhante, como em algumas entradas de P. epiphytophila, por exemplo; mas nenhuma das espécies conhecidas utiliza resina pura, como em Parapartamona.

Entrada de terra praticamente pura ou cimentada com algum líquido incolor, só conhecemos em $P$. mourei (Figs. 9, 12). Em $P$. vicina (Figs. 13, 16) e P. testacea (Figs. 6, 7), algumas entradas são de terra praticamente pura, enquanto que, em outras, há aplicações de resinas próximo à base do funil de entrada.

\section{Revestimento da estrutura de entrada (caráter 10, Tabela II)}

Em P. gregaria, P. pearsoni e P. batesi, a estrutura de entrada é construída com uma mistura de terra e resinas (mais resinas do que terra), mas com um fino revestimento de argila cinzaclaro em toda a superfície do rebordo e rampas (Figs. 34-36); apenas em $P$. batesi o revestimento não atinge a rampa de pouso, que é de resinas enegrecidas, em forte contraste com o restante da estrutura. Esse revestimento é aplicado sobre a base de resinas, formando uma fina película que mais se assemelha a uma pintura feita à cal, muito macia ao tato e que, quando molhada, exala cheiro de moringa nova, típico da argila. A confecção desse revestimento possivelmente envolve um comportamento distinto de seleção de material, onde só argila pura, de cor clara, é coletada, enquanto que para moldar toda a estrutura é utilizada terra de granulação grosseira cimentada com resinas (veja item "Estrutura de Entrada”).

Em P. ferreirai, nem todas as entradas recebem um revestimento de argila tão denso como aquele de $P$. batesi, porém é nítido que há um revestimento. Em $P$. nhambiquara e
P. chapadicola o revestimento é um pouco mais rústico e menos conspícuo que em $P$. batesi. Em $P$. chapadicola, às vezes, o revestimento é de cor salmão, o que, provavelmente, está relacionado com o tipo de argila disponível no local.

\section{Câmaras Vestibulares \\ (Caracteres 11, 12, 13; Tabela II)}

Em Parapartamona, a entrada do ninho termina diretamente sobre o invólucro da câmara de crias; não há câmaras ou galerias intermediárias. Em Partamona, o orifício de entrada abre-se em uma larga câmara que antecede a câmara de crias, a qual denominamos vestíbulo (KerR et al. 1967; CAMARGo 1970, 1980). A câmara vestibular, uma autapomorfia de Partamona, é preenchida por estruturas semelhantes a radículas anastomosadas, construídas com terra e resinas e que, usualmente, terminam na forma de um cone justaposto ao orifício de entrada (Figs. 8, 17, 24, 31, 45). Em algumas espécies, como em P. pearsoni (Fig. 31), P. ferreirai e P. testacea (Fig. 8), por exemplo, as radículas são relativamente de pequeno calibre (0,3-0,5 cm de diâmetro), enegrecidas e formando uma trama cerrada, fortemente anastomosadas, porém, toda a estrutura delicadamente presa às paredes da câmara por finos conectivos, de maneira que é facilmente destacável, sem danos. Em $P$. combinata, as radículas são grossas $(1,0-2,0 \mathrm{~cm}$, ou mais, de diâmetro) e fortemente ligadas às paredes do vestíbulo (Fig. 24). Em P. vicina (Fig. 17), P. mourei e P. mulata, as radículas são constituídas basicamente de terra obtida do termiteiro onde se hospedam; são da mesma cor que este e, às vezes, constituindo largas placas compactas.

O vestíbulo pode ser constituído de uma câmara irregular, dando acesso à câmara de crias através de curta e larga galeria, ou de uma câmara bem delineada, dando acesso à câmara de crias através de uma estreita e longa galeria (como em P. testacea - Fig. 8, P. vicina -Fig. 17, P. mourei e P. ailyae, por exemplo), iniciando-se, em algumas espécies, em um orifício de pequeno calibre (0,7-0,8 cm), na parede posterior do vestíbulo. Em $P$. epiphytophila, $P$. gregaria, $P$. batesi, $P$. pearsoni, $P$. ferreirai e P. peckolti (Roubik, in litteris) a galeria de acesso à câmara de crias inicia-se em uma projeção em forma de gargalo de garrafa (Fig. 31). Em P. helleri também há um gargalo, porém menos conspícuo.

Outra peculiaridade do vestíbulo é que, na maioria das espécies cujos ninhos são conhecidos, há, fixados nas radículas ou em câmaras anexas, algumas finas lamelas cerosas e/ou pequenos potes (menores que aqueles usados para armazenamento, anexos à câmara de cria; Figs. 8, 17, 24, 31, 45); estes, porém, vazios ou com uma substância ácida aquosa, ou eventualmente com algum pólen e mel.

Em P. vicina, há uma segunda câmara ou átrio (Fig. 17), usualmente na parte superior do vestíbulo, e com o qual se comunica por meio de curta galeria (CAMARGo 1980). Esta câmara é preenchida por lamelas cerosas semelhantes ao invólucro de crias, alvéolos de crias e pequenos potes distribuídos irregularmente (Fig. 17), todos vazios ou com substância ácida aquosa. Um orifício de 0,7-0,8 cm na parte inferior do átrio dá 
Tabela II. Caracteres das espécies de Partamona utilizados nas hipóteses de filogenia (Figs. 57-58; Tabela III). Caracteres 01-15 referem-se aos dados de ninhos, e 16-29 aos de cor e forma das abelhas, conforme Pedro \& Camargo (2003).

1) Substrato de nidificação I

0. ninhos não-associados com termiteiros, ou apenas facultativamente associados (Figs. 4, 46, 47)

1. ninhos associados com termiteiros

2) Substrato de nidificação II

0. ninhos subterrâneos, associados com termiteiros, formigueiros ou em cavidades abandonadas (Figs. 3, 5, 8)

1. associados com termiteiros epígeos (Figs. 40, 45, 48)

2. associados com termiteiros arborícolas externos (Figs. 3, 10, 11, 14, 15, 17-20, 23, 24, 30-33)

3. associados com termiteiros arborícolas no interior de galhos e troncos (Figs. 25-27, 43)

3) Forma da entrada, vista frontal

0 . aproximadamente circular, em forma de trompete (Fig. 1a)

1. aproximadamente em triângulo equilátero, com os cantos e lados arredondados ou arredondada-ovalada (Figs. 1b-h, 2a-b, 6, 7, 9, 12, $13,16,21,22,28,29,41-44)$

2. ovalada-alongada ou em triângulo isósceles, a altura cerca de duas vezes, ou mais, maior que a largura; a contra-rampa muito ampliada verticalmente (Figs. 2c-g, 25, 26, 33-36)

4) Forma da entrada, em corte de perfil

0. em forma de funil, cilíndrico, aproximadamente horizontal; as paredes afunilando-se, gradualmente, até formar o orifício de comunicação com o ninho (Fig. 1a)

1. aproximadamente em forma de concha acústica, com a rampa inferior plana, ou inclinada-convexa para dentro, em direção ao orifício de entrada, em um ângulo de até $45^{\circ}$ aproximadamente (Figs. 1b-c,g, 2a-b)

2. em forma de funil encurvado, a rampa inferior fortemente convexa (Figs. 1d-f)

3. aproximadamente em forma de colher profunda, a rampa inferior e a contra-rampa formando uma única superfície côncava (Fig. 1h)

4. aproximadamente em forma de funil vertical, a rampa inferior muito inclinada para dentro, ca. de $70^{\circ}$ ou mais, de modo que o funil que conduz ao orifício de entrada, fica bastante profundo e aproximadamente na vertical (Figs. 2c-g)

5) Entrada do ninho, rebordo

0 . com rebordo revirado, ao redor de toda a entrada, em forma de trompete (Figs. 1a,e,f, 9, 12, 13, 16)

1. rebordo látero-inferior estreito, convexo, levemente revirado (Figs. 1c, 44)

2. rebordos laterais e principalmente o inferior, amplos, convexos, revirados (Figs. 1g, 28, 41, 42, 43)

3. sem rebordo (Figs. 1b,d,h, 22)

4. com rebordo amplo, revirado em ângulo agudo (Figs. 2c-g, 25, 26, 34-36)

6) Entrada do ninho, estriação

0. sem estrias ou com a margem crenulada (Figs. 1a-d, 1h, 2a-g, 6, 7, 22, 25, 29, 34-36)

1. com estrias longitudinais no rebordo látero-inferior (Figs. 1g, 21, 41-43)

2. com estrias distribuídas radialmente em todo o rebordo, prolongando-se pela rampa e contra-rampa (Figs. 1e-f, 9, 12, 13, 16)

7) Entrada do ninho, alvéolos

0. ausentes (Figs. 1a-h, 2g, 6, 7, 9, 12, 13, 16, 21, 22, 36, 41-44)

1. com alguns alvéolos ao redor do rebordo (Figs. 2c-f, 26, 34-35)

2. com muitos alvéolos no rebordo e contra-rampa (Figs. 2a-b, 27-29)

8) Entrada do ninho, ornamentação radicular

0. ausente (Figs. 1a-h, 2a-b, 6, 7, 9, 12, 13, 16, 21, 22, 41-44)

1. com estruturas radiculares, não projetadas, acompanhando a margem do rebordo (Figs. 2c-d, 25, 28)

2. com estruturas radiculares, fortemente projetadas, acompanhando a margem do rebordo (Figs. 2e-g, 34-36)

9) Material utilizado na construção da entrada

0 . resinas (incorpora partículas vegetais e alguns grãos de quartzo do próprio substrato)

1. resinas e terra (predominantemente resinas)

2. terra e resinas (predominantemente terra)

10) Estrutura de entrada com fino revestimento de argila, principalmente no rebordo, usualmente de cor cinza-gelo ou salmão

0. ausente (Figs. 1a-h, 6, 7, 9, 12, 13, 16, 21, 22, 41-44)

1. presente (Figs. 2a-g, 25, 26, 28-30, 33-36)

11) Câmaras vestibulares

0 . ausentes

1. uma câmara (Figs. 8, 24, 31, 45)

2. duas ou mais câmaras (Fig. 17)

12) Comunicação entre a entrada e a câmara de crias

0. direta, o tubo de entrada termina diretamente na câmara de crias (não há vestíbulo)

1. através de galeria, que se inicia em um orifício simples, na parede posterior ou inferior do vestíbulo (Figs. 8, 24, 45), ou a partir do átrio (Fig. 17)

2. através de galeria que se inicia em pequeno tubo, em forma de gargalo de garrafa, na parede posterior do vestíbulo (Fig. 31)

13) Materiais utilizados na construção das radículas do vestíbulo

0 . terra, basicamente

1. terra e resinas 
Tabela II. (continuação)

14) Câmara de crias e alimento

0. uma câmara contendo crias e alimento (Figs. 8, 24, 31, 45)

1. uma câmara de crias e alimento, e uma ou mais câmaras acessórias com potes de alimento (Fig. 17)

15) Sustentação dos favos de crias e potes

0 . pilares e conectivos de cerume

1. pilares de terra e resinas, permanentes (Figs. 8, 17, 24, 31, 45)

16) Cor do tegumento, cabeça e tórax

0 . preto

1. amarelo

17) Mandíbula - comprimento dos dentes em relação ao bordo laminar distal da mandíbula

0 . o ápice dos dentes aproximadamente no nível do bordo

1. dentes um pouco recuados em relação ao bordo

2. dentes muito recuados em relação ao bordo

18) Mandíbula - espaçamento dos dentes

0 . o espaço entre os dentes aproximadamente igual ao espaço entre o dente médio e o ápice interno do bordo distal da mandíbula

1. o espaço entre os dentes, em arco largo e profundo, maior que o espaço entre o ápice do dente médio e o ápice interno do bordo distal da mandíbula

19) Comprimento da área malar

0 . longa (ca. $1,5 \mathrm{x}$ o diâmetro do $2^{\circ}$ flagelômero, ou mais longa)

1. aproximadamente tão longa quanto o diâmetro do $2^{\circ}$ flagelômero $(0,9-1,2 x)$

2. área malar curta (ca. 0,8x mais curta que o diâmetro do $2^{\circ}$ flagelômero)

20) Comprimento da asa anterior em relação à largura máxima da cabeça

0 . longa (ca. 3,0x ou mais longa que a largura máxima da cabeça)

1. normal (ca. 2,0-2,6x mais longa que a largura máxima da cabeça)

21) Distância interocelar em relação à ocelorbital

0 . menor ou igual

1. maior

22) Cor das veias alares

0 . méleas ou ferrugíneas, uniformemente escurecidas, ou somente C e R mais escuras em direção à base da asa

1. méleo-claras ou amarelas

2. ferrugíneo-escuras, exceto o pterostigma amarelado

23) Cor do labro

0 . amarelado

1. enegrecido

24) Reflexo violeta no clípeo e áreas paroculares inferiores

0 . ausente

1. presente

25) Manchas no clípeo

0. uma única mancha, mais ou menos difusa, no meio ou em todo o clípeo

1. duas manchas contrapostas, triangulares ou em L, próximas uma da outra, a distância entre elas aproximadamente igual ao diâmetro do $2^{\circ}$ flagelômero

2. duas manhas contrapostas, triangulares, mais ou menos difusas e afastadas uma da outra por uma distância maior que o diâmetro do $2^{\circ}$ flagelômero

26) Basitarso III do macho

0. achatado ou convexo-côncavo

1. um pouco intumescido

2. fortemente intumescido

27) Projeção mediana do EVII do macho

0 . triangular, larga na base, chanfros laterais rasos

1. com lados subparalelos, ou triangular, estreita na base, chanfros laterais profundos

28) Forma do basitarso III do macho

0 . alongado

1. curto e largo

29) Basitarso III da operária

0 . de lados subparalelos

1. com a margem posterior fortemente sinuada, a maior largura próxima do ápice 
acesso à galeria de comunicação com a câmara de crias. Também na parte inferior do vestíbulo dos ninhos de $P$. vicina, sempre há algumas lamelas cerosas e pequenos potes (Fig. 17). Em $P$. mourei há, às vezes, duas ou três pequenas câmaras associadas ao vestíbulo e antecedendo a galeria de comunicação com a câmara de crias, mas geralmente contendo apenas pequenos potes com substância aquosa ácida; não observamos, em nenhum dos ninhos estudados, lamelas cerosas e alvéolos de crias vazios.

A diversidade de forma, conteúdo e número de câmaras associadas ao vestíbulo, permite presumir seu alto significado seletivo relacionado ao sistema de defesa do ninho. Quando apenas os ninhos de P. testacea eram conhecidos em detalhes, KERR (1969) e CAMARGo (1970) aventaram a hipótese de que o vestíbulo poderia constituir um ninho falso, "funcionando" como defesa contra grandes predadores - como iraras, tamanduás e tatus (no caso específico de $P$. testacea, cujos ninhos são subterrâneos). Tal hipótese tem pouca sustentação, visto que predadores desse porte podem destruir, facilmente, todo o ninho, e um pequeno vestíbulo junto à entrada não constitui empecilho. Todavia, há poucas dúvidas de que o vestíbulo tenha significado na defesa contra outros insetos, especialmente insetos sociais cleptobióticos, como as espécies do gênero Lestrimelitta. Em várias ocasiões tivemos oportunidade de observar ataques de Lestrimelitta a ninhos de Partamona. Em um dos casos, observado em um ninho de $P$. vicina, às margens do rio Ipixuna, AM, Brasil $\left(63^{\circ} 20^{\prime} \mathrm{W}\right.$, 0600’S, ninho 337c), em 20.I.1986, Lestrimelitta sp. havia já construído um tubo de cerume sobre a entrada de P. vicina (Fig. 16) e não havia, externamente, nenhum movimento desta última. Quando abrimos o ninho, verificamos que as Lestrimelitta haviam ocupado todo o vestíbulo e câmaras associadas, mas não havia nenhuma delas no interior da câmara de crias, que se conservava intacta. O vestíbulo e câmaras associadas dos ninhos de $P$. vicina são as estruturas mais complexas que conhecemos dentro de Partamona, e a segunda câmara ou átrio pode, realmente, constituir um ninho falso já que contém todos os elementos de uma câmara de crias, porém todos vazios; além disso, o pequeno orifício na base dessa câmara, que dá acesso à galeria de comunicação com a câmara de crias e alimento, pode ser vedado pelas abelhas (ver adiante).

O vestíbulo pode conter centenas de operárias alojadas nos labirintos formados pela estrutura radicular em seu interior, constituindo a força de defesa do ninho, no qual estas, em caso de ataque, podem retardar ou reter os invasores. Em um caso, quando estudamos um ninho de P. ferreirai (ninho 293c,

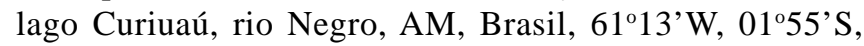
25.VIII.1980), colocamos um pouco de inseticida em "spray" (geralmente usamos apenas éter sulfúrico) para conter a agressividade das abelhas; cerca de 10 minutos depois abrimos o ninho e verificamos que o gargalo de acesso à galeria de comunicação com a câmara de crias e alimento, havia sido totalmente vedado com uma massa de resina esbranquiçada e pegajosa; as abelhas do vestíbulo estavam dormentes, enquanto as da câmara de crias não mostravam sinais de terem sido intoxicadas. É possível que comportamento de defesa semelhante - vedar a entrada da galeria, possa ocorrer em casos de ataque por Lestrimelitta, tanto nesta como em outras espécies de Partamona.

Embora pareça lógico admitir uma seqüência de "passos" evolutivos, desde vestíbulos mais simples até mais “especializados” e complicados, como aqueles construídos por $P$. vicina, não foi possível reconhecer estados discretos passíveis de codificação e análise. Há variação na forma das radículas presentes nas câmaras vestibulares mesmo dentro de uma mesma espécie e, também, nos atributos das câmaras vestibulares assessórias. Partamona mourei, por exemplo, pode apresentar uma ou mais câmaras assessórias conectadas ao vestíbulo, porém, nenhuma delas qualitativamente comparável ao átrio de $P$. vicina que abriga um ninho falso. Além do mais, não há dados precisos para um considerável número de espécies. Desta forma, consideramos apenas três caracteres: número de câmaras vestibulares (caráter 11), comunicação entre o vestíbulo e a câmara de crias (caráter 12) e materiais utilizados na construção das radículas (caráter 13).

\section{Câmara de Crias e Alimento (Caráter 14; Tabela II)}

Em Parapartamona, há uma única câmara contendo os favos de cria e os potes de alimento. Em P. mourei e P. vicina, há uma ou mais câmaras acessórias contendo potes de alimento (usualmente mel mas, às vezes, também pólen) e que se conectam à câmara de crias através de estreitas galerias (Fig. 17). Em $P$. ailyae, também existem câmaras acessórias, porém não obrigatoriamente; encontramos ninhos em que elas não existiam. Em P. pearsoni, pode haver expansões laterais à câmara de crias, mas não com as características das acima descritas; não há galerias, sendo amplamente interligadas (Fig. 31).

Todas as demais espécies, cujos ninhos são conhecidos, constróem apenas uma câmara, contendo as crias e o alimento.

\section{Pilares de Sustentação dos Favos de Cria e Potes (Caráter 15; Tabela II)}

Em Parapartamona, assim como nos demais Meliponini, os favos (ou células de crias nas espécies não construtoras de favos), os potes e o invólucro são sustentados por finos pilares e conectivos de cerume. Em Partamona, todas as estruturas da câmara de crias (favos, invólucro e potes) são sustentadas por pilares de terra e resinas (Figs. 8, 17, 24, 31, 45), permanentes, que transpassam toda a câmara, sendo fixados na parede desta (Kerr et al. 1967; CAMARgo 1970).

\section{ANÁLISE FILOGENÉTICA}

Um dos principais problemas que se coloca a esta análise é a falta de um cladograma consistente para os dados de morfologia. A grande homogeneidade morfológica das espécies resulta, praticamente, na ausência de caracteres informativos, e os poucos que revelam algum significado para inferências filogenéticas (como a forma do $7^{\circ}$ esterno abdominal dos machos 
Tabela III. Matriz de caracteres para as espécies de Partamona. Caracteres 01-15 referem-se aos dados de ninhos e 16-29 aos de cor e forma das abelhas, conforme Pedro \& Camargo (2003). Os caracteres em negrito foram usados para a construção da hipótese de filogenia (Figs. 56, 57). Os estados dos caracteres estão listados na tabela II. * machos não conhecidos; ${ }^{+}$ninho não conhecido.

\begin{tabular}{|c|c|c|c|c|c|c|c|c|c|c|c|c|c|c|c|c|c|c|c|c|c|c|c|c|c|c|c|c|c|}
\hline & 01 & 02 & 03 & 04 & 05 & 06 & 07 & 08 & 09 & 10 & 11 & 12 & 13 & 14 & 15 & 16 & 17 & 18 & 19 & 20 & 21 & 22 & 23 & 24 & 25 & 26 & 27 & 28 & \\
\hline Parapartamona spp. & 0 & & $\mathbf{0}$ & $\mathbf{0}$ & $\mathbf{0}$ & $\mathbf{0}$ & $\mathbf{0}$ & $\mathbf{0}$ & $\mathbf{0}$ & $\mathbf{0}$ & $\mathbf{0}$ & $\mathbf{0}$ & & $\mathbf{0}$ & $\mathbf{0}$ & $\mathbf{0}$ & $\mathbf{0}$ & $\mathbf{0}$ & $\mathbf{0}$ & 0 & $\mathbf{0}$ & 2 & $\mathbf{0}$ & $\mathbf{0}$ & $\mathbf{0}$ & $\mathbf{0}$ & $\mathbf{0}$ & 0 & \\
\hline Part & 0 & - & 1 & 1 & 1 & 0 & 0 & 0 & 1 & 0 & 1 & $?$ & 1 & 0 & 1 & 0 & 0 & 1 & & 1 & 1 & 0 & & 0 & & 2 & 0 & 1 & \\
\hline Part & ? & $?$ & $?$ & $?$ & $?$ & $?$ & $?$ & $?$ & $?$ & $?$ & $?$ & $?$ & $?$ & $?$ & $?$ & 0 & 0 & 1 & 0 & 0 & 0 & 2 & 0 & 0 & 1 & 2 & 0 & 1 & \\
\hline Part & 0 & - & $?$ & $?$ & $?$ & $?$ & $?$ & $?$ & $?$ & $?$ & $?$ & $?$ & $?$ & $?$ & ? & 0 & 0 & 1 & 1 & 1 & 0 & 2 & 0 & 0 & 1 & $?$ & $?$ & $?$ & \\
\hline Par & 0 & - & 1 & 1 & 1 & 0 & 0 & 0 & 1 & 0 & 1 & $?$ & 1 & 0 & 1 & 0 & 0 & 1 & 1 & 1 & 1 & 0 & 0 & 0 & 1 & 1 & 1 & 0 & \\
\hline & 0 & - & 1 & 1 & 1 & 0 & 0 & 0 & 1 & 0 & 1 & 2 & 1 & 0 & 1 & 0 & 0 & $0 / 1$ & 1 & 1 & 1 & 0 & 0 & 0 & 1 & 1 & 1 & ) & \\
\hline & 0 & - & 1 & 1 & 1 & 0 & 0 & 0 & 1 & 0 & 1 & $?$ & 1 & 0 & 1 & 1 & $0 / 1$ & $0 / 1$ & 0 & 1 & 1 & 0 & 0 & 0 & 1 & ? & $?$ & ? & \\
\hline & 0 & - & 1 & 1 & 1 & 0 & 0 & 0 & 1 & 0 & 1 & $?$ & 1 & 0 & 1 & 1 & 0 & $0 / 1$ & 1 & 1 & 1 & 0 & & 0 & & 0 & & 0 & \\
\hline & 0 & - & 1 & 1 & 3 & 0 & 0 & 0 & 1 & 0 & 1 & 2 & 1 & 0 & 1 & 0 & 0 & 1 & 1 & 1 & 1 & 0 & & 0 & & 0 & & 0 & \\
\hline & $?$ & $?$ & $?$ & $?$ & $?$ & $?$ & $?$ & $?$ & $?$ & ? & $?$ & $?$ & $?$ & $?$ & $?$ & $\mathbf{0}$ & 0 & 1 & 1 & 1 & 1 & 0 & & 0 & & $?$ & $?$ & ? & \\
\hline & ? & $?$ & $?$ & $?$ & $?$ & $?$ & $?$ & $?$ & $?$ & ? & $?$ & $?$ & $?$ & $?$ & $?$ & $0 / 1$ & 0 & 1 & 1 & 1 & & 0 & & 0 & & ? & & ? & \\
\hline & ? & $?$ & $?$ & $?$ & $?$ & $?$ & $?$ & $?$ & $?$ & ? & ? & $?$ & & $?$ & $?$ & 1 & 0 & & L & 1 & & & & 0 & & ? & & ? & \\
\hline & 1 & 0 & 1 & 2 & 3 & 0 & 0 & C & 2 & & 1 & & & 0 & 1 & $0 / 1$ & 2 & & 1 & 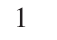 & & & & & & ) & & 1 & \\
\hline & 1 & 2 & 1 & 2 & 0 & 2 & 0 & C & 2 & ( & 2 & & & 1 & 1 & $0 / 1$ & & & & 1 & & & & & & ) & & ) & \\
\hline & 1 & 2 & 1 & 2 & 0 & 2 & 0 & c & 2 & ( & 2 & & & 1 & 1 & & 2 & & 1 & 1 & & & & 0 & & 0 & & 0 & \\
\hline & ? & $?$ & ? & ? & ? & ? & ? & $?$ & ? & . & ? & $?$ & & ? & & ( & 2 & & 1 & & & & & 0 & & 0 & . & 1 & \\
\hline & 1 & 2 & 1 & 3 & 3 & 0 & 0 & c & 1 & ( & 1 & & & c & & & & & 1 & & & & & & & ) & & 1 & \\
\hline & 1 & 2 & 1 & 3 & 3 & 0 & 0 & & 1 & ( & 1 & & & 0 & & & 2 & & 1 & & & & & 0 & & 0 & & 1 & \\
\hline & 1 & 3 & 2 & 4 & 4 & 0 & 1 & 0/1 & 1 & 1 & 1 & & & c & & & & & 1 & & & & & 0 & & 0 & & 1 & \\
\hline Part & 1 & 3 & 2 & 4 & 4 & 0 & 1 & 1 & 1 & 1 & 1 & & & c & & & & & 1 & & 1 & U & & 0 & & 0 & & ) & \\
\hline Part & 1 & $2 / 3$ & 1 & 1 & $2 / 3$ & 0 & 2 & C & 1 & $0 / 1$ & 1 & 2 & 1 & 0 & 1 & ( & 2 & & 1 & 1 & 1 & $0 / 1$ & & 0 & & $\mathbf{0}$ & 0 & 1 & \\
\hline Part & 1 & 2 & 2 & 4 & 4 & 0 & 0 & 2 & 1 & 1 & 1 & 2 & 1 & c & 1 & & 2 & & 1 & 1 & 1 & & & 0 & & 0 & $0 / 1$ & 0 & \\
\hline Part & 1 & 2 & 2 & 4 & 4 & 0 & 1 & 2 & 1 & & 1 & 2 & & & 1 & & & & 1 & 1 & & & & & & 0 & & ) & \\
\hline Part & 1 & 2 & 2 & 4 & & 0 & 1 & & 1 & & 1 & 2 & 1 & & 1 & ( & & & 1 & 1 & 1 & & & & & & & 0 & \\
\hline & 1 & 1 & 1 & 1 & 2 & 1 & 0 & 0 & $1 / 2$ & ( & 1 & 1 & 1 & $0 / 1$ & 1 & ( & 1 & & 1 & 1 & 1 & & & 1 & & 0 & 1 & 1 & \\
\hline Part & ? & $?$ & ? & ? & & ? & $?$ & ? & $?$ & & ? & $?$ & & & ? & 0 & 1 & & 1 & 1 & 1 & & & 1 & & & $?$ & $?$ & \\
\hline & 1 & 1 & 1 & 1 & & 1 & 0 & & 1 & & 1 & 1 & & & 1 & 0 & 1 & & 1 & 1 & 1 & & & & & & 1 & 1 & \\
\hline & 1 & 1 & 1 & 1 & & 1 & 0 & & $1 / 2$ & ( & 1 & 1 & & & 1 & 0 & 1 & & 1 & 1 & 1 & & & & & & & 1 & \\
\hline & 1 & 2 & 1 & 1 & 2 & 1 & 0 & 0 & $1 / 2$ & 0 & 1 & 1 & & & 1 & 0 & 1 & c & 1 & 1 & 1 & & & 0 & & 0 & 1 & 1 & \\
\hline & 1 & 3 & 1 & 1 & 2 & 1 & 0 & & 1 & 0 & 1 & 2 & $?$ & & ? & 0 & 1 & c & 1 & 1 & 1 & 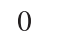 & & 0 & & 0 & 1 & 1 & \\
\hline & 1 & 2 & ? & ? & ? & $?$ & $?$ & ? & $?$ & ? & $?$ & $?$ & ? & $?$ & ? & 0 & 1 & 0 & 1 & 1 & 1 & 0 & 0 & 0 & 1 & 0 & 1 & 1 & \\
\hline & ? & $?$ & $?$ & ? & $?$ & ? & $?$ & ? & $?$ & ? & $?$ & $?$ & ? & $?$ & ? & 0 & 1 & 0 & 2 & 1 & 1 & & & 0 & 1 & ? & $?$ & $?$ & \\
\hline Partamona helleri & $\mathbf{0}$ & - & 1 & 1 & 1 & $\mathbf{0}$ & $\mathbf{0}$ & & 1 & $\mathbf{0}$ & 1 & 2 & & 0 & & 0 & 1 & $\mathbf{0}$ & 1 & & 1 & 0 & 0 & $\mathbf{0}$ & & 0 & 1 & 1 & \\
\hline
\end{tabular}

e a forma dos dentes da mandíbula das operárias), são incongruentes; apenas o basitarso posterior intumescido dos machos parece constituir uma sinapomorfia para as espécies que ocorrem do Equador ocidental até o México (exceto $P$. xanthogastra e $P$. aequatoriana, das quais não se conhecem os machos, e de $P$. musarum, cujo macho estudado é de identidade duvidosa; PEDRo \& CAMARgo 2003).

A ausência de um cladograma melhor resolvido sobre os caracteres morfológicos não permite traçar, com confiança, a história evolutiva dos caracteres comportamentais, especialmente daqueles que podem estar sujeitos a reversões, como no caso do substrato de nidificação.

A diversidade comportamental (em termos de arquitetura dos ninhos, materiais utilizados, etc.), muito mais ampla do que a morfológica, se, por um lado permite o delineamento com maior segurança dos táxons de espécie, por outro, torna difícil o reconhecimento de atributos discretos operacionais em termos de análise filogenética, como discutido anteriormente. Não há caracteres “fortes", não sujeitos a reversões e homoplasias que, por si mesmos, forneçam um insight ou senha que indique um caminho para desvendar um pouco da história de Partamona. Somente em alguns casos, onde a homologia dos caracteres pôde ser inferida, houve a possibilidade de melhorar a definição de alguns grupos de espécies em relação à hipótese prévia de PEDro \& CAMARgo (2003), mas não para informar, de maneira inequívoca, sobre as relações entre estes grupos. Há que se considerar ainda que, para algumas espécies, não temos informações sobre os hábitos de nidificação e para algumas outras, os dados são incompletos.

Diante desses problemas, inicialmente procedemos vários testes sobre as hipóteses de homologia, com os caracteres não ordenados e ordenados seletivamente. Alguns foram reavaliados, desmembrados ou recodificados e outros suprimidos da análise (Tabela III).

Dentre as topologias que resultaram da análise da matriz (Tabela III), em diferentes tratamentos, optamos, para efeito de discussão, pela hipótese apresentada na Fig. 57, que foi escolhida dentre as 24 árvores filtradas de um total de 264 árvores de comprimento mínimo, obtidas através do programa PAUP (busca heurística, otimizada pela opção ACCTRAN). Para obter essas árvores, foram ordenados os caracteres 3, 6, 11, 25 e 26, e excluídos os táxons $P$. vitae, $P$. yungarum, $P$. 
subtilis e $P$. littoralis (das quais não se conhecem os ninhos) e os caracteres 20, 22 e 28. O cladograma escolhido (Fig. 57) foi implementado utilizando-se o programa MacClade, no qual foram reintroduzidos todos os táxons (Fig. 58) com base na informação morfológica (PEDRo \& CAMARGO 2003).

Esse tratamento (Fig. 57), obviamente resulta na hipótese de monofilia para as espécies termitófilas. Todavia, os resultados são os mesmos quando se exclui o caráter 1, e se mantém o caráter 2 não ordenado (com a codificação modificada para 5 estados, para não perder a informação contida no caráter 1: 0 . ninhos não-associados com termiteiros, 1 . ninhos subterrâneos ..., etc., ver Tabela II), sugerindo que a termitofilia surgiu uma única vez, associada com o segundo evento cladogenético da história de Partamona, e que a primeira relação se dá com termiteiros arborícolas. Esse caráter tem forte congruência biogeográfica. Todas as espécies do ramo bilineata / epiphytophila, endêmicas do sudoeste da Amazônia ( $P$. epiphytophila) e do noroeste do Peru até o México (P. peckolti, $P$. aequatoriana, $P$. musarum, P. xanthogastra, $P$. orizabaensis e $P$. bilineata), cujos hábitos são conhecidos, não são termitófilas; apenas $P$. peckolti ocasionalmente nidifica em termiteiros arborícolas (Roubik, in litteris). Todas as demais espécies de Partamona são termitófilas e endêmicas da América do Sul, à leste dos Andes (Figs. 50-53), exceto P. helleri, endêmica do sudeste do Brasil (Fig. 54), que só eventualmente nidifica em termiteiros ativos. Essa congruência na distribuição geográfica do caráter, corrobora a hipótese de que a termitofilia foi a primeira novidade comportamental, e de que surgiu uma única vez na história de Partamona.

Quanto a P. helleri, o hábito de se associar com termiteiros ativos não está disseminado aleatoriamente em toda a população (veja Partamona helleri, p. 340), mas ocorre só localmente na população de Paraopeba, MG (Silveira, com. pessoal), a qual pode, possivelmente, constituir uma espécie distinta. Por esta razão, $P$. helleri foi codificada na matriz como não termitófila. Isso resulta na hipótese de que $P$. helleri constitui um ramo basal (Fig. 57), irmão de todas as espécies termitófilas. Se for codificada como polimórfica quanto a esse caráter, alguns resultados da análise sugerem a hipótese de relações com o grupo cupira. Mas só um conhecimento melhor dos ninhos e do status taxonômico da população de Paraopeba, pode trazer algum esclarecimento.

Por outro lado, há que se considerar que a nidificação nãoassociada com termiteiros possa ser um estado derivado, mesmo porque, no grupo externo, Parapartamona, os ninhos são construídos de forma bastante distinta daqueles das Partamona não termitófilas, embora utilizem substratos equivalentes. Parapartamona não utiliza terra em nenhuma das partes do ninho. Nas espécies conhecidas, $P$. vittigera e $P$. tungurahuana, os ninhos são envolvidos por um espesso batume de resinas consolidadas, aparentemente, com partículas vegetais (Coloma 1986; Camargo, obs. pessoal; Bravo 1993, refere-se ao batume como constituído de cerume, barro, fezes de animais e partículas vegetais, mas nos ninhos que observamos pessoalmente, o constituinte básico era resina). Em Partamona, o uso de terra é comum a todas as espécies, mesmo àquelas não termitófilas. Em um ninho arborícola de $P$. helleri (Ribeirão Preto, SP, Brasil), construído livremente, apenas apoiado sobre uma bifurcação de galhos, todo o batume e partes internas (exceto os favos e potes), eram constituídos de terra compactada com resinas. É possível, portanto, que o comportamento de usar terra, que obviamente estava presente na espécie ancestral de Partamona, tenha surgido em associação com o hábito de nidificar em termiteiros. O uso de um material - no caso terra - já disponível no substrato de nidificação, parece ser um passo evolutivo mais provável, ou mais parcimonioso, do que a aquisição de toda uma série de processos comportamentais para a coleta, transporte e manipulação de um recurso não diretamente associado ao substrato. Nesse caso, considerando a não associação com termiteiros um estado derivado, outras hipóteses sobre configurações evolutivas podem ser obtidas, mas os testes que fizemos não resultaram em cladogramas melhor resolvidos que os anteriores.

A evolução da estrutura de entrada, nos seus diversos atributos (caracteres 3-10), também não fica bem esclarecida. A estriação longitudinal no rebordo (caráter 6), um dos poucos caracteres discretos, tem surgimento independente duas vezes, no ramo $P$. vicina - P. mourei e no ancestral do grupo cupira. Os estados desse caráter (estrias longitudinais no rebordo látero-inferior, e estrias longitudinais radialmente distribuídas em todo o rebordo e rampas), não constituem, pela hipótese apresentada, passos de uma mesma seqüência evolutiva. Não obstante, é possível que a localização filogenética de $P$. vicina - P. mourei não esteja correta. A relação de espécies irmãs entre essas duas espécies está bem justificada por algumas apomorfias (Fig. 57). Todavia, não há caracteres “fortes”, nãoambíguos, que corroborem de maneira inequívoca, a hipótese de relações entre $P$. vicina $-P$. mourei com $P$. testacea. As sinapomorfias para o "grupo" testacea, caracteres 4.2 (funil de entrada encurvado), 9.2 (estrutura de entrada predominantemente de terra) e 16.1 (tegumento da cabeça e tórax amarelo), não são consistentes ou de surgimento único. Em um nível mais inclusivo, no ramo ancestral do clado testacea + nigrior, está o caráter 12.1 (gargalo ausente na entrada da galeria da câmara de crias), que também é homoplástico. Hipóteses alternativas, corroboradas pela estriação no rebordo, levariam o ramo $P$. vicina - P. mourei para uma posição mais próxima do grupo cupira, mas há incongruência com os demais caracteres, na forma como foram codificados nesse estudo.

De um modo geral, apesar das inconsistências na hipótese, ao nível das relações entre alguns grandes ramos, alguns grupos ficaram melhor resolvidos que nas hipóteses apresentadas por PEDRo \& CAMARgo (2003). O ramo que inclui $P$. rustica, $P$. criptica, P. seridoensis, $P$. littoralis, P. mulata, $P$. cupira, $P$. ailyae e P. sooretamae, está justificado pelo estado apomórfico 1 do caráter 6 (estrias longitudinais no rebordo látero-inferior da entrada, Fig. 57) e também pelo 5.2 (rebordo látero-inferior da entrada convexo-revirado), e há poucas dúvidas de que constitua um grupo monofilético (Figs. 57-58); além disso, constitui uma assembléia congruente em termos de contigüidade biogeográfica. O clado $P$. auripennis $-P$. 
combinata (de $P$. nigrior não se conhece o ninho) é justificado pela apomorfia: entrada do ninho em forma de concha lisa ou colher profunda (estado 3, caráter 4; Figs. 56-57). A relação de espécies irmãs entre $P$. vicina e $P$. mourei está bem corroborada principalmente pelos caracteres 6.2 e 11.2 (estrias radialmente distribuídas nas rampas de entrada, e duas ou mais câmaras vestibulares), entretanto, as relações do ancestral destas com $P$. testacea é duvidosa, como discutido acima. As espécies $P$. pearsoni, $P$. gregaria, $P$. batesi, $P$. nhambiquara e $P$. chapadicola (grupo pearsoni), compartilham, principalmente, as apomorfias: funil de entrada vertical (caráter 4.4), ornamentação em forma radicular ao redor do rebordo de entrada (8.2) e rebordos amplos e revestidos com fina película de argila branca ou salmão (10.1). Mas, embora a hipótese de monofilia para esse grupo esteja razoavelmente bem corroborada, permanecem dúvidas quanto à relação entre as espécies. As relações de $P$. ferreirai não podem ser esclarecidas com os dados disponíveis. A hipótese de relações de espécie irmã desta com o grupo pearsoni, se deve apenas à presença de argila branca revestindo parcialmente as rampas da estrutura de entrada; mas, no conjunto, os atributos da estrutura de entrada são muito distintos daqueles das espécies do grupo pearsoni (Tabela III). Por fim, o ramo que inclui P. epiphytophila, $P$. subtilis, $P$. yungarum e $P$. vitae (destas três últimas, os ninhos não são conhecidos), do oeste da Amazônia, e o ramo que inclui as espécies $P$. bilineata, $P$. grandipennis, $P$. xanthogastra, $P$. orizabaensis, $P$. peckolti, $P$. musarum e $P$. aequatoriana, endêmicas de áreas do espaço que vai do noroeste do Peru até as terras baixas do México, são hipotetizados como grupos irmãos (grupo bilineata / epiphytophila). A hipótese de monofilia para esse agrupamento está corroborada apenas pela forma dos dentes da mandíbula (caráter 18.1; dentes grandes com recorte profundo entre eles). Todavia, todas as espécies incluídas (cujos ninhos são conhecidos), constróem ninhos não-associados com termiteiros, em substratos variados, mas comumente sob raízes de epífitas (um atributo codificado como plesiomórfico), e são envolvidos por um espesso labirinto de galerias, cujas paredes são construídas de terra e resinas, de modo que, vistos externamente, são semelhantes a um termiteiro. Esse é um caráter derivado, compartilhado com $P$. helleri, distinto daquele do grupo externo (Parapartamona), que constrói apenas um espesso envoltório simples, de resinas, ao redor do ninho. Também, a forma de construir a entrada, com os rebordos levemente revirados (caráter 5.1) e crenulados, é uma apomorfia para o subgrupo bilineata.

O único ramo monotípico é constituído por $P$. helleri, endêmico da região das matas atlânticas do sudeste do Brasil. Sua condição de ramo basal em relação aos grupos "testacea”, nigrior, pearsoni e cupira, se deve aos hábitos não-termitófilos e ao modo de construir os ninhos. Esta posição filogenética é plausível se, de fato, este caráter (ninhos não-associados com termiteiros) for plesiomórfico, como hipotetizado pelo critério de grupo externo. Todavia, há a possibilidade, como discutido anteriormente, de que seja um caráter derivado homoplástico e, neste caso, P. helleri poderia estar relacionada apenas com o grupo cupira.

\section{Cenário Biogeográfico}

Um problema que se coloca, sob a óptica da biogeografia de vicariância, com relação à hipótese aqui discutida, é a falta de congruência na seqüência de eventos de disjunções, quando comparada com as hipóteses sobre relações entre áreas de endemismo, ou componentes biogeográficos, apresentadas por Cracraft \& Prum (1988), Camargo (1996a), Camargo \& Moure (1996) е АмоRim \& Pires (1996). Embora alguns grupos de espécies (grupos monofiléticos) e algumas espécies estejam segregados em padrões de endemismo "homólogos" àqueles relatados pelos autores acima, a história das relações entre essas áreas, inferida do cladograma biológico (Fig. 58), é discordante em alguns aspectos, especialmente com relação às hipóteses apresentadas por CAMARGO (1996a) e CAMARGO \& Moure (1996) que se baseiam em cladogramas melhor resolvidos, de grupos com igual potencial de fidelidade geográfica e de mesma idade geológica (gêneros Geotrigona e Paratrigona), como já discutido anteriormente em Pedro \& CAMARGo (2003).

Mesmo com alguns agrupamentos melhor corroborados pela adição de caracteres comportamentais, pouco pode ser esclarecido além daquilo que foi discutido por Pedro \& CAmARgo (2003), e somente com relação a alguns ramos principais. Da mesma forma que na hipótese desses autores, a primeira disjunção, que fragmenta a espécie ancestral de Partamona em duas populações, separa o sudoeste da Amazônia (esta área de endemismo é referida como "NapoInambari” por CRACRAFT \& PRUM 1988; SWAm por AMORIM \& Pires 1996 e AmW por CAMARgo 1996a), juntamente com a região noroeste dos Andes e Panamá, América Central e México (Chocó-CA em Cracraft \& Prum 1988; AnMA em Amorim \& Pires 1996, e Pac. em CAMARgo 1996a) - grupo bilineata / epiphytophila (Fig. 49) -, de todo o norte-sudeste tropical da América do Sul (que inclui os componentes biogeográficos norte do Amazonas - NAm, que corresponde ao Cráton das Guianas-Brasil, sudeste - SEAm, que corresponde a toda a área ao sul dos rios Madeira e Amazonas, e Atlântico - Atl, que corresponde à região das matas atlânticas, da Bahia até São Paulo - CAMARGo, 1996a e Amorim \& Pires 1996; Fig. 56a). A segunda disjunção separa o componentes Atl dos componentes SEAm+NAm. No noroeste da região Neotropical (como definida acima, Fig. 56a), segue-se uma disjunção trans/cisandina, separando as terras do oeste do Equador até o México (componente Chocó-CA, subgrupo bilineata), das terras do sudoeste da Amazônia (componente SWAm, subgrupo epiphytophila; Fig. 58). Com relação às áreas de endemismo nos componentes NAm e SEAm, nada pode ser esclarecido, visto que o cladograma biológico, nesse nível, está muito mal resolvido. Além disso, há quatro espécies com distribuição replicada no componente NAm, e duas de ampla distribuição, como será discutido adiante.

Há apenas três cladogramas de área, propostos na literatura (Camargo 1996a; Camargo \& Moure 1996; Amorim \& Pires 
1996), que envolvem toda a região neotropical, mas todos os três são discrepantes entre si em um ou outro nível da seqüência de quebras, ou de relações entre áreas, de modo que, traçados biogeográficos generalizados ainda não podem ser estabelecidos com a consistência desejada (Fig. 56). Com relação ao cladograma de área para Partamona, a maior discrepância se dá no primeiro grande evento de disjunção que, nas hipóteses de Camargo e Amorim \& Pires, ocorre separando todo o NW da região Neotropical (componentes Chocó-CA, SWAm e NAm, Fig. 56) do SE (componentes SEAm e Atl, Fig. 56), aproximadamente ao longo do alinhamento dos rios Amazonas e Madeira. Esta hipótese compete com a aqui apresentada, mas possíveis soluções, em termos de opção, são mais de ordem empírica (corroboração de padrões filogenéticos e endemismo de outros organismos) do que metodológica. São muitos os problemas envolvidos na reconstrução da história de um táxon, como codificação equivocada de caracteres, falta de táxons ou informações incompletas, convergências, etc., de modo que, o padrão hierárquico obtido para os caracteres pode não refletir a história das relações entre diferentes áreas de endemismo. Além disso, os caracteres aqui utilizados não apresentam congruência inequívoca, de modo que várias hipóteses podem ser geradas. De qualquer forma, esta é mais uma hipótese a ser testada, quando outros padrões biogeográficos forem conhecidos para a região neotropical.

Não só a falta de um cladograma biológico melhor resolvido, como também a distribuição de algumas espécies, dificulta a proposição de hipóteses sobre a evolução biogeográfica de Partamona. Este é o caso das distribuições redundantes ou replicadas no componente NAm, como mencionado acima (Figs. 50-52). Quatro espécies são endêmicas desse componente: $P$. mourei (grupo "testacea"), $P$. auripennis (grupo nigrior), $P$. pearsoni e $P$. ferreirai (grupo pearsoni). Apenas $P$. pearsoni se estende até o leste do Pará (Fig. 52). Todavia, são grupos assimétricos com relação ao número de espécies (Fig. 58) e com padrões discordantes no restante da área de distribuição. Partamona testacea e $P$. vicina (do "grupo" que inclui $P$. mourei), são simpátricas e largamente distribuídas na bacia amazônica, incluindo toda a área SWAm (Fig. 50). O grupo que inclui $P$. auripennis (grupo nigrior), com quatro espécies, todas alopátricas entre si, tem larga distribuição, da Venezuela até São Paulo e litoral nordeste do Brasil (Fig. 51). O grupo que inclui $P$. ferreirai e $P$. pearsoni, é mais restrito à Amazônia, com seis espécies, sendo quatro delas mutuamente exclusivas geograficamente. É o único grupo que possui uma espécie endêmica na região de Tefé, AM, e outra na região do baixo Tapajós / Xingu (Fig. 52). A assimetria nos cladogramas (Figs. 57-58) e a incongruência nos padrões de endemismo para as demais espécies, sugerem histórias distintas para cada um dos grupo: diferentes padrões de dispersão, fusão de áreas, respostas distintas aos eventos de vicariância ou, até mesmo, extinções. Mas o que é mais provável, em alguns casos, são os dados taxonômicos ambíguos e incompletos, principalmente no reconhecimento das unidades. É possível, por exemplo, que P. testacea, P. auripennis e P. pearsoni, sejam constituídas, cada uma delas, de mais que uma espécie. Portanto, só um maior detalhamento taxonômico, em níveis mais finos de análise, poderia trazer alguma luz à questão. Mas o fato é que há, pelo menos, três grupos parcialmente replicados, envolvendo os componentes NAm, SEAm e, também, o SWAm (área de distribuição de $P$. testacea e $P$. vicina), mas principalmente o NAm onde, diferentemente dos demais componentes biogeográficos da região Neotropical, há no mínimo, quatro réplicas neste nível de generalidade taxonômica considerado.

Apesar de todos os problemas acima relatados, certos setores do cladograma biológico (Fig. 58) estão melhor resolvidos, tanto em termos filogenéticos como em termos de congruência biogeográfica, e justificam algumas considerações em torno de possíveis eventos causais de cladogênese. Este é o caso dos clados bilineata e epiphytophila, hipotetizados como grupos irmãos e separados pela cordilheira andina equatoriana.

O primeiro clado ou subgrupo, que inclui as espécies $P$. bilineata, $P$. orizabaensis, $P$. grandipennis, $P$. xanthogastra, $P$. aequatoriana, $P$. musarum e $P$. peckolti, ocorre do noroeste do Peru até o México (componente biogeográfico que aqui denominamos de Chocó-CA, como em Cracraft \& Prum 1988; Fig. 56a), e a leste chega até a Venezuela (Figs. 49, 57). O segundo subgrupo, que inclui $P$. epiphytophila, $P$. subtilis e $P$. yungarum (a inclusão de $P$. vitae neste subgrupo, ainda precisa ser melhor corroborada), é endêmico do SWAm, área delimitada, ao norte, aproximadamente ao longo dos rios Uaupés-Negro, ao sul, pelos rios Madeira-Mamoré, e a oeste pela cordilheira dos Andes (Fig. 56a).

O evento cladogenético que deu origem à espécie ancestral do grupo bilineata / epiphytophila, obviamente implica na formação, pretérita, de uma barreira separando as áreas SWAm+Chocó-CA, do norte (NAm, Cráton das Guianas) e sudeste da América do Sul (SEAm+Atl), e estendendo-se aproximadamente ao longo das regiões atualmente ocupadas pelos rios Uaupés-Negro até o Madeira-Mamoré (Figs. 56a, 56c, 58).

Os únicos eventos de grande porte nessa região no período pós-gondwânico, concomitantemente à formação do bloco norte-andino, referem-se à existência de largos sistemas lacustres de água doce, alternados com regimes de água salgada, possivelmente relacionados com as transgressões dos mares de Maracaibo, e cujos limites atingem o alinhamento acima mencionado. A literatura especializada tem sido farta em fornecer relatos sobre evidências da existência desses lagos e mares epicontinentais, porém carece ainda de muito detalhamento em termos de datações e sobre a extensão geográfica dos mesmos. Alguns autores (Hoorn et al. 1995; RÄsänen et al. 1995; HoOghiemstra \& VAn Der Hammen 1998; Ramos \& AlEman 2000; entre outros), todavia, têm atribuído ao Mioceno Médio (ca. 10-15 Ma) a principal transgressão, na qual poderia ter havido conexão entre os mares de Maracaibo e os Paranaenses, constituindo-se em uma barreira, para as faunas continentais, entre o extremo oeste e o leste da páleoAmazônia; mas não há informações sobre a extensão de terras que teriam permanecido emersas na região SWAm.

Pelos padrões biogeográficos aqui relatados, entretanto, 
uma larga extensão deve ter permanecido emersa entre a atual região do Acre, Brasil, e as terras equatorianas pré-andinas (emergentes no Mioceno Médio, ColtoRTI \& OlLIER 2000), onde evoluiu a espécie ancestral do grupo bilineata / epiphytophila.

O endemismo na região SWAm é um fato bem conhecido dos biogeógrafos e exibe considerável congruência entre os padrões determinados para diferentes grupos de organismos (Brown Jr. 1987; Cracraft 1985, 1988; Cracraft \& Prum 1988; Camargo 1996a; Camargo \& Moure 1996; Amorim \& Pires 1996).

O segundo evento de vicariância na história deste grupo, que origina as espécies ancestrais dos subgrupos bilineata e epiphytophila, está, possivelmente, relacionado com a evolução geológica dos Andes equatorianos. Neste contexto biogeográfico, os Andes colombianos, provavelmente, têm pouco ou nenhum significado. No Mioceno Inferior, de acordo com ColtoRTI \& OlLIER (2000), a cordilheira equatoriana não existia e o Pacífico chegava até a parte Oriental; as primeiras terras emergem no Mioceno Médio, mas altitudes da ordem de 3000-4000 m só são atingidas no Plio-Pleistoceno (ca. 2 Ma.).

O padrão atual de disjunção trans- / cisandina é perfeitamente compatível com essa história da evolução da cordilheira (Figs. 49, 56a, 57). Supõe-se que a espécie ancestral do grupo bilineata / epiphytophila distribuía-se, durante o Plioceno, ao longo das terras baixas tropicais da região SWAm, chegando, ao norte, até a região dos atuais rios Napo-Uaupés, e a oeste, até a costa do Pacífico no Equador. A quebra que deu origem à espécie ancestral do subgrupo bilineata, a oeste dos Andes, e à espécie ancestral do subgrupo epiphytophila, a leste (SWAm), teria ocorrido no Plio-Pleistoceno, quando a cordilheira atinge cotas superiores a $3000 \mathrm{~m}$.

Neste cenário histórico hipotetizado, a presença de espécies do subgrupo bilineata do Equador até o México (Fig. 49), só pode ser atribuída à dispersão e sucessivos eventos de vicariância durante o Plio-Pleistoceno.

Sabemos da existência de Meliponini, já no Mioceno Médio, como indica o registro fóssil, nas terras do norte da América Central, sul do México e República Dominicana (bloco denominado “América nuclear”), mas esse fato não constitui evidência suficiente para refutar a hipótese de dispersão PlioPleistocênica, de Partamona, no sentido sul para o norte. Todos os milhares de espécimens encontrados no âmbar da República Dominicana e de Chiapas - México (atribuídos ao Mioceno Inferior, ca. 15-20 Ma), pertencem a táxons relacionados com Plebeia (s.str.), um gênero que atualmente ocupa toda a região Neotropical. Nunca foram encontrados espécimens relacionados com Partamona ou com outros gêneros atuais de Meliponini (CAmARgo et al. 2000). Esse fato apenas sugere que a história das relações entre a América Central e a América do Sul é muito mais complexa e implica eventos muito mais antigos, mas provavelmente não relacionados com as terras do Chocó, envolvendo espécies na linha de ancestralidade de poucos ou de apenas um dos grupos (Plebeia) como atualmente conhecemos.

Há, ainda, uma hipótese alternativa ou concorrente de caráter ecológico - ciclos climáticos Quaternários--, para explicar as disjunções trans- / cisandinas, comentada detalhadamente por CRACRAFT \& PRUM (1988), que postula trocas faunísticas ou dispersões durante os períodos interglaciais úmidos e quentes, pelo norte dos Andes colombianos e Venezuela. Mas o caso aqui apresentado, trata de grupos irmãos, um deles endêmico do oeste do Equador até o México e, o outro, endêmico do sudoeste da Amazônia (SWAm), sem nenhuma relação com o leste dos Andes colombianos e Venezuela; portanto, é mais provável que uma única espécie (ancestral do grupo bilineata / epiphytophila), e uma única vez, esteve distribuída continuamente do sudoeste da páleo-Amazônia até a costa pacífica do Equador, antes do soerguimento dos Andes equatorianos, como discutido anteriormente.

Sobreposições e trocas faunísticas são observadas ao norte da cordilheira dos Andes e de Mérida, mas sem nenhuma relação com a fauna do componente SWAm. Essa sobreposição, que pode ser atribuída ao Quaternário recente, se dá com grupos de Meliponini relacionados com o cráton das Guianas-Brasil (componente NAm) e, em alguns casos, se estende até o Panamá.

Para finalizar, se considerarmos, neste contexto, a hipótese de relações de grupos irmãos entre Partamona e Parapartamona (Pedro \& CAMARgo 2003), então a história geológica e biogeográfica do noroeste da América do Sul seria bem mais complexa. Atualmente, Parapartamona é endêmica das encostas andinas, de ambos os lados, na Colômbia e Equador, entre 1500 e $2700 \mathrm{~m}$ de altitude (CoLOMA 1986; Bravo 1992; GonZÁLEZ-B \& NATES-PARRA 1999; Camargo, obs. pessoal), enquanto Partamona chega a cerca de $2000 \mathrm{~m}$. Se hipotetizarmos que Parapartamona surgiu por vicariância, quando o bloco norte-andino (terras alóctones acrescidas na borda noroeste do continente, fide Ramos \& Aleman 2000) ainda era mais baixo, e não por exclusão ecológica, então teremos que considerar a possibilidade de dois eventos de vicariância e, talvez, um de dispersão.

\section{NINHOS - DESCRIÇÕES}

Os ninhos são descritos na seqüência dos agrupamentos indicados na Fig. 58. Na Tabela I estão relacionadas as espécies para as quais não temos dados de ninhos ( $P$. littoralis, $P$. sooretamae, $P$. yungarum, $P$. vitae, $P$. subtilis, $P$. nigrior e $P$. grandipennis).

A distribuição geográfica das espécies está representada nas Figs. 49-54, baseadas em Pedro \& CAmargo (2003). Novos registros foram acrescentados para $P$. batesi, $P$. grandipennis e P. peckolti.

$\mathrm{Na}$ relação de ninhos examinados, os números correspondem ao material depositado em nossa coleção (material seco e fixado, e partes dos ninhos, além de slides e anotações originais).

Partamona bilineata (Say, 1837) (Fig. 49)

Hábitat e substrato. Terras baixas do México até a Guatemala 
(Fig. 49). Os únicos registros que temos de literatura são os trabalhos de WHEELER (1913), RAu (1943) e GonZÁLEs (19831984), que indicam ninhos semi-expostos sob pontes, galerias sob estradas e buracos e fendas em paredes e ruínas (Tabela I). Todo o ninho, ou parte, envolvido por labirintos e canais, cujas paredes são construídas com terra e resinas. Como relatado no item "Substrato de Nidificação" (p. 315), todas as espécies conhecidas, endêmicas de áreas dentro do espaço geográfico que vai do noroeste do Peru até as terras baixas do México, não são termitófilas.

Estrutura de entrada. De terra e resinas. Pela foto apresentada por RAU (1943), muito semelhante àquelas de $P$. musarum e $P$. orizabaensis. Em forma de funil, com a boca ovalada com cerca de 4,0 cm de altura. A contra-rampa bem polida com resinas, de maneira que fica um pouco brilhante. A margem da borda superior com alguns pequenos alvéolos e, ao redor de toda a entrada, as construções tubulares de terra e resinas comuns à maioria das espécies de Partamona.

Vestíbulo. Anexo à entrada, com as estruturas radiculares anastomosadas, de terra e resinas, e em comunicação com os canais que envolvem o ninho. Pela foto apresentada por RAU (1943), não é possível saber se havia potes ou outras estruturas. Também não há informações sobre a comunicação entre o vestíbulo e a câmara de crias.

Câmara de crias e alimento. Não há informações.

\section{Partamona xanthogastra Pedro \& Camargo, 1997}

(Fig. 49)

Hábitat e substrato. É endêmica das matas do oeste do Panamá (Fig. 49). A única informação existente na literatura (RoubiK 1992) indica que esta espécie nidifica sob raízes de epífitas.

\section{Partamona orizabaensis (Strand, 1919)} (Fig. 49)

Hábitat e substrato. Ocorre nas matas das terras baixas desde Vera Cruz, México, até a Costa Rica (Fig. 49). Nidifica, de acordo com Wille \& Michener (1973) e WiLle \& OROZCo (1975), em cavidades no solo, entre as bases de folhas de palmeiras, em ninhos abandonados de aves, ou até quase totalmente expostos, às vezes em grandes agregações (Roubik, in litteris, relata que viu agregações nas paredes da casa antiga de Cortez, Vera Cruz, VC, México; os ninhos separados uns dos outros por cerca de 20-30 cm; Tabela I). WilLE \& Michener (1973) apresentam descrições e uma série de fotos dos ninhos de $P$. orizabaensis (= T. cupira). Os ninhos são envolvidos por camadas sucessivas de galerias e labirintos, com as paredes construídas com terra e resinas. São dos autores supra citados os dados que seguem abaixo.

Estrutura de entrada. Em todos os aspectos, semelhante à de P. musarum; em forma de funil alongado, cinza, de terra e resinas. A boca, aproximadamente triangular, com 2,5 a 11,0 cm de altura; o orifício de comunicação com o vestíbulo com 0,9$1,5 \mathrm{~cm}$ de diâmetro. Não há ornamentos ou estrias, apenas o rebordo crenulado. Na parte inferior, com túbulos de terra e resinas.

Vestíbulo. Preenchido com estruturas radiculares de terra e resinas. Não há registros de potes ou outras estruturas no vestíbulo e nem informações sobre a galeria de comunicação com a câmara de crias.

Câmara de crias e alimento. Semelhante à de P. helleri. Favos envolvidos por finas lamelas cerosas. Casulos com 0,6 x 0,35 $\mathrm{cm}$. Os potes de alimento, abaixo dos favos de crias, com 1,3$1,5 \times 1,2-1,3 \mathrm{~cm}$, marrons e formando uma massa compacta. Todo o conjunto sustentado por finos pilares permanentes de terra e resinas. WiLle \& Orozco (1975) descrevem o processo de enxameação desta espécie em uma cavidade em um termiteiro abandonado que, anteriormente, abrigava um ninho de Scaura latitarsis (item Comentários Gerais, p. 312). Outros detalhes em Wille \& Michener (1973).

\section{Partamona peckolti (Friese, 1901)}

(Fig. 49)

Hábitat e substrato. Ocorre na costa do Pacífico, desde as matas do noroeste do Peru, Equador, vales andinos na Colômbia, chegando até o Panamá e, a leste, até a Venezuela (Fig. 49). Utiliza os mesmos tipos de substratos que $P$. bilineata, P. orizabaensis, P. epiphytophila e P. helleri: sob massa de raízes de epífitas, buracos e fendas de rochas, principalmente em construções humanas e ruínas, às vezes em grandes agregações (Michener 1946; Villa \& Vergara 1982; NatesParRa \& CePeda 1983; Coloma 1986; ParRa 1990; RoubiK 1983, 1992; Camargo, obs. pessoal; Tabela I). Roubik (in litteris) observou no Panamá, agregações com mais de 50 ninhos. Ocasionalmente também pode ser encontrada em termiteiros, como relatado por NATES-PARRA \& CEPEDA (1983), na Colômbia, e por Roubik (in litteris) na ilha de Barro Colorado, Panamá. Todo o ninho, como em $P$. orizabaensis, $P$. bilineata, $P$. musarum, $P$. aequatoriana, $P$. epiphytophila e $P$. helleri, envolvido por um espesso batume de terra e resinas, entremeado por galerias e labirintos.

Estrutura de entrada. Coloma (1986) refere-se à entrada do ninho como de aspecto campaniforme e construída com terra, resinas e partículas vegetais (provavelmente material do substrato incorporado à resina); com 5,5 cm de altura por 4,2 cm de largura; o orifício com 1,1 x 0,8 cm; a rampa inferior horizontal, com 3,0 cm de comprimento e a contra-rampa 5,5cm. Na parte inferior, com muitos túbulos de terra e resinas.

Vestíbulo. CoLoma (1986) descreve apenas um emaranhado de conectivos, não se refere a potes, lamelas cerosas e galeria de comunicação com a câmara de crias. Roubik (in litteris), entretanto, que examinou mais de 80 ninhos de P. peckolti no Panamá, menciona que a comunicação entre o vestíbulo e a câmara de crias é feita através de uma galeria, que se inicia em uma projeção tubular, com ca. de 2,0 cm de comprimento por 1,0 cm de diâmetro, na parede posterior do vestíbulo, construída com resinas e muito endurecida, semelhante àquela descrita para P. epiphytophila.

Câmara de crias e alimento. O ninho todo, descrito por 
Coloma (1986), media, externamente, $51,0 \mathrm{~cm}$ de altura por 40,0 cm de diâmetro. Envolvido por um emaranhado de canais, com as paredes de terra e resinas e transpassado por raízes. A câmara de crias media, aproximadamente, 13,0 cm de diâmetro; casulos com 0,60 x 0,38 cm. O invólucro ausente, ou apenas uma fina lamela. Os potes, na parte inferior da câmara, com 1,2-1,9 x 1,2$1,6 \mathrm{~cm}$. Coloma anota que o conjunto estava sustentado por pilares e conectivos cerosos; não faz referência aos pilares de terra e resinas.

Ninhos examinados. 404c - Sta. Rosa, Equador, Andes ocidentais, 2450 m (estrada velha para Esmeraldas, $100 \mathrm{Km} \mathrm{NW}$ de Quito), 7843’W, 0³'S, 31.V.1987 (Camargo, Onore).

Distribuição geográfica. Novos registros: "Ecuador, El Oro, 2.II.01 S341,424' W 79³5,075', 944 m, Rasmussen, Ex: Adenaria floribunda (Lythraceae)”, (01 op., NHM-Lima); "Peru, Lambayeque, 28.XII.82, O. Lordova” (02 ops., MHN-Lima); "Peru, Trujillo, 28.VI.82, A. Carbajal” (02 ops., MHN-Lima). Se estas duas últimas etiquetas de procedência estiverem corretas, indicam que $P$. peckolti chega até bem ao sul do grande deserto de Sechura, na costa do Pacífico, noroeste do Peru. É o primeiro registro de Meliponini para essa região.

\section{Partamona aequatoriana Camargo, 1980} (Fig. 49)

Hábitat e substrato. Ocorre nas matas das terras baixas da costa do Pacífico, do noroeste do Equador até o Panamá (Fig. 49). Sobre P. aequatoriana, o único relato disponível é o de Coloma (1986). De acordo com sua descrição e ilustração, o ninho estudado em La Florida, Pichincha, Equador, se encontrava sob raízes de epífitas.

Estrutura de entrada. Pelas informações do autor acima, não difere daquelas de $P$. musarum e $P$. orizabaensis $(=T$. cupira) descritas por Wille \& Michener (1973) e de $P$. epiphytophila. É constituída de terra e resinas, com cerca de $12 \mathrm{~cm}$ de altura por 6,0 $\mathrm{cm}$ de largura e 3,0-3,5 cm de profundidade; em forma de concha acústica com a rampa inferior aproximadamente horizontal-plana, e a contra-rampa em abóbada. A margem externa apenas irregular crenulada; não há estrias ou outros ornamentos. Na parte inferior da entrada, muitas projeções tubulares "a manera de barbas", segundo Coloma (1986). O orifício, no fundo do funil de entrada, com 1,1 x 0,9 cm de diâmetro.

Vestíbulo. Apenas um emaranhado de conectivos de resinas e "cera" (?), com diâmetros de 0,3 a 0,8 cm, em comunicação direta com a câmara de crias. CoLoma (1986) não faz qualquer referência sobre a existência de galeria comunicando o vestíbulo com a câmara de cria, potes vazios ou outras estruturas.

Câmara de crias e alimento. Semelhante àquela descrita para P. epiphytophila, com 19,0 cm de altura por 14,0 cm de diâmetro, envolvida por um batume negro de $0,10-0,15 \mathrm{~cm}$ de espessura, frágil e quebradiço, seguido por um labirinto de canais e galerias, com muitas raízes entremeadas. Os favos horizontais, envolvidos por 5-6 lamelas de invólucro. Casulos com 0,53 x $0,33 \mathrm{~cm}$. Os potes de mel e pólen, na parte inferior e lateral do ninho, entre as lamelas de invólucro, de forma ovóide, com 1,4 cm de altura por $1,1 \mathrm{~cm}$ de diâmetro. Todo o conjunto sustentado por pilares comuns de terra e resinas e conectivos cerosos (Coloma 1986).

\section{Partamona musarum (Cockerell, 1917)} (Fig. 49)

Hábitat e substrato. Ocorre da Nicarágua até o noroeste da Colômbia (Fig. 49). Os dados que seguem, são baseados nas fotos e descrições sucintas apresentadas por Wille \& Michener (1973). Nidifica, conforme esses autores, na trama de ramos vegetais de ninhos abandonados de aves em galhos de árvores (Tabela I); também, sob epífitas, raízes de Anthurium e Bromeliaceae (Roubik, in litteris).

Estrutura de entrada. De terra e resinas; vista de frente, em triângulo rebaixado, com rebordo apenas crenulado e sem estrias ou outros ornamentos. A rampa inferior aproximadamente horizontal, plana; a superior em forma de abóbada; o orifício, no fundo do funil, com 0,9-1,5 cm. Sob a entrada, muitos túbulos de terra e resinas.

Vestíbulo. Não forma uma câmara com limites distintos, apenas um labirinto de conectivos e pilares anastomosados, de terra e resinas; não há referências a potes e outras estruturas, nem sobre a maneira de comunicação entre o vestíbulo e a câmara de crias.

Câmara de crias e alimento. Muito semelhante ao ninho de $P$. helleri. Todo o ninho envolvido por um emaranhado de canais, com paredes de terra e resinas, em três a quatro camadas sucessivas. Na parte interna, 3 a 4 camadas de invólucro ceroso, marrom-escuro, envolvem os favos de cria. Casulos com 0,6 x $0,35 \mathrm{~cm}$. Os potes de mel e pólen, na parte inferior da câmara, com 1,3-1,5 cm de altura por 1,2-1,3 cm de diâmetro. Todo o conjunto sustentado por finos pilares permanentes de terra e resinas. O cerume das edificações, de cor marrom-escuro. Outros detalhes, em WiLLE \& Michener (1973).

\section{Partamona epiphytophila Pedro \& Camargo, 2003} (Figs. 1b, 3, 4, 49)

Hábitat e substrato. Habita as matas densas e úmidas do oeste da Amazônia, chegando até as encostas andinas (Fig. 49). Como o nome sugere, nidifica principalmente sob a trama de raízes de epífitas (Figs. 3, 4; Tabela I). Em espaços antrópicos, como observado em Rio Branco, AC (M. L. Oliveira, com. pessoal), P. epiphytophila pode utilizar qualquer substrato com alguma proteção, como beirais e espaços entre o forro e telhados de casas, fixados sob caixas d'água, buracos em muros, etc. Apenas um, dentre os ninhos estudados, se encontrava associado a um pequeno termiteiro localizado em um oco semiaberto de um tronco de árvore (ver "Ninhos examinados", 740c). Isso indica, da mesma forma que em $P$. helleri, que toda a terra utilizada nas edificações (todo o batume e partes internas do ninho) é transportada de outros locais, diferentemente do que ocorre quando nidifica sob raízes de epífitas, quando utiliza, também, o material vegetal decomposto. É a única espécie conhecida, além de $P$. helleri, na América do Sul a leste dos Andes, que não é termitófila (é possível que $P$. subtilis e $P$. 
yungarum também não sejam termitófilas).

Estrutura de entrada. Em forma de uma profunda concha acústica, constituída de terra e, principalmente, resinas, de modo que a superfície das rampas é enegrecida e, às vezes, brilhante (Fig. 1b). É uma das entradas mais simples dentre as Partamona; não há rebordo revirado ou qualquer tipo de ornamentação. As margens externas são apenas crenuladas ou com vilosidades e orifícios acompanhando as irregularidades do substrato (Figs. 1b, 4). Em algumas entradas vistas em Rio Branco, AC (M. L. Oliveira, com. pessoal) a rampa superior é lamelada e há mais terra do que resinas na composição da estrutura. O tamanho é muito variável, entre 5,0-15,0 cm de altura por 4,0-9,0 cm de largura. A rampa inferior é, geralmente, horizontal e a contra-rampa côncava, em forma de abóbada, com reentrâncias e ondulações na superfície, porém muito lisa e bem polida com aplicações de resinas enegrecidas. A rampa superior chega a medir 10,0-15,0 cm de extensão. No fundo das rampas, que terminam em uma superfície mais ou menos ondulada, há um, dois ou mais grandes orifícios (2,0-3,0 cm de diâmetro), irregulares, de comunicação com o vestíbulo.

Abaixo da entrada há, freqüentemente, uma grande massa de túbulos, construídos com terra e resinas, e que se comunicam com o vestíbulo (Fig. 4).

Vestíbulo. Uma câmara, não diferente daquelas das espécies termitófilas; com 15,0-20,0 cm de altura, por 10,0-15,0 cm de diâmetro e preenchida por fortes estruturas radiculares de terra e resinas (0,5-1,0 cm de diâmetro) e amplamente interligada aos canais tubulares que circundam o ninho (Fig. 4). Alguns potes (1,5 x 1,2 cm), de cor marrom, vazios ou contendo mel ou pólen, são encontrados fixados nas radículas. Não há lamelas cerosas. Em vários ninhos, apenas uma parede de 0,3-0,4 cm de espessura, de resinas e material do substrato, separa o vestíbulo da câmara de crias. A conexão entre estas duas câmaras se dá através de uma curta galeria, que se inicia na parede posterior do vestíbulo, em uma larga projeção cônica, com cerca de 3,0 cm de comprimento por 2,5 cm de diâmetro na base, e por 1,21,3 cm no ápice, onde há um fino rebordo em forma de gargalo de garrafa, circundando o orifício de entrada (este com ca. 0,7 cm de diâmetro). Logo após o orifício de entrada, a galeria se expande para 1,2-1,5 cm de diâmetro e se prolonga na forma de um tubo até a região dos potes de alimento, nos lados ou na parte inferior da região de crias. As paredes do vestíbulo e galerias são fortemente revestidas com resinas e bem polidas.

Câmara de crias e alimento. Também a câmara de crias não difere daquelas das espécies termitófilas. Uma única câmara, aproximadamente esférica com 20,0-25,0 cm de diâmetro, abriga, na parte superior, os favos de cria e na parte inferior os potes de alimento. Casulos com ca. 0,6 x 0,4 cm, espaço entre os favos, $0,4 \mathrm{~cm}$. Os potes de mel e pólen com 1,8-2,0 cm de altura por 1,3-1,5 cm de diâmetro; os de pólen, mais próximos da região de crias. Geralmente o ninho é envolvido por uma ou duas camadas de batume $(0,1 \mathrm{~cm}$, ou mais de espessura), de terra e resinas, ressecado e quebradiço, e entremeado de galerias e labirintos que se comunicam com o vestíbulo. Internamente, 23 lamelas cerosas, moles, envolvem somente os favos. As paredes da câmara com 0,3-0,4 cm ou mais de espessura, são constituídas de terra, partículas do substrato e resinas. Todas as estruturas internas do ninho são sustentadas por finos pilares de terra e resinas. Quando nidifica sob epífitas, algumas raízes desta são envolvidas com resinas e incorporadas à trama de sustentação do ninho. As células, potes e invólucro interno, de cor castanho-amarelada.

Ninhos examinados. 85c, 86c - São Paulo de Olivença, AM, Brasil, margem direita do rio Solimões, 20.I.1977 (Camargo, Mazucato); 97c Vila Nova do Tonantins, AM, Brasil, SA-19, 68-3f ix, 22.I.1977 (Camargo, Mazucato); 103c - Fonte Boa, AM, Brasil, SA-19, 66-3f xii, 25.I.1977 (Camargo, Mazucato); 213c - Foz do rio Curicuriari, rio Negro, AM, Brasil, 66²9'W, 0¹3’30”'S, 15-21.VII.1980 (Camargo, Mazucato); 416c - Archidona, Cuevas de San Bernardo, Equador, Andes Orientais, 750 m., 77²9'W, 055'S, 6.VI.1987 (Camargo, Onore, Bravo); 520c Carauarí, rio Juruá, vila Simpatia, AM, Brasil, 6654’W, 453’S, 22.VII.1993 (Camargo, Pedro, Mazucato); 558c, 573c - Forte da Graça, rio Juruá, AM, Brasil, 666’ W, 3³9’S, 3-6.VIII.1993 (Camargo, Pedro, Mazucato); 574c, 597c - Lago Uará, rio Solimões, AM, Brasil, 65³5’W, 241’S, 9-13.VIII.1993 (Camargo, Pedro, Mazucato); 614c - Paraíso, rio Japurá, AM, Brasil, 655'W, 29'S, 20.VIII.1993 (Camargo, Pedro, Mazucato); 728c - Camanaus, rio Negro, AM, Brasil, 6653'17'W, 08'51”', 30.VI.1999 (Camargo, Pedro, Mazucato); 735c - TapurucuaraMirim (foz do rio Marié), rio Negro, AM, Brasil, 6653'17”W, 0²5’17.6”, 01.VII.1999 (Camargo, Pedro, Mazucato); 740c Tapurucuara-Mirim, rio Negro, AM, Brasil, 66²4’22”W, 0²5’18”S, 02.VIII.1999 (Camargo, Pedro, Mazucato).

\section{Partamona testacea (Klug, 1807)}

(Figs. 1d, 3, 5-8, 50)

Hábitat e substrato. É a única espécie do gênero que constrói ninhos subterrâneos obrigatórios (KerR et al., 1967; CAMARGO, 1970, 1980), em termiteiros [em um caso identificado como Syntermes spinosus (Latreille, 1804), ninho 55c], em ninhos de Atta spp. e em vários outros tipos de cavidades subterrâneas, não-associadas com insetos sociais, em profundidades variáveis, entre 40,0 e 100,0 cm (Figs. 3, 5-8; Tabela I). Ninhos de $P$. testacea foram descritos e ilustrados, em detalhes, pelos autores acima citados. É uma das espécies mais conspícuas de toda a Amazônia, principalmente na região oeste, onde chega até as encostas andinas orientais, a ca. $1000 \mathrm{~m}$ de altitude (Fig. 50); constrói ninhos tanto em lugares ensolarados como em lugares sombreados e úmidos nas matas. É freqüente encontrála em grandes agregações, especialmente em ninhos ativos de Atta spp., como aqueles de Vendaval (região de São Paulo de Olivença, AM, Brasil, ninhos 71- 81c), onde havia 12 ninhos (Fig. 3), e em Archidona, Equador (750 m de altitude) com 16 ninhos. Roubik (in litteris) também observou agregações em ninho de Atta sp. na região de Yasuni, Napo, Equador. Em termiteiros, grandes agregações são menos comuns (Fig. 5).

Estrutura de entrada. A entrada tem a forma de uma concha acústica projetada verticalmente sobre o substrato, ou a forma de um funil encurvado (Figs. 1d, 5-8). É construída com terra praticamente pura, consolidada provavelmente com líquidos de origem intestinal das abelhas (CAMARgo 1980); recebe aplicações de resinas apenas na parede do funil que desce em direção ao orifício de comunicação com o vestíbulo. É bem polida somente nas rampas. Em geral, a estrutura é muito frágil, quase sempre bastante úmida e se desfaz facilmente sob chuva 
forte. Apresenta 6,0-7,0 cm de altura por 4,0-5,0 cm de largura; as bordas são reviradas, mas não há estrias ou qualquer outra ornamentação (Figs. 1d, 5-8). É a estrutura de entrada mais simples dentre as Partamona. Não forma um fundo côncavo como nas demais espécies; as paredes formam um funil que se estreita até formar o orifício (1,2-1,5 cm de diâmetro) de comunicação com o vestíbulo (Figs. 1d, 8). Não há estruturas tubulares ao redor da entrada, como é comum na maior parte das espécies de Partamona.

Vestíbulo. Contíguo à entrada; constitui-se de uma câmara ovalada com cerca de 10,0-15,0 cm de altura por 6,0-9,0 cm de diâmetro, com as paredes revestidas com resinas, às vezes com espessura de até $0,1 \mathrm{~cm}$. As estruturas radiculares com 0,2-0,8 $\mathrm{cm}$ de diâmetro, de terra e resinas, finamente trabalhadas e fortemente anastomosadas, formam um emaranhado preenchendo toda a câmara (Fig. 8); apenas ligada às paredes através de delgados conectivos, de modo que toda a estrutura pode ser retirada intacta. Usualmente, há, fixados nas radículas do vestíbulo, pequenos potes vazios (ca. de 1,5 x 1,0 cm) de cerume ressecado. Não há lamelas cerosas; em apenas um ninho (67c), observamos uma pequena lâmina, semelhante às do invólucro, fixada junto aos pequenos potes vazios.

Na parte inferior do vestíbulo, um orifício com 1,0-1,2 cm de diâmetro dá acesso a uma longa galeria (ca. 20,0-80,0 cm de extensão por 1,5-1,8 cm de diâmetro) de comunicação com a câmara de crias, terminando na parte superior ou lateral desta (Fig. 8). As paredes desta galeria são impermeáveis, com fino revestimento de resinas.

Câmara de crias e alimento. Constitui-se de uma só câmara, como na maioria das Partamona, e é parcial ou inteiramente escavada no substrato; as paredes são bem polidas e toda a metade superior é impermeabilizada com fino revestimento de resinas (0,1-0,2 cm de espessura). Na parte inferior há um longo canal de drenagem (15,0-30,0 cm de comprimento, ou mais, por 1,5-2,0 cm de diâmetro), que desce verticalmente (Fig. 8).

Os favos, dispostos horizontalmente na parte central superior da cavidade e envolvidos por 4-5 finas lamelas de invólucro; as camadas mais externas, afastadas 1,0-2,0 cm das paredes da câmara, de cerume e resinas, ressecadas e quebradiças e formando galerias que protegem o ninho contra a água. Os casulos com ca. 0,55 x 0,40 cm; o espaço entre os favos com ca. $0,40 \mathrm{~cm}$.

Os potes de mel e pólen geralmente formando uma massa compacta, sob o invólucro, na parte inferior da câmara; em alguns casos estão também envolvidos pelo invólucro (Fig. 8). Não há distinção entre os potes de mel e pólen, ambos com ca. 1,5-2,0 cm de altura por 1,2-1,5 cm de diâmetro; de cor castanhoavermelhada, como o invólucro interno e células. Todo o conjunto de estruturas do ninho é sustentado por finos pilares de terra e resinas (Fig. 8).

Ninhos examinados. S/N - Manaus, AM, Brasil, I-II.1963 (Kerr, Sakagami, Zucchi, Portugal-Araújo, Camargo); S/N - Porto Velho, RO, Brasil, 12-22.X.1966 (Camargo); 55c, 58c - Benjamin Constant, AM, Brasil, 14.I.1977 (Camargo, Mazucato); 63c, 64c, 67c, 71c-81c Vendaval, AM, Brasil, SA-19, 69-3h vi, Aldeia Ticuna, 16-17.I.1977 (Camargo, Mazucato); 121c - São Luís do Tapajós, PA, Brasil, 56²14’W,
4²6'S, 14-17.I.1979 (Camargo et al.); 137c - Santana, PA, Brasil, 553' W, 2059'S, 21-23.I.1979 (Camargo et al.); 341c, 342c - Rio Ipixuna, AM, Brasil, 6320’W, 60’S, 22.I.1986 (Camargo, Mazucato); 411c - 414c - Arquidona, Cuevas de San Bernardo, Equador, Andes Orientais, 750 m., 7749’W, 055’'S, 6.VI.1987 (Camargo, Onore, Bravo); 544c, 550c, 551c - Bacururu, rio Juruá, AM, Brasil, 66º $11^{\prime} \mathrm{W}, 3^{\circ} 45^{\prime}$ 's, 30.VII-1.VIII.1993 (Camargo, Pedro, Mazucato); 571c - Forte da Graça, rio Juruá, AM, Brasil, 666’ W, 3³9’S, 6.VIII.1993 (Camargo, Pedro, Mazucato).

\section{Partamona mourei Camargo, 1980}

(Figs. 1f, 9-12, 50)

Hábitat e substrato. Endêmica das matas ao norte dos rios Negro e Amazonas (Brasil / Guianas; Fig. 50). Nidifica em termiteiros arborícolas externos, do tipo estróbilo, construídos de terra (em um caso identificado como Amitermes excellens Silvestri, 1923, ninho 271c, Tabela I). Esses termiteiros são muito comuns, fixados nos troncos de grandes árvores e em paredes de habitações humanas na região do médio e baixo rio Negro, AM, e região do Trombetas, PA(Figs. 10, 11). Geralmente, esses termiteiros são de terra de cor acinzentada e não pretos como aqueles da região do baixo Tapajós e que foram identificados como sendo da mesma espécie. Não constrói grandes agregações, às vezes quatro ou cinco ninhos em um mesmo termiteiro, mas com as entradas distantes umas das outras; o mais comum é encontrar ninhos solitários; às vezes constrói ninhos em consórcio com outras espécies de Partamona (veja Partamona ferreirai, p. 334).

Estrutura de entrada. A entrada é bastante semelhante na forma, textura e material utilizado à de $P$. vicina, da qual, supostamente é a espécie irmã. É construída com terra pura, geralmente em baixo relevo, acinzentada, da mesma cor que o substrato (de onde parte ou todo o material utilizado é obtido); com acabamento rústico (porém mais liso que aquele de $P$. vicina), granulado, com os grãos de quartzo bem visíveis; nas bordas, as bolotas de terra (correspondentes às cargas transportadas) são dispostas irregularmente. A ornamentação consiste de fortes estrias radialmente dispostas em todo o rebordo, lembrando as entradas de P. vicina (Figs. 1e, 1f). Nos ninhos da região do rio Trombetas, os espaços entre as estrias na rampa superior são sulcados transversalmente, dando um aspecto peculiar à entrada (Fig. 9); nas entradas dos ninhos da região do rio Negro, só eventualmente aparecem esses sulcos e as entradas são bem menores (Fig. 12). A maior estrutura de entrada que estudamos (ninho 188c, rio Trombetas), media 22,0 cm de altura (Fig. 9). Diferentemente de $P$. vicina, a rampa inferior é quase vertical e separada do rebordo estriado por uma quina em ângulo agudo (Fig. 1f). O orifício de comunicação com o vestíbulo, no fundo do funil de entrada, com ca. 2,0 x 0,8-1,0 cm. Não há estruturas tubulares na parte inferior da entrada.

Vestíbulo. Constituído de uma única câmara irregular escavada no substrato (às vezes bastante grande, $50,0 \mathrm{~cm}$ ou mais de altura por 20,0-25,0 cm de largura - ninho 188c), ou de uma câmara central, conectada com o orifício de entrada, e várias pequenas câmaras satélites conectadas a esta por meio de galerias. As paredes são de terra (do termiteiro) compactada 
com resinas. A câmara principal é, usualmente, preenchida por grossas radículas de terra e resinas, às vezes formando extensas lamelas anastomosadas, com 4,0-6,0 cm de largura por 1,0-1,5 cm de espessura, constituindo labirintos entre elas, como em $P$. vicina (Fig. 17). Em alguns casos são firmemente conectadas às paredes do vestíbulo e, em outros, apenas levemente, de modo que todo o conjunto pode ser retirado. Junto às radículas, ou nas câmaras acessórias, sempre há pequenos potes (ca. 1,0 $-0,8 \mathrm{~cm}$ ) de cerume ressecado, contendo substância aquosa ácida. Em um ninho foram encontradas pequenas lamelas cerosas. Pequenos depósitos de resinas são encontrados fixados nas paredes ou nas radículas.

As câmaras acessórias ou satélites do vestíbulo, contêm potes e, às vezes, pequenas lamelas cerosas mas não células vazias como em $P$. vicina, e não as interpretamos como um típico ninho falso, como nesta última. Além disso, a galeria de comunicação com a câmara de crias sai do vestíbulo principal e não de uma câmara secundária ou átrio, como em $P$. vicina. A galeria inicia-se em um orifício de $0,8 \mathrm{~cm}$ na parede posterior do vestíbulo, alarga-se para 1,0-1,5 cm, e estende-se por 10,0-20,0 cm ou mais, até atingir a parte lateral ou inferior da câmara de crias. As paredes são iguais àquelas do vestíbulo.

Câmaras de cria e alimento. A câmara de crias é semelhante à de $P$. vicina. Escavada no termiteiro, com ca. 25,0-30,0 cm de altura por 20,0-25,0 cm de diâmetro. As paredes são de terra compactada com resinas, com 0,2-0,3 cm de espessura. Os favos, horizontais, situados no centro da câmara e envolvidos por 23 camadas lamelares de invólucro; a camada externa de cerume marrom-escuro, ressecada e quebradiça, as internas mais moles e mais claras. Os casulos com ca. 0,65 x 0,38 cm de altura e diâmetro, respectivamente. Todo o conjunto sustentado por finos pilares de resina e terra.

Os potes de pólen, marrom-castanhos, com 1,5-2,0 cm de altura por 1,4-1,6 cm de diâmetro, situados, em massa compacta, com paredes geminadas, na parte lateral ou inferior do ninho. Os de mel, entretanto, um pouco maiores (1,8-2,2 x 1,5-1,7 cm), alojados em uma ou mais câmaras anexas à câmara de crias. Em um dos ninhos que estudamos, havia quatro pequenas câmaras com potes de mel, interligadas umas às outras, em sequiência, através de estreitas galerias (como em P. vicina, Fig. 17). A câmara mais afastada encontrava-se a cerca de $90,0 \mathrm{~cm}$ da câmara de crias.

A única outra espécie que sempre constrói câmaras acessórias para abrigar os potes de mel é $P$. vicina. Outra espécie que às vezes constrói essas câmaras é $P$. ailyae. Todas as demais espécies usualmente constróem apenas uma câmara para as crias e os potes de alimento.

Ninhos examinados. 188c, 189c, 190c - Lago Carimum, rio Trombetas, PA, Brasil, 56 ${ }^{\circ}{ }^{\prime} \mathrm{W}, 1^{\circ} 32$ 'S, 16-17.II.1979 (Camargo et al.); 235c, 241c, 242c - Livramento, rio Negro, AM, Brasil, 66¹1’20”W, 0¹9’S, 24-26.VII.1980 (Camargo, Mazucato); 268c - Acanga, $30 \mathrm{Km}$

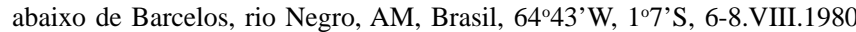
(Camargo, Mazucato); 271c, 273c, 274c - Caracaraí, RR, Brasil, 61º' W, 148’N, 13-15.VIII.1980 (Camargo, Mazucato); 275c, 276c - Mucajaí, BR174, RR, Brasil, 6057’W, 2³0’N, 15.VIII.1980 (Camargo, Mazucato); 291c - Lago Curiuaú, rio Negro, AM, Brasil, 611’'W, 155’S, 2425.VIII.1980 (Camargo, Mazucato); 768c - Santa Isabel do Rio Negro,
AM, 651'7”'W, 0²5’4”S, 11.VII.1999 (Camargo, Pedro, Mazucato); 788c - Tabocal, rio Uneiuxi, AM, 655'57.7”W, 0³4’45”S, 15.VII.1999 (Camargo, Pedro, Mazucato); 790c - Nazaré, rio Negro, AM, 654’37”W, 0³1’22”S, 15.VII.1999 (Camargo, Pedro, Mazucato); 809c - "Pai Raimundo”, rio Demini, AM, 62053'41”W, 0²4'1”S, 23.VII.1999 (Camargo, Pedro, Mazucato); 851c, 852c - São Francisco, Igarapé-Açu, rio Negro, AM, 6046’51”W, 249’58”S, 6-7.VIII.1999 (Camargo, Pedro, Mazucato).

Partamona vicina Camargo, 1980

(Figs. 1e, 3, 13-17, 32, 50)

Hábitat e substrato. É uma das espécies mais comuns ao longo de toda a Amazônia (Fig. 50). Nidifica em lugares sombreados da mata (Fig. 3), mas também é comum encontrá-la em regiões abertas, antrópicas e em clareiras ensolaradas. Nidifica em termiteiros arborícolas externos (entre os gêneros mais comuns estão Nasutitermes, Constrictotermes e Amitermes; Tabela I). Constrói ninhos solitários (Figs. 3, 14, 15) ou em agregações, às vezes em consórcios com outras espécies como, por exemplo, observamos em Tauari, PA, Brasil, juntamente com P. gregaria no mesmo termiteiro (Fig. 32), e em Muçum, PA, onde em um único termiteiro fixado em tronco de uma castanheira havia 20 ninhos de $P$. gregaria e 3 de $P$. vicina (ninhos 145c e 153c). Nas imediações do lago Uará, rio Solimões, AM, havia vários ninhos em consórcio com $P$. batesi em um mesmo termiteiro. Prefere os termiteiros de terra, mas às vezes é encontrada em termiteiros pretos de matéria orgânica. Nos cerrados do Brasil central é comum encontrá-la em termiteiros do tipo "bola" (Constrictotermes spp.), de terra (Fig. 15).

Estrutura de entrada. Tem a forma de uma concha acústica ou funil encurvado, pouco se destacando do substrato. Apresenta fortes estrias dispostas radialmente (Figs. 1e, 13, 16), que se estreitam para o interior do funil até o orifício de comunicação com o vestíbulo (Fig. 1e). São construídas basicamente de terra, com poucas aplicações de resinas. Geralmente da mesma cor que o substrato (acinzentadas), ou um pouco mais claras (amarelo-pardo), indicando que a terra pode ser transportada das adjacências. A textura da superfície é bastante rústica; as bolotas de terra são aplicadas irregularmente, recebendo pouco polimento. $\mathrm{O}$ tamanho varia, chegam a ca. 10,0-15,0 cm de altura por 10,0-12,0 cm de largura; o orifício de comunicação com o vestíbulo com 1,0-1,2 cm de diâmetro. Difere da entrada de $P$. mourei por apresentar as rampas suavemente encurvadas em direção ao orifício de entrada, sem formar ângulo no rebordo inferior, e também pela forma das estrias (Fig. 1e). Não há estruturas tubulares na parte inferior da entrada ou, quando existem, são pouco conspícuas.

Vestíbulo. Em P. vicina há duas câmaras vestibulares, um vestíbulo normal, contíguo à entrada, como aquele descrito para as demais espécies, e um segundo vestíbulo ou átrio (conforme relatado por CAMARGo 1980 e reproduzido por RouBIK 1989). O primeiro vestíbulo é preenchido por grossas radículas de terra e resinas (muito mais terra do que resinas, como aquelas de $P$. mourei); freqüentemente, na parte inferior deste vestíbulo, há um longo canal que, às vezes, se estende por $70,0 \mathrm{~cm}$ ou mais (com 2,0-3,0 cm de diâmetro), com o lume vazio, ou com 
pequenas lamelas cerosas, células e pequenos potes vazios (Fig. 17). A segunda câmara ou átrio, sempre na parte superior do vestíbulo, conecta-se com este por uma curta e larga galeria. O átrio é preenchido, invariavelmente, por lamelas cerosas (marrom-avermelhadas), alvéolos de cria, distribuídos irregularmente, e pequenos potes, ambos vazios ou com substância aquosa ácida. Interpretamos o átrio, dado o seu conteúdo, como um ninho falso, conforme comentários no item Câmaras Vestibulares (p. 318) e em CAMARGo (1980). Na parte inferior do átrio há um pequeno orifício com ca. 0,8 cm que dá acesso à galeria de comunicação com o ninho. Este padrão de distribuição das câmaras, galerias e conteúdo, foi constante em todas as dezenas de ninhos que estudamos, especialmente os da região do médio e baixo Tapajós, PA e região de Aragarças, GO (conforme Fig. 17), isto é, o átrio sempre na parte superior do vestíbulo.

Câmara de crias e alimento. O conjunto que constitui a câmara de crias e as câmaras com potes de armazenagem de alimento (Fig. 17) é idêntico ao de $P$. mourei. Uma câmara central (cerca de 18,0-20,0 cm de diâmetro) com os favos de crias envolvidos por 2-3 finas lamelas de invólucro (de cor marromavermelhada); os casulos com $0,54 \times 0,36 \mathrm{~cm}$; realeiras na periferia dos favos; os potes de pólen (1,5-2,0 x 1,5-1,8 cm, marromavermelhados) na parte inferior ou lateral; todo o conjunto transpassado por finos $(0,15-0,20 \mathrm{~cm}$ de diâmetro) pilares de terra e resinas. Os potes de mel, iguais no tamanho e cor aos de pólen, abrigados em uma ou várias câmaras acessórias, conectadas com a câmara principal por meio de estreitas galerias (Fig. 17).

Ninhos examinados. 20c, 21c - Barra do Garças, MT, Brasil, 1024.I.1971 (Camargo et al.); 82c - Vendaval, AM, Brasil, SA-19, 69 - 3h vi, Aldeia Ticuna, 18.I.1977 (Camargo, Mazucato); 84c - São Paulo de Olivença, AM, Brasil, SA-19, 69-4b, 19.I.1977 (Camargo, Mazucato); 92c - Vila Nova do Tonantins, AM, Brasil, SA-19, 68-3f ix, 22.I.1977 (Camargo, Mazucato); 122c, 128c - São Luís do Tapajós, PA, Brasil, 56¹4'W, 426'S, 14-17.i.1979 (Camargo et al.); 134c - Santa Maria Itaituba, PA, Brasil, 55⒌' W, 4¹3'S, 19-20.I.1979 (Camargo et al.); 145c, 153c - Mussum (sic $=$ Muçum), $15 \mathrm{Km}$ ao sul de Aveiro, margem esquerda do Tapajós, PA, Brasil, 55²5’W, 340’S, 24-28.I.1979 (Camargo et al.); 156c, 167c - Tauari, $80 \mathrm{~km}$ ao norte de Aveiro, margem direita do Tapajós, PA, Brasil, 557’W, 35'S, 29.I - 01.II.1979 (Camargo et al.) 169c, 173c - Alter do Chão, PA, Brasil, 54ํำ'W, 2³0'S, 3-4.II.1979 (Camargo et al.); 177c - Cachoeira da Porteira, PA, Brasil, 57' $\mathrm{W}$, 15'S, 9-12.II.1979 (Camargo et al.); 196c, 198c, 199c, 200c - Lago Uaicurapá, AM, Brasil, Paraná do Ramos, AM, Brasil, 56²45’W, 246’S, 20-21.II.1979 (Camargo et al.); 221c - Foz do rio Curicuriari, rio Negro, AM, Brasil, 66²9’W, 0¹3’30”S, 15-21.VII.1980 (Camargo, Mazucato); 264c - Acanga, $30 \mathrm{Km}$ abaixo de Barcelos, rio Negro, AM, Brasil, 6243’W, 105'S, 6-8.VIII.1980 (Camargo, Mazucato); 284c - Sta. Maria do Boiaçu, RR, Brasil, 614’'W, 0³0’20”S, 19-20.VIII.1980 (Camargo, Mazucato);

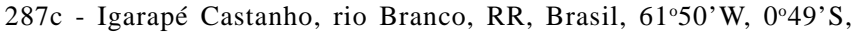
21.VIII.1980 (Camargo, Mazucato); 337c - Rio Ipixuna, AM, Brasil, 42 Km à montante do Tapauá, 6320'W, 60'S, 20.I.1986 (Camargo, Mazucato); 548c, Bacururu, rio Juruá, AM, Brasil, 66¹1'W, 345'S, 1.VIII.1993 (Camargo, Pedro, Mazucato); 593c - Lago Uará, rio Solimões, AM, Brasil, 6535’W, 241'S, 13.VIII.1993 (Camargo, Pedro, Mazucato); 602c - Maraã, rio Japurá, AM, Brasil, 65³5’W, 153’S, 17.VIII.1993 (Camargo, Pedro, Mazucato); 709c - Nova Xavantina, MT, Brasil, 03.IV.1996 (Mateus, Noll); 723c - São Jorge, rio Curicuriari (próx. a foz), margem esquerda, 6650’26”'W, 0¹3'8”S, 27.VI.1999 (Camargo, Pedro, Mazucato); 742c - Tapurucuara-Mirim, rio Negro, AM, 66²4’22.1”W, 0²5'17.6”S, 03.VII.1999 (Camargo, Pedro, Mazucato); 759c - Plano, margem esquerda do rio Negro, AM, 6559'24.6”W, 0¹8’36”S, 07.VII.1999 (Camargo, Pedro, Mazucato); 777c - Santa Izabel do Rio Negro, AM, 651'7”W, 0²5’4”S, 12.VII.1999 (Camargo, Pedro, Mazucato); 802c - Samaúma, rio Daraã, AM, 6445’35”W, 0²6’3”S, 19.VII.1999 (Camargo, Pedro, Mazucato); 822c - Tapera, Lago Caurés, rio Negro, AM, 62¹1'2”W, 1¹8’59”S, 28.VII.1999 (Camargo, Pedro, Mazucato); 853c, 858c - São Francisco, Igarapé-Açu, rio Negro, AM, 6046’51”W, 249’58”S, 07.VIII.1999 e 08.VIII.1999 (Camargo, Pedro, Mazucato).

\section{Partamona auripennis Pedro \& Camargo, 2003}

(Figs. 18, 19, 51)

Hábitat e substrato. Regiões de matas, no norte da Amazônia (Fig. 51). Só conhecemos um ninho desta espécie, de Tauari, PA, baixo Tapajós (168c); estava ocupando um pequeno termiteiro arborícola abandonado, sobre os galhos de uma árvore em igapó (Figs. 18, 19; Tabela I). Só uma pequena parte do termiteiro podia ser vista externamente, estava quase todo envolvido pela trama de túbulos e galerias construídos pelas abelhas (Fig. 19).

Estrutura de entrada. Em forma de concha, ovalada $(9,0 \mathrm{~cm}$ de altura por 5,4 cm de diâmetro), em baixo relevo, como uma colher bem profunda (5,0 $\mathrm{cm}$ de profundidade), na parte superior do ninho (Fig. 19). As rampas superior e inferior formando, praticamente, uma única superfície côncava, bem polida e revestida com aplicações de resinas enegrecidas; o orifício de entrada, bem circular, com $1,0 \mathrm{~cm}$ de diâmetro, na parte inferior da concavidade. A rampa inferior bem curta, horizontal, com $2,0 \mathrm{~cm}$ de profundidade, e a superior com 9,0 cm. Praticamente sem qualquer ornamentação, o rebordo apenas levemente revirado, não projetado, e com alguns alvéolos (Fig. 19). No conjunto, forma e textura, esta entrada é semelhante àquela de P. combinata (Figs. 1h, 22), com uma larga trama de túbulos na parte inferior.

Vestíbulo. Uma câmara preenchida com grossas estruturas (1,0-1,5 cm de diâmetro) radiculares de resinas, terra e material obtido do termiteiro; não havia potes ou lamelas cerosas, apenas alguns depósitos de resinas avermelhadas fixados às paredes. Aberturas nas paredes do vestíbulo comunicam-se com muitos canais, ou túbulos, que envolvem todo o ninho (Fig. 19). Um pequeno orifício, simples, sem gargalo em forma de garrafa, com $0,5 \mathrm{~cm}$ de diâmetro, na parte posterior do vestíbulo, dá acesso a uma pequena galeria $(1,4 \mathrm{~cm}$ de diâmetro por $10,0 \mathrm{~cm}$ de comprimento) de comunicação com a câmara de crias.

Câmara de crias e alimento. Com 18,0 cm de altura por 15,0 cm de diâmetro; no centro do termiteiro abandonado. As paredes, muito endurecidas, de terra e resinas, com 0,3-0,4 cm de espessura. Os favos (8 ao todo), horizontais, bem regulares com espaços de 0,3-0,4 cm; os casulos com 0,60 x 0,38 cm; as realeiras, na periferia dos favos, com 0,80 x $0,65 \mathrm{~cm}$. O invólucro com 3-4 camadas de finas lamelas envolvendo os favos de cria; as camadas mais externas, de terra e cerume, ressecadas e quebradiças; as internas cerosas e moles. Todo o conjunto transpassado por pilares permanentes de terra e resinas. Os potes de mel e pólen, na parte inferior do ninho, ovais, de cor marrom-avermelhada, com 1,7-1,8 x 1,5 cm, intercalados, sem 
nenhuma distinção entre eles.

Ninhos examinados. 168c - Tauari, PA, margem direita do rio Tapajós, 557’W, 35'S, 29.I-1.II.1979 (Camargo et al.).

Partamona combinata Pedro \& Camargo, 2003 (Figs. 1h, 22-24, 51)

Hábitat e substrato. É um habitante típico dos cerrados do Brasil central (Fig. 51); nidifica, preferencialmente, em termiteiros arborícolas externos do tipo "cabeça de negro" (Fig. 23), de matéria orgânica, enegrecidos. As espécies hospedeiras mais comuns são: Nasutitermes cf. kenneri Snyder \& Emerson, 1949, Microcerotermes cf. strunki (Sorensen, 1884) e Microcerotermes spp. (Tabela I).

Estrutura de entrada. Algumas entradas em forma de triângulo isósceles e outras bem ovaladas, formando uma concha bem rebaixada, usualmente na região equatorial do ninho (Figs. 1h, 22). A rampa inferior plana, ou formando uma única superfície côncava com a contra-rampa (Fig. 24). Toda a superfície das rampas muito bem polida e lisa, enegrecida e constituída de resinas e material obtido do substrato. Sem rebordo e sem qualquer ornamentação; com 7,0-8,0 cm de altura por 3,5-4,5 cm de largura e 4,0-5,0 cm de profundidade; o orifício de entrada com 1,0-1,2 cm de diâmetro, bem circular, e situado na parte proximal da rampa inferior (Figs. 1h, 22). Abaixo e nos lados da entrada, numerosas protuberâncias formando túbulos (como é usual em muitas espécies de Partamona) que se confundem com a textura do substrato. Internamente, esses túbulos formam um emaranhado de canais que se comunicam com o vestíbulo. Toda a estrutura da entrada bem endurecida pela presença de resinas e não solúvel em água. No conjunto, praticamente idêntica à entrada de $P$. auripennis.

Vestíbulo. Não constitui uma câmara bem delineada como nas espécies anteriormente descritas. A comunicação com a câmara de crias é feita através de uma larga galeria $(1,0-1,5 \mathrm{~cm}$ de diâmetro), que se inicia na parede posterior do vestíbulo, sem formar gargalo à sua entrada (Fig. 24). As estruturas radiculares, de terra e resinas, anastomosadas, são muito espessas (0,5-3,0 cm de diâmetro) e fortemente ligadas às paredes do vestíbulo (Fig. 24), diferentemente de outras espécies (por exemplo: P. vicina, $P$. mourei, $P$. mulata e $P$. testacea), onde são apenas levemente conectadas ao substrato, de maneira que todo o conjunto pode ser facilmente retirado sem danos. É freqüente encontrar pequenos potes $(0,6-0,9 \mathrm{x}$ 0,4-0,6 cm) vazios e com as paredes ressecadas, fixados nas radículas (Fig. 24). Não há lamelas cerosas ou qualquer outra estrutura no vestíbulo, apenas alguns depósitos de resinas.

Câmara de crias e alimento. A câmara, como nas demais espécies de Partamona, é pequena; no ninho representado na Fig. 24, tem 16,0 cm de altura por $11,0 \mathrm{~cm}$ de diâmetro. As paredes, rústicas e revestidas com resinas misturadas ao material raspado do próprio substrato. Os casulos com 0,62 x 0,34 cm; não foram observadas realeiras. Três a cinco camadas de invólucro envolvem os favos. As lamelas externas, de cerume e resinas, ressecadas e quebradiças; as internas, cerosas, moles e de cor amarelo-parda. Os potes de mel e pólen (1,4-1,8 x 1,0-1,2 cm) com as paredes geminadas e formando uma massa compacta na parte inferior do ninho, por fora do invólucro. A cor do cerume dos potes, como aquela do invólucro. Todo o conjunto sustentado por pilares permanentes de terra e resinas. Outros detalhes podem ser vistos na Fig. 24.

Ninhos examinados. 4c - Aragarças, GO, Brasil, 10-24.I.1971 (Camargo, et al.); 37c - Conceição das Alagoas, MG, Brasil, 29.III.1973 (Camargo, Terada, Schiavoni, Penha); 52c, 53c - ibidem, 20.IX.1973 (Penha); 304c - Gorotire (=Gradaús), PA, Brasil, SA-20, 51-8a, 20.VIII5.IX.1983 (Camargo); 500c - Reserva Krahó - Galheiros, 45 Km SE de Itacajá, TO, Brasil, 47²2’ W, 8²9'S, 21.I.1993 (Camargo, Tavares, Pedro).

Partamona chapadicola Pedro \& Camargo, 2003

(Figs. 2c, 25, 52)

Hábitat e substrato. Endêmica do leste do Pará, Maranhão, Piauí, até o noroeste da Bahia (Fig. 52); é comum nos cerrados e chapadas xéricas do nordeste do Maranhão. Nidifica em termiteiros ativos em ocos de troncos e galhos de árvores vivas (Fig. 25). As entradas estão localizadas em aberturas no tronco ou, mais freqüentemente, em "olhos" de cotos de galhos, às vezes vários ninhos em uma mesma árvore, como em $P$. ferreirai e $P$. nhambiquara, que são as únicas outras espécies conhecidas de Partamona que utilizam esse tipo de substrato.

Estrutura de entrada. Vista de frente, perfeitamente triangular (um triângulo isósceles de lados muito alongados), ou ovalada chegando a 10,0-15,0 cm de altura no rebordo externo (Figs. 2c, 25). O funil de entrada desce verticalmente até o orifício (ca.1,0$1,5 \mathrm{~cm}$ de diâmetro) de comunicação com o vestíbulo. A rampa superior forma uma abóbada suave com cerca de 12,0-13,0 cm do ápice até o orifício de entrada, mas apenas metade a um terço dessa extensão (ca. 8,0 cm) fica visível em vista frontal. A rampa inferior também é vertical e termina abruptamente em ângulo agudo e projetado no bordo externo, formando duas ou três pequenas protuberâncias (Figs. 2c, 25). Toda a estrutura é construída de material do termiteiro, terra e resinas; é bem endurecida pela forte presença de resinas e não solúvel em água. As rampas são bem polidas e alisadas e com um fino revestimento de argila de cor salmão ou cinza (como aquelas de $P$. gregaria e $P$. batesi). O rebordo não é saliente, porém com alguns alvéolos e revestimento como o das rampas (Figs. 2c, 25). Em uma das entradas estudadas (ninho 487c, Itacajá, TO, Brasil), o rebordo era bem ornamentado, com muitos alvéolos, formando entre eles estruturas semelhantes a radículas anastomosadas, com pequenos ramos projetados do substrato, de maneira muito semelhante às radículas que ornamentam as entradas de P. gregaria (Fig. 35). É bem possível que as estruturas radiculares anastomosadas que ornamentam as entradas das espécies desse grupo [itens Forma da Entrada (p. 317, Alvéolos, Ornamentação radicular) e Análise Filogenética, p. 321 e Fig. 58] derivem das saliências que ficam entre os alvéolos. Sempre na parte inferior da entrada, há um emaranhado de túbulos de terra e resinas (Fig. 25), como aqueles descritos para $P$. ferreirai. 
Vestíbulo. Uma só câmara, no lado externo do tronco, envolvida pelos túbulos de terra e resinas, que se vê externamente (Fig. 25). O interior da câmara preenchida com grossas radículas (0,5-1,5 cm de diâmetro) pardo-enegrecidas, de terra e resinas. Não temos observações sobre a presença de potes e nem sobre a galeria de comunicação com a câmara de crias.

Câmara de crias e alimento. Não há informações.

Ninhos examinados. 315c - Timon, MA, Brasil, 4.III.1984 (Camargo, Mazucato); 487c - Reserva Krahó - Galheiros, 45 Km SE de Itacajá, TO, Brasil, 47²2’W, 8²9'S, 18.I.1993 (Camargo, Tavares, Pedro); 663c, 665c - 39 Km S de Chapadinha, MA, Brasil, 43³0’W, 45'S, 13.XI.1994 (Camargo, Pedro); 675c - Lizarda, TO, Brasil, 444’ 'W, 9³6’'S, 18.XI.1994 (Camargo, Pedro).

Partamona nhambiquara Pedro \& Camargo, 2003 (Figs. 2d, 26, 52)

Hábitat e substrato. Ocorre nos cerrados do centro-oeste do Brasil (Fig. 52). Nidifica em termiteiros ativos em ocos de árvores vivas (em Callisthene sp., Vochysiaceae, no ninho estudado em Xavantina) (Fig. 26; Tabela I).

Estrutura de entrada. Muito semelhante à entrada de $P$. chapadicola quanto à ornamentação e formato das rampas (Fig. 26), o funil bem vertical, bastante profundo. A rampa inferior bem convexa, vertical, com cerca de $6,0 \mathrm{~cm}$ do bordo até o orifício de entrada, de modo que o orifício não pode ser visto externamente; a contra-rampa, suavemente côncava, com ca. 12,0 cm do ápice ao orifício de entrada e 4,0 cm de largura no bordo (Fig. 2d). Toda construída de terra e resinas; a superfície das rampas, rústica e revestida com argila grosseira, de cor palha; a metade superior da contra-rampa e a margem do rebordo, ao redor de toda a entrada, crivadas de alvéolos profundos, com diâmetros de ca. 0,4-0,8 cm, bastante semelhantes àqueles das entradas de $P$. ferreirai e, especialmente, de $P$. chapadicola. Um emaranhado de túbulos de terra e resinas, formam uma grande massa que se estende a $20-40 \mathrm{~cm}$ abaixo da estrutura de entrada (Fig. 26).

Vestíbulo. Uma câmara, situada no lado externo do tronco da árvore e envolvida pelo emaranhado de túbulos que se estendem largamente abaixo da entrada e com os quais se comunica através de inúmeros canais, como em P. chapadicola e $P$. ferreirai. As estruturas radiculares, pardo escuras, de terra e resinas que preenchem o vestíbulo, são grossas (0,5-2,0 $\mathrm{cm}$ de diâmetro, ou mais) e firmemente conectadas às paredes do vestíbulo, como em P. chapadicola. Na parte posterior do vestíbulo havia (no único ninho estudado com maiores detalhes) alguns pequenos potes $(1,0-0,8 \mathrm{~cm})$ de cor marrom escura e todos vazios. Lamelas cerosas ou outras estruturas não foram observadas. Não temos dados sobre a galeria de comunicação com a câmara de crias.

Câmara de crias e alimento. A única informação que temos (G.G. Azevedo e S. Mateus, com. pessoal), é que é constituída de uma única câmara com o conteúdo distribuído da forma usual para as espécies de Partamona; favos horizontais envolvidos por 3-4 camadas de invólucro e os potes de mel e pólen situados na parte inferior da câmara; todo o conjunto transpassado por pilares de terra e resinas. O cerume dos potes, favos e invólucro, de cor castanho-amarelada.

Ninhos examinados. A fotografia em que se baseia a Fig. 26 foi obtida por M. L. Oliveira em Guajará-Mirim, Serra dos Pacaás Novos, RO, Brasil, 21.I.1996. Os demais dados sobre o ninho foram obtidos de material (estrutura de entrada e vestíbulo) e informações fornecidas por G. G. Azevedo e S. Mateus, de um ninho por eles estudado em Nova Xavantina, MT, Brasil (Fazenda da Serra, Córrego do Lajedo, 52²7’32”W, 14³1'73”S), em 24.III.1998.

Partamona ferreirai Pedro \& Camargo, 2003 (Figs. 2a-b, 27-29, 52)

Hábitat e substrato. Esta espécie é endêmica das matas ao norte dos rios Negro e Amazonas (região Brasil / Guianas; Fig. 52). Nidifica em termiteiros ativos no interior de troncos e galhos de árvores vivas ou mortas e, às vezes, em termiteiros arborícolas externos. Em um dos ninhos estudados (252c), o hospedeiro foi identificado como Termes cf. hispaniolae (Banks, 1918). Os ninhos são solitários ou, mais comumente, em agregações (Fig. 27). É muito comum nas matas de igapó ao longo do rio Negro, onde o grande número de árvores mortas ou queimadas propicia substratos (ocos) em abundância para os térmitas e, por conseqüência, para as abelhas. Em um único hectare, na "Ponta Camucuri", margem sul do médio rio Negro (655'20”W, 0²0’2”S), encontramos 12 ninhos desta espécie, 5 em um único termiteiro (conjunto 761c), e em Tabocal, rio Uneiuxi, AM (3³4'45”'W, 655'57’'S, agregação 787c) havia 17 ninhos em consórcio com 4 ninhos de $P$. mourei, em um enorme termiteiro (18-20 $\mathrm{m}$ de altura) fixado externamente em um tronco de castanheira viva.

Estrutura de entrada. Como indicado nas Figs. 27-29, a estrutura de entrada é projetada sobre o substrato e com um conspícuo emaranhado de túbulos na parte inferior. Vista de frente tem o formato aproximado de um triângulo equilátero. Em perfil, constitui um profundo funil (ca. 8,0-10,0 cm de profundidade em algumas entradas) com a rampa inferior praticamente horizontal e lisa, e a contra-rampa côncava e crivada de profundos alvéolos distribuídos irregularmente (Figs. 2a-b, 28, 29; item Forma da entrada: Alvéolos, p. 317); alguns desses alvéolos, às vezes, têm comunicação com as estruturas tubulares que envolvem a entrada. O orifício de entrada, situado bem no fundo do funil, com 1,0-1,5 cm de diâmetro. A altura externa da boca por volta de 8,0-13,0 cm, e a largura 6,0-10,0 cm. As entradas dos ninhos da população da região do rio Trombetas, PA, são desprovidas de rebordo revirado (Figs. 2a, 29); naquela da região do rio Negro, entretanto, há um pequeno rebordo revirado, às vezes formando pequenas estrias longitudinais (Fig. 2b, 28). É provável mesmo que se tratem de espécies diferentes, como suspeitado por Pedro \& Camargo (2003). As entradas são construídas, basicamente, com material obtido do próprio termiteiro (matéria húmica, enegrecida), terra e resinas. As rampas são bem alisadas e com fino revestimento de silte ou argila esbranquiçada. O revestimento de argila atinge mais o rebordo e a parte apical das rampas, de modo que o 
fundo do funil e os alvéolos, onde predomina o revestimento com resinas enegrecidas, ficam em forte destaque.

Vestíbulo. Constituído de uma única câmara, com 10,0-15,0 cm de altura, como aquela de P. pearsoni (Fig. 31), preenchida pelas estruturas radiculares anastomosadas, de terra e resinas, de cor pardo-enegrecida. As radículas com 0,2-1,0 cm de diâmetro e firmemente conectadas às paredes do vestíbulo. $\mathrm{O}$ vestíbulo, usualmente, fica na parte externa do tronco da árvore ou do termiteiro, e comunica-se com o emaranhado de canais que, vistos externamente, formam uma grande massa de projeções tubulares enegrecidas (Figs. 27-29). Geralmente, fixados nas radículas ou nas paredes do vestíbulo, há pequenos potes (1,0-1,8 x 0,8-1,0 cm), marrom-amarelados contendo substância aquosa ácida ou, às vezes, mel, ou pólen e mel misturados. Há, também, pequenos depósitos de resinas. Nunca observamos lamelas de cera como aquelas do vestíbulo de $P$. vicina. A galeria de comunicação com a câmara de crias iniciase em uma pequena projeção, em forma de gargalo de garrafa, com um orifício de 0,8-0,9 cm de diâmetro, como aquele indicado na Fig. 31. Este caráter ocorre também em várias outras espécies (Tabela III). A galeria tem 1,0-1,5 cm de diâmetro, as paredes com 0,3-0,4 cm de espessura, como aquelas do vestíbulo, com extensão variável, e termina na parte superior, inferior ou lateral da câmara de crias.

Câmara de crias e alimento. Uma única câmara de cerca de $18,0-25,0 \mathrm{~cm}$ de altura, abriga os favos de cria (horizontais) e os potes de mel e pólen, como usualmente na maioria das espécies de Partamona. Casulos com ca. 0,60 x 0,35 cm; realeiras, na borda dos favos com 0,9 x 0,6 cm; espaço entre os favos, 0,35$0,50 \mathrm{~cm}$. Pequenas lâminas cerosas constituem o invólucro mas, às vezes, não envolvem todos os favos; algumas lamelas do invólucro são de terra e resinas. Os potes de mel e pólen com 1.3-1.8 x 1,0-1,2 cm situados, em conjunto, com paredes geminadas, na parte inferior da câmara de crias. Todo o conjunto transpassado e sustentado por finos pilares $(0,2-0,3 \mathrm{~cm}$ de diâmetro) de terra e resinas. As paredes da câmara constituídas de material do substrato e resinas, e muito irregulares, acompanhando as galerias do termiteiro. O cerume dos potes, favos e invólucro, bem amarelado.

Ninhos examinados. 181c, 182c, 183c, 184c, 186c - Lago Água

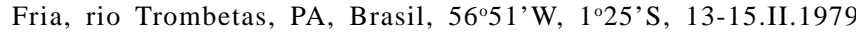
(Camargo et al.); 250c, 251c, 252c - Foz do rio Daraã, rio Negro, AM, Brasil, 47³0’W, 0²5'S, 2-4.VIII.1980 (Camargo, Mazucato); 293c Lago Curiuaú, rio Negro, AM, Brasil, 61¹3’W, 1º55’S, 24-25.VIII.1980 (Camargo, Mazucato); 651c - Reserva Praia Grande, rio Negro, AM, 60³2'W, 32'S, 18.VIII.1994 (Pedro); 747c - Tapurucuara-Mirim, rio Negro, AM, 66²4'22.1”W, 0²5'17.6”S, 02.VII.1999-04.VII.1999 (Camargo, Pedro, Mazucato); 761c (agregação) - Ponta Camucuri, Carixeno, margem direita do rio Negro, AM, 65⒌'20”W, 0²0'2”S, 08.VII.1999 (Camargo, Pedro, Mazucato); 767c - Ilha de Trindade, próx. Massarabi, rio Negro, AM, 6558'40”W, 0¹9’S, 09.VII.1999 (Camargo, Pedro, Mazucato); 787c (agregação) - Tabocal, rio Uneiuxi, AM, 655'57.7”'W, 3034'45”'S, 15.VII.1999 (Camargo, Pedro, Mazucato); 795c - Nazaré (ilha em frente à comunidade), rio Negro, AM, 65ㅇ'37’W, 0³1’22”S, 16.VII.1999 (Camargo, Pedro, Mazucato); 819c - Tapera, lago Caurés, rio Negro, AM, 62¹1'2”W, 1¹8’59”S, 27.VII.1999 (Camargo, Pedro, Mazucato); 838c (agregação) - Santa Helena, Ponta do Gavião, rio Negro, AM, 62¹2’16”W, 1¹8’21”S, 31.VII.1999 (Camargo, Pedro, Mazucato); 839c, 841c - Igrejinha, lago Boari, rio
Negro, AM, 61¹8'2”W, 157’50”S, 02.VIII.1999 (Camargo, Pedro, Mazucato); 843c - São Pedro, foz do rio Paduari, rio Negro, AM, 6113'10”'W, 26'27”S, 03.VIII.1999 (Camargo, Pedro, Mazucato).

Partamona pearsoni (Schwarz, 1938)

(Figs. 2g, 30, 31, 36, 52)

Hábitat e substrato. Apresenta uma distribuição incomum; ocorre no norte do Amazonas, da região do alto rio Negro até o Amapá e Guianas e, a leste, até o Pará e Maranhão, Brasil (Fig. 52), principalmente em regiões de matas. É muito comum nas matas de igapó na região do médio e baixo rio Negro; nidifica, preferencialmente, em termiteiros arborícolas ativos de Nasutitermes cf. peruanus (Holmgren, 1910) (Figs. 30, 31) e menos comumente em termiteiros de Amitermes excellens (Tabela I). Os ninhos de $N$. cf. peruanus são aproximadamente esféricos (40,0-50,0 cm de diâmetro), pretos, cartonados e construídos na base de trama dos galhos de árvores vivas ou mortas e muito comuns nas matas de igapó da região do rio Negro. Só conhecemos ninhos de $P$. pearsoni dessa região; são, usualmente, solitários, e as entradas são sempre na base do termiteiro (Figs. 30, 31).

Estrutura de entrada. É uma das estruturas mais peculiares dentre as espécies de Partamona (Figs. 30, 31, 36). É construída de material obtido do substrato, terra e resinas, e revestida, externamente, por uma fina película de argila branca ou acinzentada e muito bem polida, como nas entradas de $P$. batesi e P. gregaria (item "Revestimento da estrutura de entrada," $p$. 318; Figs. 34-36). Tem a forma de uma concha acústica com $10,0-12,0 \mathrm{~cm}$ de altura por 8,0-10,0 de largura e finamente ornamentada, nos rebordos, por estruturas radiculares dispostas radialmente (Figs. 30, 36). A rampa superior ou contrarampa, apresenta ondulações ou estrias transversais, em alguns casos muito regulares (Figs. 2g, 36) e que terminam, embaixo, em uma pequena plataforma (Fig. $2 \mathrm{~g}$ ) que se estende ao longo da beirada posterior da fenda que dá acesso ao vestíbulo. $\mathrm{O}$ funil de entrada é vertical e bastante profundo (a rampa inferior com 2,5-3,0 cm de profundidade), e termina na estreita fenda (ca. 3,0 cm de largura no sentido transversal por 0,3-0,4 cm no sentido ântero-posterior) de comunicação com o vestíbulo (Fig. 2g).

Vestíbulo. Conforme indicado na Fig. 31; uma câmara com cerca de 10,0-18,0 cm de altura por 8,0-10,0 cm de diâmetro e preenchida por finas $(0,2-0,4 \mathrm{~cm}$ de diâmetro) estruturas radiculares de material obtido no substrato, terra e resinas pardoenegrecidas e, usualmente, com 3-4 pequenos potes (ca.1,0 x $0,8 \mathrm{~cm}$ ) vazios entremeados e pequenos depósitos de resinas. Não há lamelas cerosas ou câmaras adicionais. Na parte inferior, o vestíbulo comunica-se com inúmeros canais, que formam um emaranhado de túbulos, de terra e resinas, que se vê externamente, abaixo da estrutura de entrada (Figs. 30, 31). A galeria de comunicação com a câmara de crias inicia-se em forma de um pequeno gargalo de garrafa, com um orifício de ca. 0,8 $\mathrm{cm}$, na parede posterior do vestíbulo (Fig. 31).

Câmara de crias e alimento. Geralmente uma câmara esférica com cerca de 15-20 cm de diâmetro (Fig. 31). Os favos, 
horizontais, envolvidos por 3-4 lamelas de invólucro. Os casulos com 0,6 x 0,38 cm; espaço entre os favos, 0,4-0,5 cm. Os potes de mel e pólen, na parte inferior da região de crias, ou em pequenas câmaras acessórias amplamente interligadas (Fig. 31); cada pote com ca.1,5-1,8 cm de altura por 1,2-1,3 cm de diâmetro. Todo o conjunto sustentado por finos pilares de terra e resinas. O cerume do invólucro, células e potes, de cor castanhoamarelada, quase translúcida.

Ninhos examinados. 222c - Foz do rio Curicuriari, rio Negro AM, Brasil, 66²9’W, 0¹3’30”S, 15-21.VIII.1980 (Camargo, Mazucato), 2 ninhos; 245c - Foz do rio Marié, rio Negro, AM, Brasil, 66²6’30”W, 0²6’30”S, 26-27.VIII.1980 (Camargo, Mazucato); 249c - 257c, Foz do

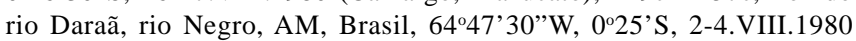
(Camargo, Mazucato); 292c - Lago Curiuaú, rio Negro, AM, Brasil,

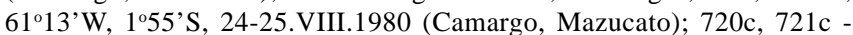
São Jorge, rio Curicuriari, margem esquerda, próx. a foz, AM, 6650’26”W, 0¹3'8”S, 26.VI.1999 (Camargo, Pedro, Mazucato); 729c - Camanaus, rio Negro, AM, 6656’4.8”W, 08'57.1”S, 30.VI.1999 (Camargo, Pedro, Mazucato); 760c - Plano, margem esquerda do rio Negro, AM, 6559'24.6”W, 0¹8’36”', 07.VII.1999 (Camargo, Pedro, Mazucato); 805c - Samaúma, rio Daraã, AM, 6445’35”W, 0²6’3”S, 20.VII.1999 (Camargo, Pedro, Mazucato).

Partamona gregaria Pedro \& Camargo, 2003 (Figs. 2e, 32, 35, 52)

Hábitat e substrato. Endêmica das matas da região dos baixos rios Tapajós e Xingu (Fig. 52). Prefere os lugares ensolarados. Nidifica em termiteiros arborícolas externos, freqüentemente em grandes agregações (em um único termiteiro, em tronco de castanheira, na localidade de Muçum, PA, em agregação em consórcio com P. vicina, 146c-147c, contamos 23 ninhos em atividade), principalmente em ninhos de Amitermes excellens, que constrói grandes estruturas em forma de estróbilo, de material húmico, preto, fixadas nos troncos das árvores e, comumente, nas paredes de habitações humanas (Fig. 32). É muito comum nas áreas antrópicas da região do baixo Tapajós. Utiliza também outros hospedeiros, como Nasutitermes cf. tatarendae (Holmgren, 1910) e $N$. acangussu Bandeira \& Fontes, 1979 (Tabela I).

Estrutura de entrada. A entrada é construída com uma mistura de material húmico, obtido do substrato, terra e resinas, e revestida por uma fina película de argila branca-acinzentada (Fig. 35), em forte contraste com o substrato enegrecido, como em $P$. batesi e $P$. pearsoni; porém, diferentemente destas, a rampa superior é larga e lisa e com as bordas externas ornamentadas com projeções radiculares (Fig. 35). Algumas entradas são muito grandes, chegando a 15,0-18,0 cm de altura. $O$ funil de entrada é bem vertical, como em $P$. batesi, $P$. nhambiquara, $P$. chapadicola e $P$. pearsoni, estreitando-se até formar o orifício (com 1,0-1,2 cm de diâmetro) de acesso ao vestíbulo. A rampa inferior, levemente convexa, com 3,0-4,0 cm de extensão e a superior, suavemente côncava, com 12,0-15,0 cm de altura (Fig. 2e, 35).

Vestíbulo. Praticamente não difere daquele descrito para $P$. pearsoni. Uma única câmara com 15,0-20,0 cm de altura por 10,0-12,0 cm de diâmetro, preenchida por finas estruturas radiculares (0,3-0,5 cm de diâmetro) anastomosadas, dois ou três pequenos potes vazios e alguns depósitos de resinas. Não observamos, em nenhum dos ninhos, lamelas cerosas. O acesso à câmara de crias se dá através de uma galeria com 10,020,0 cm de extensão por 1,5-2,0 cm de diâmetro, e que se inicia na parede posterior do vestíbulo, em uma projeção em forma de gargalo de garrafa, com orifício de $0,7 \mathrm{~cm}$. Tanto as paredes do vestíbulo como as da galeria e as estruturas radiculares são de material raspado do substrato e resinas, e bem polidos. As galerias tubulares, anexas ao vestíbulo, são pouco conspícuas, quando existem.

Câmara de crias e alimento. Como em P. pearsoni. Uma câmara com 25,0-30,0 cm de altura por 20,0-25,0 cm de diâmetro; as paredes constituídas como as das galerias e vestíbulo, acompanhando as sinuosidades das galerias do termiteiro. Os favos na parte superior da câmara e envolvidos por 2-3 finas lamelas de invólucro; a camada mais externa ressecada e quebradiça. Os casulos com 0,65 x 0,35 cm; os potes de mel e pólen (ca.1,8 x 1,2 cm), com as paredes geminadas ou isolados, na parte inferior da câmara. Tanto o invólucro interno, como as células e potes, de cor marrom-castanha. Todo o conjunto sustentado por finos pilares comuns de terra e resinas.

Ninhos examinados. 115c - 120c - São Luís do Tapajós, PA, Brasil, 56¹4’W, 4²6’S, 14-17.I.1979 (Camargo et al.), 6 ninhos; 146c, 147c - Mussum (sic $=$ Muçum), $15 \mathrm{Km}$ sul de Aveiro, margem esquerda do rio Tapajós, PA, Brasil, 55²5’W, 340’S, 24-28.I.1979 (Camargo et al.), agregação com 23 ninhos em consórcio com P. vicina; 166c - Tauari, 80 Km ao norte de Aveiro, margem direita do Tapajós, PA, Brasil, 557’ W, 35'S, 29.I-1.II.1979 (Camargo et al.), 9 ninhos em consórcio com $P$. vicina; 193c - Serra de Parintins, rio Amazonas, AM, Brasil, 56²6’W, 2²8’S, 19.II.1979 (Camargo et al.); 194c, 195c, 197c -Lago Uaicurapá, Paraná do Ramos, AM, Brasil, 5645’W, 246’S, 20-21.II.1979 (Camargo, et al.); 866c - Vila Nova, rio Andirá, PA, Brasil, 56²7’W, 3³9’S, 2.II.2001 (Camargo), agregação com 8 ninhos.

\section{Partamona batesi Pedro \& Camargo, 2003} (Figs. 2f, 33, 34, 52)

Hábitat e substrato. Endêmica das matas da região de Tefé, AM, até o Acre (Fig. 52). Prefere lugares ensolarados. É a espécie mais conspícua nos roçados e nas matas de igapó da região de Tefé. Nidifica em termiteiros arborícolas ativos (que habitam madeira morta), com revestimento cartonado, liso, preto, de Nasutitermes acangussu (Fig. 33) e outras espécies de Nasutitermes. Geralmente constituem grandes agregações (às vezes 20 ninhos ou mais) em um único termiteiro, com as entradas muito próximas umas das outras e bem visíveis à longa distância (Fig. 33).

Estrutura de entrada. A entrada dos ninhos desta espécie (juntamente com as de $P$. gregaria e $P$. pearsoni) constitui uma das obras de arquitetura mais sofisticadas que conhecemos dentre os Meliponini. A parte externa constitui uma abertura vertical, longa e estreita, circundada por um amplo rebordo, de superfície bem polida, lisa e finamente revestida por uma delicada película de argila esbranquiçada, que termina em projeções semelhantes a radículas anastomosadas, formando diferentes desenhos (Fig. 34), em forte contraste com o substrato e com o fundo da abertura central, que são enegrecidos. São 
inteiramente construídas com material raspado do substrato, terra e resinas, muito endurecidas e não solúveis em água. O fino revestimento de argila esbranquiçada só atinge o rebordo e ornamentos; a rampa de pouso é mais enegrecida e bem polida com resinas e um revestimento escasso e muito fino de argila. As maiores entradas chegam a medir, externamente, até ca. 20,0 $\mathrm{cm}$ de altura por 10,0-12,0 cm de largura. As margens da concavidade da entrada são protuberantes. A contra-rampa é em forma de concha larga que se afunila para baixo verticalmente, terminando no orifício (0,8-1,5 cm de diâmetro) de acesso ao vestíbulo (Figs. 2f, 34). Abaixo da entrada e anexo ao vestíbulo há poucos túbulos, ou estão ausentes.

Vestíbulo. Constituído de uma única câmara, praticamente idêntica àquela de $P$. gregaria; com ca. 10,0-15,0 cm de altura por 8,0-12,0 cm de diâmetro; as estruturas semelhantes a radículas anastomosadas, de material obtido do substrato, terra e resinas pardo-enegrecidas, que preenchem o lume do vestíbulo, são relativamente delgadas (0,4-1,0 cm de diâmetro) e fortemente conectadas às paredes deste. As paredes da câmara, bastante irregulares, acompanhando as reentrâncias das galerias do termiteiro e revestidas com resinas enegrecidas. Em alguns ninhos encontramos um ou outro pote vazio, ou com mel ou pólen, mas nunca vimos lamelas cerosas. A galeria de comunicação com a câmara de crias, assim como em $P$. gregaria, $P$. pearsoni, $P$. ferreirai e $P$. epiphytophila, inicia-se em uma projeção em forma de gargalo de garrafa, com um orifício de $0,7-0,8 \mathrm{~cm}$, na parede posterior do vestíbulo. A galeria com 1,5-2,0 cm de diâmetro, e com paredes iguais àquelas do vestíbulo, prolonga-se por 10,0-20,0 cm até se abrir na câmara de crias.

Câmara de crias e alimento. Uma só câmara, com 20,0-25,0 cm de altura e diâmetro; semelhante àquela de $P$. pearsoni (Fig. 31), porém muito irregular e com muitas reentrâncias e canais nas paredes, acompanhando as galerias do termiteiro. Os favos são horizontais, normais, mas, freqüentemente, não há lamelas de invólucro envolvendo-os. Casulos com 0,6 x 0,38-0,4 cm; realeiras, na periferia dos favos, com $1,0 \times 0,6 \mathrm{~cm}$. Os potes de mel e pólen (ca. 2,0-1,5 cm) dispersos irregularmente, ou em conjuntos situados na parte inferior e/ou lateral da câmara. Todo o conjunto sustentado por finos pilares de terra e resinas. As células, invólucro e potes, de cor castanho-amarelada.

Ninhos examinados. 110c - Tefé, AM, Brasil, SA-20, 65 - 3g.iii, 29.I.1977 (Camargo, Mazucato); 329c, 330c, 333c - Rio Ipixuna, 45 Km à montante de Tapauá, AM, Brasil, 6320'W, 6º's, 16-18.I.1986 (Camargo, Mazucato), os conjuntos 330c e 333c correspondem a agregações com 16 e 8 ninhos respectivamente; 370c - Arimã, Lago Jacaré, rio Purus, AM, Brasil, 6341’W, 543’S, 7.II.1986 (Camargo, Mazucato); 521c, 522c, 526c - Carauari, rio Juruá, AM, Brasil, 66' W, 453’S, 24.VII.1993 (Camargo, Pedro, Mazucato); 554c, 555c, 570c Forte da Graça, rio Juruá, AM, Brasil, 66º' 'W, 3³9’S, 2-6.VIII.1993 (Camargo, Pedro, Mazucato); o conjunto 570c constitui agregação com pelo menos 20 ninhos; 594c - Lago Uará, rio Solimões, AM, Brasil, 65³5’W, 241’S, 13.VIII.1993 (Camargo, Pedro, Mazucato), agregação com 15 ninhos; 623c - Alvarães, rio Solimões, AM, Brasil, 6450’W, 3¹3'S, 24.VIII.1993 (Camargo, Pedro, Mazucato), agregação com 4 ninhos; 626c, 627c - Nogueiras, lago de Tefé, AM, Brasil, 6448’ W, 3¹9’S, 25.VIII.1993 (Camargo, Pedro, Mazucato), agregações com 4 e 5 ninhos, respectivamente.
Distribuição geográfica. Novos registros: "Brasil, Acre, Acrelândia, 67²5'12”W, 104'48”, , 02-04.XI.2001, Oliveira, Morato \& Cunha” (agregação com 18 ninhos em termiteiro arborícola ativo). Este é o registro mais ao sul que se conhece para $P$. batesi (Fig. 52).

\section{Partamona ailyae Camargo, 1980}

(Figs. 1g, 3, 37-41, 53)

Hábitat e substrato. Ocorre desde as matas úmidas do sudoeste da Amazônia até os campos cerrados do Brasil central e regiões xéricas do Piauí (Fig. 53). Na Amazônia, os ninhos são usualmente encontrados em termiteiros ativos em tocos podres e secos de árvores (Figs. 3, 37), ou em termiteiros em ocos na base de troncos de árvores vivas (Fig. 38; Tabela I). Dos 16 ninhos estudados em região de mata úmida na Amazônia, 12 se encontravam em termiteiros em tocos podres (termiteiros de cor preta, constituídos de matéria vegetal decomposta; uma espécie identificada como Termes $c f$. medioculatus Emerson, 1925, ninho 148c, da região do baixo Tapajós, PA) e os outros 4, em termiteiros em ocos na base de troncos de árvores vivas. No Brasil central, região de cerrados, os ninhos de $P$. ailyae são comumente encontrados em termiteiros epígeos de "murundu" (Fig. 40, Syntermes molestus (Burmeister, 1839), ninhos 2c, 6c e 505c). Nas regiões xéricas do Piauí, os ninhos chegam a ser feitos em câmaras subterrâneas de termiteiros sob troncos (Fig. 39, ninho 666c) e em barrancos.

Os ninhos são, usualmente, solitários, um ninho em cada termiteiro; apenas em Aragarças, GO, observamos três ninhos em um único termiteiro sob as raízes de um angico (Piptadenia sp.). Dos 15 termiteiros inspecionados em uma pequena área nessa mesma região, 6 continham ninhos solitários de P. ailyae.

Estrutura de entrada. Nos ninhos estudados na Amazônia, em termiteiros pretos, a estrutura de entrada também é bem escura, devido em parte, ao material obtido do próprio substrato e misturado com resinas. Nas áreas secas do Brasil central e do nordeste, as entradas são principalmente de terra e da mesma cor que o termiteiro. A superfície das entradas é bastante rústica; percebem-se, nitidamente, pequenas manchas (0,2-0,3 cm de diâmetro), claras ou escurecidas, distribuídas irregularmente em toda a superfície (Fig. 41). Essas manchas correspondem, individualmente, às cargas de terra ou de resinas que são transportadas nas corbículas das operárias, de modo que, o resultado final é uma entrada com a superfície toda manchada (é possível distinguir, perfeitamente, o tamanho de cada carga, ou bolota de terra, trazida pelas operárias). Essa é uma das peculiaridades de $P$. ailyae. As entradas dos ninhos estudados na Amazônia são mais resistentes à água devido à maior porcentagem de resinas; aquelas estudadas na região de Aragarças, entretanto, são basicamente de terra e facilmente dissolvidas sob chuva forte. As entradas ficam bem projetadas sobre o substrato (Figs. 37-41). Em vista frontal têm a forma aproximada de um triângulo equilátero, com o rebordo da rampa inferior bem revirado, formando 3-5 fortes estrias longitudinais (Figs. 1g, 41). A rampa superior, em forma de concha acústica, com duas a três estrias a cada lado, e o ápice apenas crenulado. O tamanho varia de ca. 6,0 a 10,0 cm de altura, por 5,0 a 8,0 cm 
de largura (medidas externas). A rampa inferior, bem planahorizontal, com 2,0-3,0 cm de profundidade até o orifício de entrada; a contra-rampa com 5,0-10,0 cm de altura. O orifício de entrada no fundo do funil, com 1,5-1,8 cm de diâmetro (Fig. 1g). Não observamos estruturas tubulares abaixo da entrada em nenhum dos ninhos estudados.

Vestíbulo. Na maior parte dos ninhos estudados, o vestíbulo era constituído de uma câmara simples (14,0-40,0 cm de altura, por 5,0-10,0 cm de diâmetro), apenas preenchida pelas estruturas radiculares de terra e resinas; as radículas, enegrecidas, com 0,4-0,6 cm, ou mais de diâmetro; geralmente com 3-4 potes de cerume bem avermelhado, vazios ou com substância aquosa ácida, fixados nas radículas e, às vezes, depósitos de resinas. Em alguns ninhos, todavia, o vestíbulo inclui outras estruturas. No ninho 247c, por exemplo, da região da foz do rio Marié, AM, na parte superior do vestíbulo havia um pequeno conjunto de lamelas cerosas (como as do invólucro de crias), semelhantes àquelas construídas no vestíbulo e ninho falso de $P$. vicina, porém não havia potes ou células de crias vazios. No ninho 2c, estudado em Aragarças, GO, havia no vestíbulo, além de lamelas cerosas, vários potes, do mesmo tamanho que aqueles normais de armazenamento, alguns vazios e outros contendo pólen e mel. Um pequeno orifício com cerca de 0,6-0,8 cm de diâmetro, na parte látero-posterior da câmara, dá acesso à galeria de comunicação com a câmara de crias; não há projeção em forma de gargalo de garrafa. A galeria varia em extensão (5,0-50,0 cm) e diâmetro $(1,0-2,0 \mathrm{~cm})$ e tem as paredes revestidas com terra e resinas.

Câmara de crias e alimento. Inteiramente escavada no termiteiro, com 12,0-20,0 cm de altura e diâmetro. As paredes bastante irregulares, acompanhando as reentrâncias das galerias do termiteiro, delimitadas com resinas e material raspado do próprio substrato. Os casulos com $0,68 \mathrm{~cm}$ de altura por 0,39 cm de diâmetro; favos, horizontais, situados no centro do ninho, como em P. cupira (Fig. 45). Todo o conjunto envolvido por 34 finas camadas de lamelas cerosas, avermelhadas, e sustentado por pilares permanentes de terra e resinas. Na parte inferior dos favos, ou em duas a três câmaras conectadas à câmara de crias por estreitas galerias, estão situados os potes de mel e pólen; com 1,2-1,5 cm de altura por 1,0-1,2 cm de diâmetro, formam conjuntos compactos.

Uma das peculiaridades de $P$. ailyae é a cor do cerume, fortemente avermelhado, com o qual constrói os potes, invólucro e células. Câmaras suplementares com potes para armazenamento de alimento são também encontradas em $P$. vicina e $P$. mourei.

Ninhos examinados. 2c, 6c - Aragarças, GO, Brasil, 10-24.I.1971 (Camargo et al.); 114c - Tefé, AM, Brasil, SA-20, 65-3g.III, 29.I.1977 (Camargo, Mazucato); 148c - Mussum (sic = Muçum), $15 \mathrm{Km}$ ao sul de Aveiro, margem esquerda do Tapajós, PA, Brasil, 5525' W, 340'S, 2428.I.1979 (Camargo et al.); 163c, 164c - Tauari, PA, Brasil, $80 \mathrm{Km}$ ao

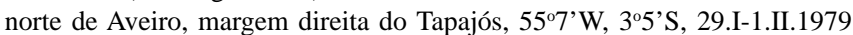
(Camargo et al.); 247c - Foz do Rio Marié, rio Negro, AM, Brasil, 66²6'30”'W, 0²6'30”'S, 26-27.VII.1980 (Camargo, Mazucato); 316c Serra do Uruçuí-Una, Bom Jesus, PI, Brasil, 4454’W, 96’'S, 4-10.III.1984 (Camargo, Mazucato); 362c - Arimã, rio Purus, AM, Brasil, 63ํ1'W, 543’S, 3.II.1986 (Camargo, Mazucato); 497c, 499c - Reserva Krahó,
Galheiros, 45 Km SE de Itacajá, TO, Brasil, 47²2’W, 8²9’S, 20.I.1993 (Camargo, Tavares, Pedro); 505c - 48 Km SE Sta. Filomena, PI, Brasil, 4538'W, 9¹8'S, 24.I.1993 (Camargo, Tavares, Pedro); 510c - $30 \mathrm{Km}$

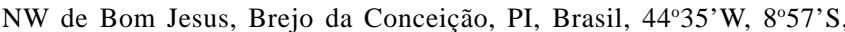
28.I.1993 (Camargo, Tavares, Pedro); 575c, 576c, 595c - Lago Uará, rio Solimões, AM, Brasil, 6535’ W, 241’S, 9-13.VIII.1993 (Camargo, Pedro, Mazucato); 601c - Maraã, rio Japurá, AM, Brasil, 65³5’W, 153’S, 17.VIII.1993 (Camargo, Pedro, Mazucato); 624c - Alvarães, rio Solimões, AM, Brasil, 645'', 313'S, 28.VIII.1993 (Camargo, Pedro, Mazucato); 630c, 633c - Nogueiras, Lago de Tefé, AM, Brasil, 6448’W, 3¹9'S, 2526.VIII.1993 (Camargo, Pedro, Mazucato); 666c, 670c - Brejo da Conceição, Município de Currais, 30 Km NW de Bom Jesus, PI, Brasil, 44³5'W, 857'S, 16.XI.1994 (Camargo, Pedro); 719c - São Jorge, rio Curicuriari, AM, 6650’26”W, 0¹3’8”S, 26.VI.1999 (Camargo, Pedro, Mazucato); 734c - Tapurucuara-Mirim, rio Negro, AM, 66 24'22”W, 0²5’17.6”, 01.VII.1999 (Camargo, Pedro, Mazucato); 823c - Lago Caurés, rio Negro, AM, 62¹1’2”W, 1¹8’59”S, 28.VII.1999 (Camargo, Pedro, Mazucato); 836c - Ponta do Gavião, rio Negro (ilha em frente à foz do rio Branco), AM, 62¹2’16”W, 1¹8’21”S, 31.VII.1999 (Camargo, Pedro, Mazucato).

\section{Partamona cupira (Smith, 1863)}

(Figs. 45, 53)

Hábitat e substrato. Região de campos cerrados de São Paulo, Minas Gerais e Goiás, Brasil (Fig. 53). Nidifica em termiteiros epígeos do tipo "murundu".

Estrutura de entrada. As anotações que seguem referem-se ao ninho 35c, de Conceição das Alagoas, MG. A entrada constituída apenas de uma pequena concavidade com $0,9 \mathrm{~cm}$ de diâmetro, com um pequeno rebordo rústico e com estrias longitudinais. Toda construída de terras e resinas (aparentemente a entrada havia sido destruída e não inteiramente reconstituída).

Vestíbulo. Uma câmara contígua à entrada, com $10,0 \mathrm{~cm}$ de altura por 6,0 cm de diâmetro; as paredes irregulares e compactadas com resinas. As radículas de terra e resinas sustentando alguns pequenos potes envelhecidos e vazios e depósitos de resinas (Fig. 45). Um orifício de 1,3 cm, na parte posterior do vestíbulo, dá acesso à galeria de comunicação com a câmara de crias. Esta se estende, horizontalmente, por cerca de $18 \mathrm{~cm}$ (1,5-2,0 cm de diâmetro), terminando na parte látero-inferior da câmara de crias (Fig. 45). Não havia galerias ou túbulos anexos ao vestíbulo.

Câmara de crias e alimento. No centro do termiteiro; $16,0 \mathrm{~cm}$ de altura por 11,0 cm de diâmetro; paredes irregulares e rústicas, constituídas de terra compactada com esparsas aplicações de resinas. Em alguns lugares havia pequenos depósitos de resinas fixados nas paredes (Fig. 45). Os favos de cria situados na parte central da cavidade e envolvidos por três a quatro camadas de invólucro. As camadas mais externas, constituídas de cerume e terra, pardo-enegrecidas e quebradiças; as camadas mais internas, de cerume, flexíveis e de cor marrom-amarelada. Os favos horizontais superpostos ou em espiral (Fig. 45), com espaços de aproximadamente $0,4 \mathrm{~cm}$; os casulos com 0,58-0,60 cm de altura por 0,35-0,37 cm de diâmetro; as realeiras com 0,92 x 0,48 cm. Uma célula real estava fixada no invólucro (Fig. 45), o que indica um período de desenvolvimento mais longo que o das operárias. Potes de mel e pólen com 1,0-1,4 cm de altura por 0,8-1,0 cm de diâmetro, situados na parte inferior do ninho; cor 
marrom-amarelada, como o invólucro interno. Todo o conjunto sustentado por pilares de terra e resinas, que atravessam os favos e o invólucro e se ligam às paredes da câmara (Fig. 45).

Ninhos examinados. Sem número - São João Del Rei, MG, Brasil, 59.I.1975 (Welthuis, Camargo); 35c - Conceição das Alagoas, MG, Brasil, 29.III.1973 (Camargo, Terada, Schiavoni, Penha); 463c - Lontra, MG, Brasil, 4423'W, 1536'S, 23.VII.1988 (Mazucato); 464c - Luislândia D’Oeste, MG, Brasil, 4535’W, 17²1'S, 25.VII.1988 (Mazucato).

\section{Partamona mulata Moure, in Camargo, 1980 (Figs. 42, 48, 53)}

Hábitat e substrato. Cerrados de Mato Grosso do Sul, Brasil, até a Bolívia (Fig. 53). Nidifica em termiteiros epígeos, ativos, do tipo "murundu" (Fig. 48) e em termiteiros fixados em troncos de árvores. SiLVESTRI (1902: 152) refere-se a um ninho desta espécie no solo, e outro no tronco de uma árvore à altura de 1,0 $\mathrm{m}$.

Estrutura de entrada. Muito simples; pequena abertura (1,52,0 cm de altura) cônica, embutida na superfície do termiteiro ou com algumas projeções estriadas no rebordo da rampa inferior (Fig. 42). É constituída de terra pura obtida do substrato e da mesma cor que este.

Vestíbulo. Temos dados mais completos apenas do ninho escavado por G. A. R. Melo. Neste caso, o vestíbulo constituise de uma câmara de $15,0 \mathrm{~cm}$ de altura por 5,0 cm de diâmetro, inteiramente escavada no substrato. As paredes apenas com leves aplicações de resinas. As estruturas radiculares, preenchendo todo o vestíbulo, constituídas de terra, da mesma cor que o substrato; as radículas muito grossas ou mesmo lamelares (com 2,0-3,0 cm de largura) e bastante rústicas, de forma semelhante àquelas encontradas em $P$. vicina e $P$. mourei. São apenas levemente conectadas às paredes do vestíbulo em um ou outro ponto, de maneira que todo o conjunto é facilmente destacável, sem danos. Não havia potes ou lamelas no vestíbulo. Um pequeno orifício com cerca de $0,7 \mathrm{~cm}$ de diâmetro, na parte mediana do vestíbulo, dá acesso à galeria de comunicação com a câmara de crias. A galeria, com cerca de 1,2 cm de diâmetro, percorre uma extensão de aproximadamente 15,0 cm até a câmara de crias.

Câmara de crias e alimento. Aproximadamente no centro do termiteiro, mais ou menos esférica, com 19,0 cm de diâmetro. As paredes levemente revestidas com resinas; os favos, horizontais, dispostos na parte central e envolvidos por 2-3 camadas de invólucro. As lamelas mais externas, mais enegrecidas, ressecadas e quebradiças. Os potes de mel e pólen na parte inferior da câmara; alguns isolados, outros com as paredes geminadas; medindo cerca de 1,5-1,6 cm de altura por 1,3-1,4 cm de diâmetro; de cor marrom-claro. Todo o conjunto do ninho, favos, potes e invólucro, transpassado por finos pilares de resinas e terra. Em todas as estruturas do ninho (exceto as radículas do vestíbulo), e também quanto ao substrato utilizado, $P$. mulata é praticamente idêntica à $P$. cupira, sua vicariante a leste.

Ninhos examinados. As informações aqui apresentadas, bem como as Figs. 42 e 48, foram baseadas nas fotografias obtidas por G.A.R. Melo, em Cuiabá, MT (5.II.1986) e por R. Ribon, nessa mesma localidade (19.VII.1997).
Partamona seridoensis Pedro \& Camargo, 2003

(Figs. 20, 21, 53)

Hábitat e substrato. Nidifica em termiteiros arborícolas externos, ativos, do tipo "bola”, construídos de terra e apoiados em saliências de troncos e galhos (Fig. 20). Estes termiteiros são muito comuns nos cerrados e áreas xéricas do nordeste do Brasil, área de ocorrência da espécie (Fig. 53). Os ninhos usualmente são solitários, um em cada termiteiro. LoRENzon et al. (1999) examinaram, na região de São João do Cariri, PB, 22 ninhos de Constrictotermes sp., dos quais 12 (6 ativos e 6 abandonados) estavam ocupados por $P$. seridoensis (= P. aff. nigrior).

Estrutura de entrada. Geralmente na parte inferior do termiteiro (Fig. 20); muito simples, embutida ou um pouco destacada da superfície do substrato, da mesma cor que este, e construída de terra praticamente pura, provavelmente obtida do termiteiro. Vista de frente, tem a forma aproximada de um triângulo equilátero, com 4,0-5,0 cm de altura, por cerca de 4,0 cm de largura (Fig. 21). Forma um pequeno funil; a superfície das rampas é rústica e granulosa; em direção ao ápice, a rampa inferior forma um rebordo, um pouco revirado, sulcado ou estriado longitudinalmente (Fig. 21), muito semelhante às entradas de $P$. mulata, $P$. ailyae e $P$. criptica. Não temos dados sobre as estruturas internas.

Ninhos examinados. 300c - $10 \mathrm{Km}$ ao norte de Urbano Santos, MA, Brasil, 8.XI.1982 (Camargo); 501c, 502c - 80 Km SW de Alto Parnaíba (25 Km E de Lizarda, TO), MA, Brasil, 46²8’W, 9³6’S, 22.I.1993 (Camargo, Tavares, Pedro).

\section{Partamona criptica Pedro \& Camargo, 2003} (Figs. 43, 53)

Hábitat e substrato. Matas atlânticas de São Paulo, Rio de Janeiro, Espírito Santo e Minas Gerais, Brasil (Fig. 53). Nidifica em termiteiros ativos em oco de tronco de árvore (I. Stanciola, inf. pessoal; Tabela I).

Estrutura de entrada. Em forma de uma pequena concha acústica, medindo, no rebordo, $4,0 \mathrm{~cm}$ de altura por $3,0 \mathrm{~cm}$ de largura. A rampa superior, ou abóbada, bem côncava e projetada em forma de teto. A rampa inferior, convexa, com o rebordo projetado formando algumas estrias longitudinais irregulares e rústicas (Fig. 43). Constituída basicamente de resinas enegrecidas, endurecidas e não pegajosas, de modo que, a rampa superior, mesmo de textura irregular, fica brilhante. $\mathrm{O}$ uso da terra é perceptível apenas na rampa inferior. Há, também, pequenas sementes e outras partículas misturadas à resina. A rampa inferior, até o orifício de entrada, $\operatorname{com} 2,0 \mathrm{~cm}$; a superior com $3,0 \mathrm{~cm}$. O orifício de entrada, um pouco irregular, com 1,1 cm de diâmetro.

Vestíbulo. Pequeno, com não mais que 7,0 cm de altura, preenchido com as estruturas radiculares anastomosadas usuais, semelhantes àquelas de $P$. helleri; constituídas de resinas e material escavado das lamelas do termiteiro, bem enegrecidas e duras. A radícula com maior diâmetro, em torno de $0,4 \mathrm{~cm}$. Na parte posterior do vestíbulo, um orifício com 0,6 cm de diâmetro, dá acesso à galeria (esta com 1,0-1,5 cm de diâmetro) de comunicação com a câmara de crias. Não havia 
potes ou lamelas cerosas. A borda do orifício é saliente, mas não projetada em forma de gargalo de garrafa. Várias galerias tubulares, construídas de terra e resinas, se projetam da parte inferior do vestíbulo, formando uma massa irregular, visível externamente (Fig. 43).

Não há outras informações sobre o ninho.

Ninhos examinados. As informações aqui relatadas referem-se a apenas um ninho coletado em Caeté, MG, Brasil, 21.III.1989 (I. Stanciola).

\section{Partamona rustica Pedro \& Camargo, 2003} (Fig. 53)

Hábitat e substrato. Regiões de campos cerrados do norte de Minas Gerais e sudoeste da Bahia, Brasil (Fig. 53). Nidifica em termiteiros arborícolas externos, ativos, e cumeeira de habitação humana (Tabela I), de acordo com M. Mazucato, que coletou material de alguns ninhos. Não há outras informações.

Ninhos examinados. 424c - Cônego Marinho, MG, Brasil, 44²5’W, 1518’S, 13-15.III.1988 (Mazucato); 439c, 460c - Lontra, MG, Brasil,

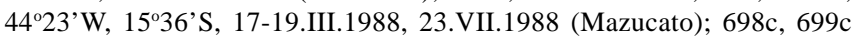
- Sto. Antônio, Cocos, BA, Brasil, 4440’W, 14²'S, 24-27.VII.1995 (Mazucato).

\section{Partamona helleri (Friese, 1900)} (Figs. 1c, 44, 46, 47, 54)

Hábitat e substrato. Ocorre nas matas atlânticas e áreas abertas do sudeste do Brasil, da Bahia até Santa Catarina (Fig. 54). Nidifica em uma vasta gama de substratos (Tabela I), mas em áreas sem influência antrópica, nas matas (matas atlânticas do sudeste do Brasil), nidifica principalmente sob raízes de epífitas (Fig. 46) (Ihering 1903, 1930; Marianno 1911; Ducke 1916; Camargo \& Pedro, obs. pessoais). É comum ver ninhos sob beirais e cumeeiras de casas (Fig. 47), em ninhos abandonados de "joão-graveteiro" (Phacellodomus sp., no sul de Minas Gerais e nordeste de São Paulo), buracos em paredes, em ocos de árvores e até ninhos totalmente livres, apenas apoiados sobre galhos de árvores. Esta é a única espécie do sudeste do Brasil que não nidifica em associação com termiteiros. Na região de Paraopeba, MG, entretanto, foram observados alguns ninhos no interior de termiteiros arborícolas ativos (Silveira, inf. pessoal), mas de uma população cujas operárias apresentam as asas mais claras que aquelas das populações mais a leste, e é possível que constitua uma espécie distinta. Neste texto, ambas as populações foram consideradas como $P$. helleri, até que a dúvida seja esclarecida.

Estrutura de entrada. Difere das de todas as demais espécies que ocorrem na região sudeste da América do Sul (espécies do grupo cupira), por não apresentar estrias longitudinais no rebordo inferior e pelo formato, em vista frontal, usualmente em triângulo equilátero com os cantos largamente arredondados (Figs. 1c, 44, 46, 47). Situa-se, quase sempre, na região equatorial do ninho. No bordo externo com 6,0-7,0 cm, tanto de altura como de largura. A profundidade, em torno de 5,0-6,0 cm na rampa inferior, e 10,0-12,0 cm na superior. As rampas (a inferior com uma inclinação, para dentro, de aproximadamente $45^{\circ}$ ) afunilam-se, gradualmente, até terminarem em um fundo arredondado, onde se situa o orifício de comunicação com o vestíbulo, com cerca de 1,0-1,5 cm de diâmetro (Fig. 1c). É construída inteiramente de terra fortemente compactada com resinas enegrecidas (de modo que não se dissolve com a água), com a superfície das rampas bem polida e lisa. Na rampa superior geralmente existem alguns alvéolos isolados ou enfileirados, no sentido transversal (Fig. 44), e que estão associados às estruturas tubulares que são construídas ao redor da entrada. Os fundos desses alvéolos são fechados à medida que o rebordo da entrada vai sendo ampliado (Fig. 44). Ao redor da estrutura de entrada e, às vezes, ao redor de grande parte do ninho, são construídas, com terra e resinas, estruturas tubulares que formam um emaranhado de canais interligados e com comunicação com o vestíbulo.

Vestíbulo. Uma câmara com 8,0-12,0 cm de altura por 6,0-7,0 de diâmetro, preenchida por estruturas semelhantes a radículas anastomosadas, constituídas de terra e resinas. As radículas com 0,4-0,6 cm de diâmetro; uma delas, usualmente, terminando em forma de cone junto ao orifício de entrada. Nos ninhos estudados, não notamos a presença de potes no vestíbulo. A comunicação entre o vestíbulo e a câmara de crias é feita através de um pequeno orifício (0,7-0,8 cm de diâmetro), com as bordas externas um pouco salientes e reviradas, lembrando um pequeno gargalo de garrafa, mas não forma um tubo como aquele de $P$. pearsoni, por exemplo, como indicado na Fig. 31. Segue-se ao orifício, uma pequena galeria de 1,2-1,3 cm de diâmetro, terminando na parte lateral da câmara de crias.

Câmara de crias e alimento. O ninho como um todo, como nas Partamona em geral, não é grande; mede, dependendo do substrato, em torno de 25,0-30,0 cm de diâmetro. É envolvido por grosso batume de terra e resinas, entremeado por labirintos de galerias. Uma única câmara, com 12,0-15,0 cm de diâmetro, abriga os favos de crias e os potes de mel e pólen. Os favos, horizontais superpostos, com espaços de cerca de $0,4 \mathrm{~cm}$, são sustentados por pilares comuns de terra e resinas, que atravessam todo o ninho, e por pequenos conectivos de cerume. Os casulos com 0,58-0,60 cm de altura por 0,35-0,40 cm de diâmetro. Os favos envolvidos por 2-3 finas lamelas cerosas de cor amarelo-ocrácea. Os potes de mel e pólen, da mesma cor, situados na parte inferior e laterais da câmara, com 1,2-1,4 cm de altura por 0,9-1,0 cm de diâmetro, aproximadamente.

Ninhos examinados. Vimos muitos ninhos de P. helleri em toda a região sudeste do Brasil, porém, estudados com mais detalhes foram apenas cinco: 26c - Ribeirão Preto, SP, Brasil, 7.VII.1971 (Camargo); 46c - Batatais, SP, Brasil, 23.III.1973 (Camargo, Zucchi); 635c - Ribeirão

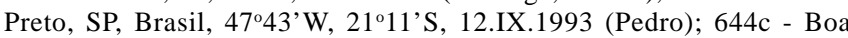
Sorte, MG, Brasil, 42³6’W, 1658'S, 22.VII.1994 (Mazucato).

Nota. Em 26.VI.1999, em viagem à região do alto Rio Negro, encontramos, nas margens do rio Curicuriari (6650'26”W, 0¹3'8”S) restos de um ninho de Partamona, há muito abandonado, tendo como substrato partes de um termiteiro e de um formigueiro (Azteca sp.), igualmente abandonados e pendurados em um galho de árvore. A concavidade de entrada desse ninho tem a forma muito semelhante àquelas de $P$. combinata e $P$. auripennis, porém bem mais profunda, e diferentemente destas, ornada nos lados com longas lamelas sobrepostas, como caixilho de persianas; o conjunto todo, medindo $20 \mathrm{~cm}$ de altura e construído de terra e resinas. Esta ornamentação é inusitada e singular, não compartilhada com nenhuma das espécies cujos ninhos são conhecidos, embora a forma da concha de entrada seja sugestiva de relações com espécies do grupo nigrior. Até que se encontre ninhos 
ativos, este é um caso que não pode ser esclarecido. Pode até mesmo ser uma espécie não reconhecida, ou faltando, na revisão de Pedro \& CAMARgo (2003).

Agradecimentos. Somos especialmente gratos aos Diretores e pesquisadores do Instituto Nacional de Pesquisas da Amazônia - INPA, Warwick E. Kerr, Enéas Salati, Roberto Vieira, José Alberto S. Nunes de Mello e Ozório J.M. Fonseca, que muito gentilmente viabilizaram todo o apoio logístico, e também financeiro algumas vezes, para a realização de diversas das expedições ao Amazonas, onde grande parte do material utilizado neste estudo foi coletado; sempre com muita cordialidade, colocaram a nossa disposição os barcos e tripulação. Ao Setor de Transportes dessa instituição que, com muita competência, sempre facilitou as soluções e removeu empecilhos. Aos comandantes e tripulação dos barcos pela dedicação e espírito cooperativo. As principais expedições ao Amazonas estão relacionadas abaixo, indicando a região, período, barco utilizado, tripulantes, colaboradores e instituição financiadora: 1) Solimões (10.I - 02.II.1977): barco “Marupiara” (INPA), Miguel Rodrigues de Souza (comandante, INPA), Demar Francisco Rodrigues (maquinista, INPA), Antonio Torquato de Oliveira (cozinheiro, INPA), José Fernandes Soares (marinheiro, INPA), Menderson Mazucato (técnico, USP). Financiamento: INPA, projetos especiais. 2) Tapajós, Trombetas, médio Amazonas, Lago Uaicurapá e rio Uatumã (igarapé Maripá) (04.I - 27.II.1979): barco “Marupiara” (INPA), Demar Francisco Rodrigues (comandante, INPA), Francisco Novaes de Andrade (cozinheiro, INPA), João Batista de Sá Rodrigues e Limoel Pereira Gomes (marinheiros, INPA), Menderson Mazucato (técnico, USP), Otoniel Rodrigues Lira, técnico (INPA), Wladimir dos Santos (fotógrafo). Financiamento: INPA, projetos especiais. 3) Rio Negro e rio Branco (30.VII - 28.VIII.1980): barco "Pyatã” (INPA), João Batista Rodrigues de Sá (comandante, INPA), Demar Francisco Rodrigues (maquinista, INPA), Geraldo Seabra da Silva (cozinheiro, INPA), Antonio Machado Gomes (prático em navegação no rio Negro), Silvia das Graças Pompolo (citogeneticista, UFV), Menderson Mazucato (técnico, USP), João F. de Araújo Mendonça (médico e auxiliar de campo). Financiamento: FAPESP (proc. 79/1014). 4) Rios Purus e Ipixuna (03.I - 22.II.1986): barco “Capitão Walter” (fretado, particular), Noronha Freitas de Souza (comandante), Marcos Antônio Freitas de Souza (maquinista), Orlandino Alves da Silva (prático, INPA), Antônio Torquato de Oliveira (cozinheiro, INPA), Gerhard Gottsberger (botânico, colaborador), J. Döring (fotógrafo), Marcos Vinícius B. Garcia (colaborador, INPA), Menderson Mazucato (técnico, USP). Financiamento: FAPESP (proc. 85/2842-7), CNPq (proc. 406235/84ZO). 5) Solimões, Juruá, Japurá (04.VII 01.VIII.1993): barco "Pium” (INPA), Raimundo Moreira de Carvalho (comandante, INPA), Cândido Garcia de Carvalho (maquinista, INPA), Antônio Torquato de Oliveira (cozinheiro, INPA), Hermógenes Augusto da Silva (marinheiro, INPA), Silvia Regina de Menezes Pedro (colaboradora, USP), Menderson Mazucato (técnico, USP). Financiamento: FAPESP (proc. 92/2732-0 ZO). 6) Rio Negro e afluentes (15.VI - 15.VIII.1999): barco "Uiara” (INPA), Lemoel Pereira Gomes (comandante, INPA), João de Jesus Costa (maquinista, INPA), Lúcio da Silva Gomes (mecânico, INPA), Vinícius Vasconcelos da Costa (marinheiro, INPA), Raimundo Laredo Smith (cozinheiro, INPA), Silvia Regina de Menezes Pedro (colaboradora, USP), Menderson Mazucato (técnico, USP), Gabriel A. R. Melo (colaborador). Financiamento: FAPESP (proc. 1998/11605-9). 7) Rio Andirá (29.I - 09.II.2001): barco “Amanaí” (INPA); nesta viagem participamos (JMFC) como convidados do INPA para prestar assistência aos índios andirás com relação a criação e identificação de Meliponini, todavia aproveitamos para obter dados sobre Partamona. Participaram desta viagem o comandante Lemoel Pereira Gomes, o mecânico Lúcio S. Gomes e o cozinheiro Raimundo L. Smith, além de vários outros funcionários, estudantes e pesquisadores do INPA.

Ao Professor Giovanni Onore, pelo convite e participação nos trabalhos de campo durante a viagem às cabeceiras do Napo e Coca, Equador (05-08.VI.1987), financiada pela Pontificia Universidad Catolica del Ecuador, Quito. Ao Dr. David W. Roubik, do Smithsonian Research Institute, pelo convite e colaboração nos trabalhos de campo durante a viagem ao Panamá (VIII/1985), pela leitura do texto e informações sobre a biologia de $P$. peckolti e sobre a ocorrência de $P$. grandipennis em Cerro Campana, Panamá. Ao Dr. Reginaldo Constantino (UNB) e Dra. Eliana M. Cancello (Museu de Zoologia de São Paulo), pela identificação dos Isoptera. A Gisele Garcia Azevedo, pelas informações e fotografias de ninhos de Partamona seridoensis e Partamona nhambiquara, Rute Magalhães Brito-Ribon e Gabriel A. R. Melo pelas fotografias de ninhos de Partamona mulata (Cuiabá-MT), Márcio L. Oliveira pelas fotos do ninho de P. nhambiquara, e Elder Morato e Márcio L. Oliveira pelas fotos de ninhos e informações sobre a ocorrência de P. batesi no Acre, além de informações sobre várias outras espécies de Partamona. Ao senhor José Amílcar Tavares Filho, técnico do Depto. de Biologia da FFCLRP, pelo auxílio na preparação, triagem do material da coleção da FFCLRP (RPSP) e atualização dos fichários sobre Meliponini.

Finalmente, um agradecimento especial ao Sr. Menderson Mazucato, técnico do Depto. de Biologia da FFCLRP-USP, atualmente aposentado, que dedicou sua vida profissional, com muita competência, à coleta, montagem, e organização de nossa coleção, e pela amizade e companheirismo durante as muitas viagens.

\section{REFERÊNCIAS}

Amorim, D. S. \& M. R. S. Pires. 1996. Neotropical biogeography and a method for maximum biodiversity estimation, p. 183-219. In: C. E. M. Bicudo \& N. A. Menezes (eds.). Biodiversity in Brazil, a first approach. São Paulo, CNPq, 326 p.

Bravo, F. 1992. Sistemática e distribuição de Parapartamona Schwarz (Hymenoptera, Apidae, Meliponinae). Revista Brasileira de Entomologia 36(4): 863-878.

Bravo, F. 1993. Descrição dos ninhos de Parapartamona zonata (Smith, 1854) e Parapartamona brevipilosa (Schwarz, 1948) (Hymenoptera, Apidae, Meliponinae) coletados nos Andes Equatorianos. Revista Brasileira de Entomologia 37(4): 779-785.

Brown JR., K. S. 1987. Biogeography and evolution of Neotropical butterflies. In: T. C. Whitmore \& G. T. Prance (eds.). Biogeography and Quaternary History in Tropical America. Oxford, Clarendon Press, 214 p.

Camargo, J. M. F. 1970. Ninhos e biologia de algumas espécies de Meliponídeos (Hymenoptera: Apidae) da região de Pôrto Velho, Território de Rondônia, Brasil. Revista de Biologia Tropical 16(2): 207-239.

Camargo, J. M. F. 1974. Notas sobre a morfologia e biologia de Plebeia (Schwarziana) quadripunctata quadripunctata (Hym., Apidae). Studia Entomologica 17(1-4): 433-470.

Camargo, J. M. F. 1980. O grupo Partamona (Partamona) testacea (Klug): suas espécies, distribuição e diferenciação geográfica (Meliponinae, Apidae, Hymenoptera). Acta Amazônica 10(4) supl., 175 p.

Camargo, J. M. F. 1996a. Meliponini neotropicais (Apinae, Apidae, Hymenoptera): biogeografia histórica. Anais do Encontro sobre Abelhas de Ribeirão Preto, SP. Ribeirão Preto, USP, 2: 107-121.

Camargo, J. M. F. 1996b. Meliponini neotropicais: o gênero Camargoia Moure, 1989 (Apinae, Apidae, Hymenoptera). Arquivos de Zoologia 33(2): 71-92.

Camargo, J. M. F. \& J. S. Moure. 1994. Meliponini neotropicais: os gêneros Paratrigona Schwarz, 1938 e Aparatrigona Moure, 1951 (Hymenoptera, Apidae). Arquivos de Zoologia 32(2): 33-109.

Camargo, J. M. F. \& J. S. Moure. 1996. Meliponini neotropicais: o gênero Geotrigona Moure, 1943 (Apinae, Apidae, Hymenoptera), com especial referência à filogenia e biogeografia. Arquivos de Zoologia 33(3): 95-161.

Camargo, J. M. F. \& D. A. Posey. 1990. O conhecimento dos Kayapó sobre as abelhas sociais sem ferrão (Meliponinae, Apidae, Hymenoptera): notas adicionais. Boletim do Museu Paraense Emílio Goeldi 6(1): 17-42.

Camargo, J. M. F. \& D. Wittmann. 1989. Nest architecture and distribution of the primitive stingless bee, Mourella caerulea (Hymenoptera, Apidae, Meliponinae): evidence for the origin of Plebeia (s.lat.) on the Gondwana continent. Studies on Neotropical Fauna \& Environment 24(4): 213-229.

Camargo, J. M. F.; D. A. Grimaldi \& S. R. M. Pedro. 2000. The Extinct Fauna of Stingless Bees (Hymenoptera, Apidae, Meliponini) in Dominican Amber: Two New Species and Redescription of the Male of Proplebeia dominicana (Wille and Chandler). American 
Museum Novitates 3293: $24 \mathrm{p}$.

ChittKa, L.; J. Schorn; J. M. de Souza; D. F. Ventura \& J. M. F. Camargo. 1997. The nest entrance signal of the Amazonian bees Partamona pearsoni - a case where insects design their own flight targets, p.107116. In: V. E. Kipуаткоv (ed.). Proceedings of the International Colloquia on Social Insects, vol. 3-4. St. Petersburg, Socium, $311 \mathrm{p}$

Coloma, L. A. R. 1986. Contribución para el conocimiento de las abejas sin aguijón (Meliponinae, Apidae, Hymenoptera) de Ecuador. Monografia para licenciatura em Ciências Biológicas. Pontificia Universidad Catolica de Ecuador, 146 p.

Coltorti, M. \& C. D. Ollier. 2000. Geomorphic and tectonic evolution of the Ecuadorian Andes. Geomorphology 32: 1-19.

Cracraft, J. 1985. Historical Biogeography and Patterns of Differentiation within the South American Avifauna: Areas of Endemism, p. 49-84. In: P. A. Buckley; M. S. Foster; E. S. Morton; R. S. Ridgely \& F. G. Buckley (eds.). Neotropical Ornithology. Ornithological Monographs, No. 36, Washington. D.C., The American Ornithologists' Union, $1041 \mathrm{p}$.

Cracraft, J. 1988. Deep-History Biogeography: Retrieving the Historical Pattern of Evolving Continental Biotas. Systematic Zoology 37(3): 221-236.

Cracraft, J. \& R. O. Prum. 1988. Patterns and processes of diversification: speciation and historical congruence in some neotropical birds. Evolution 42(3): 603-620.

Ducke, A. 1916. Enumeração dos Hymenopteros colligidos pela Comissão e Revisão das espécies de abelhas do Brasil, Commissão de Linhas Telegraphicas e Estrategicas de Matto Grosso ao Amazonas. Publicação no. 35, annexo 5, Hist. Nat. Zool., pp. 1177., figs. $13-25$ + errata.

Gonçalves, J. A. 1973. Ocorrência e abundância de abelhas indígenas no Estado do Ceará (Brasil). Boletim Cearense de Agronomia 14: $1-13$.

GonzÁLes, J. A. 1983-1984. Acerca de la regionalización de la nomenclatura maya de las abejas sin aguijón (Melipona $s p$ ) en Yucatán. Revista de Geografía Agrícola 5-6: 190-193.

Gonzáles-B, V. H. \& G. Nates-ParRa. 1999. Sinopsis de Parapartamona (Hymenoptera: Apidae: Meliponini), un género estrictamente andino. Revista da Academia Colombiana de Ciencias 23, supl. esp.: 171-179.

Hooghiemstra, H. \& T. Van Der Hammen. 1988. Neogene and Quaternary development of the Neotropical rain forest: the forest refugia hypothesis, and a literature overview. Earth - Science Review 44: 147-183.

Hoorn, C.; J. Guerrero; G. A. Sarmiento \& M. A. Lorent. 1995. Andean tectonics as a cause for changing drainage patterns in Miocene northern South America. Geology 23: 237-240.

IHERING, H. von. 1903. Biologie der stachellosen Honigbienen Brasiliens. Zoologische Jahrbücher. Abteilung für Systematik, Geographie und Biologie der Tiere 19(1904): 179-287.

IHERING, H. von. 1930. Biologia das abelhas melliferas do Brasil. Boletim Agrícola 31: 435-506, 649-714, figs. 1-22, pl.1 (tradução de H. von Ihering, 1903, por R. von Ihering e B. Sampaio de Corrêa).

KeRR, W. E. 1969. Some aspects of the evolution of social bees (Apidae). Evolutionary Biology 3: 119-175.

Kerr, W. E.; S. F. Sakagami; R. Zucchi; V. Portugal-Araújo \& J. M. F. CAmargo. 1967. Observações sobre a arquitetura dos ninhos e comportamento de algumas espécies de abelhas sem ferrão das vizinhanças de Manaus, Amazonas (Hymenoptera, Apoidea). Atas do Simpósio sobre a Biota Amazônica 5(zool.): 255-309.

Lorenzon, M. C. A.; A. G. Bandeira; H. M. Aquino \& N. MaracajÁ-Filho. 1999. Relationship between Partamona (Hym., Apidae) and Constrictotermes (Isop., Termitidae) in the semiarid region of Paraíba state, Brazil. Revista Nordestina de Biologia 13(1/2): 61-68.

Maddison, W. P. \& D. R. Maddison. 1992. MacClade, version 3.05. Sunderland, Sinauer Associates, Inc. Publishers.

Marianno, J. 1911. Ensaio sobre as Meliponidas do Brasil. Rio de
Janeiro, Edição do Autor, 140 p.

Michener, C. D. 1946. Notes on the habits of some Panamanian stingless bees (Hymenoptera, Apidae). Journal of the New York Entomological Society 54: 179-197.

Michener, C. D. 1974. The Social Behavior of the Bees. Cambridge, Harvard Univ. Press, xii +404 p.

Nates-ParRa, G. 1983. Abejas de Colombia: I. Lista preliminar de algunas especies de abejas sin aguijón (Hymenoptera, Apidae, Meliponinae). Revista de Biologia Tropical 31(1): 155-158.

Nates-Parra, G. \& O. I. Cepeda. 1983. Comportamiento defensivo en algunas especies de meliponinos colombianos (Hymenoptera: Meliponinae). Boletim do Departamento de Biologia da Universidad Nacional de Colombia 1(5): 65-82.

Nogueira-Neto, P. 1954. Notas bionômicas sobre Meliponíneos: III sobre a enxameagem. Arquivos do Museu Nacional 42: 419-451.

Parra, G. V. 1990. Bionomia de las abejas sin aguijón (Apidae, Meliponinae) del occidente Colombiano.Cespedesia 57-58:77-116.

Pedro, S. R. M. \& J. M. F. Camargo. 2003. Meliponini Neotropicais: o gênero Partamona Schwarz, 1939 (Hymenoptera, Apidae). Revista Brasileira de Entomologia 47(supl. 1): 1-117.

Ramos, V. A. \& A. Aleman. 2000. Tectonic Evolution of the Andes, p. 635-685. In: U. G. Cordani; E. J. Milani; A. Thomaz Filho \& D. A. Campos (eds.). Tectonic Evolution of South America, Rio de Janeiro, 31 $31^{\text {st }}$ International Geological Congress, $854 \mathrm{p}$.

Räsänen, M. E.; A. M., Linna; J. C. R. Santos, \& F. R. Negri. 1995. Late Miocene Tidal Deposits in the Amazonian Foreland Basin. Science 269: 386-390.

RAU, P. 1933. The Jungle bees and Wasps of Barro Colorado Island (with notes on other insects). Kirkwood, Missouri, $324 \mathrm{p}$.

Rau, P. 1943. Notes on the nesting habits of certain social and solitary bees of Mexico. Annals of the Entomological Society of America 36: 641-646.

RouBiK, D. W. 1979. Nest and colony characteristics of stingless bees from French Guiana (Hymenoptera: Apidae). Journal of the Kansas Entomological Society 52(3): 443-470.

RoubiK, D. W. 1983. Nest and colony characteristics of stingless bees from Panama (Hymenoptera: Apidae). Journal of the Kansas Entomological Society 56(3): 327-355.

RoubiK, D. W. 1989. Ecology and Natural History of Tropical Bees. New York, Cambridge University Press, $\mathrm{x}+514 \mathrm{p}$.

Roubiк, D. W. 1992. Stingless bees: a guide to Panamanian and Mesoamerican species and their nests (Hymenoptera: Apidae: Meliponinae), p. 495-524. In: D. Quintero \& A. Aiello (eds.). Insects of Panama and Mesoamerica. Selected Studies. Oxford, Oxford University Press, 692 p.

Schwarz, H. F. 1938. The stingless bees (Meliponidae) of British Guiana and some related forms. Bulletin of the American Museum of Natural History 74: 437-508.

Schwarz, H. F. 1948. Stingless bees (Meliponidae) of the Western Hemisphere. Bulletin of the American Museum of Natural History 90: 1-546 + xvii.

Silvestri, F. 1902. Contribuzione alla conoscenza dei Meliponidi del Bacino del Rio de la Plata. Rivista di Patologia Vegetale 10(1904): 121174 + Figs. 1-19, pls. 103

Swofford, D. L. 1993. PAUP - Phylogenetic Analysis Using Parsimony, version 3.1.1., Smithsonian Institution.

Villa, A. L. \& C. B. Vergara. 1982. Contribución al estudio de los hábitos de nidificación de algunas especies de abejas nativas sin aguijón (Hymenóptera, Apidae). Scientiae 1(2): 147-163.

WheELER, W. M. 1913. Notes on the habits of some central american stingless bees. Psyche 20(1): 1-9.

Wille, A. \& C. D. Michener. 1973. The nest architecture of stingless bees with special reference to those of Costa Rica (Hymenoptera, Apidae) Revista de Biologia Tropical 21(supl.1): 1-128.

Wille, A. \& E. Orozco. 1975. Observations on the founding of a new colony by Trigona cupira (Hymenoptera: Apidae) in Costa Rica. Revista de Biologia Tropical 22(2): 253-287. 

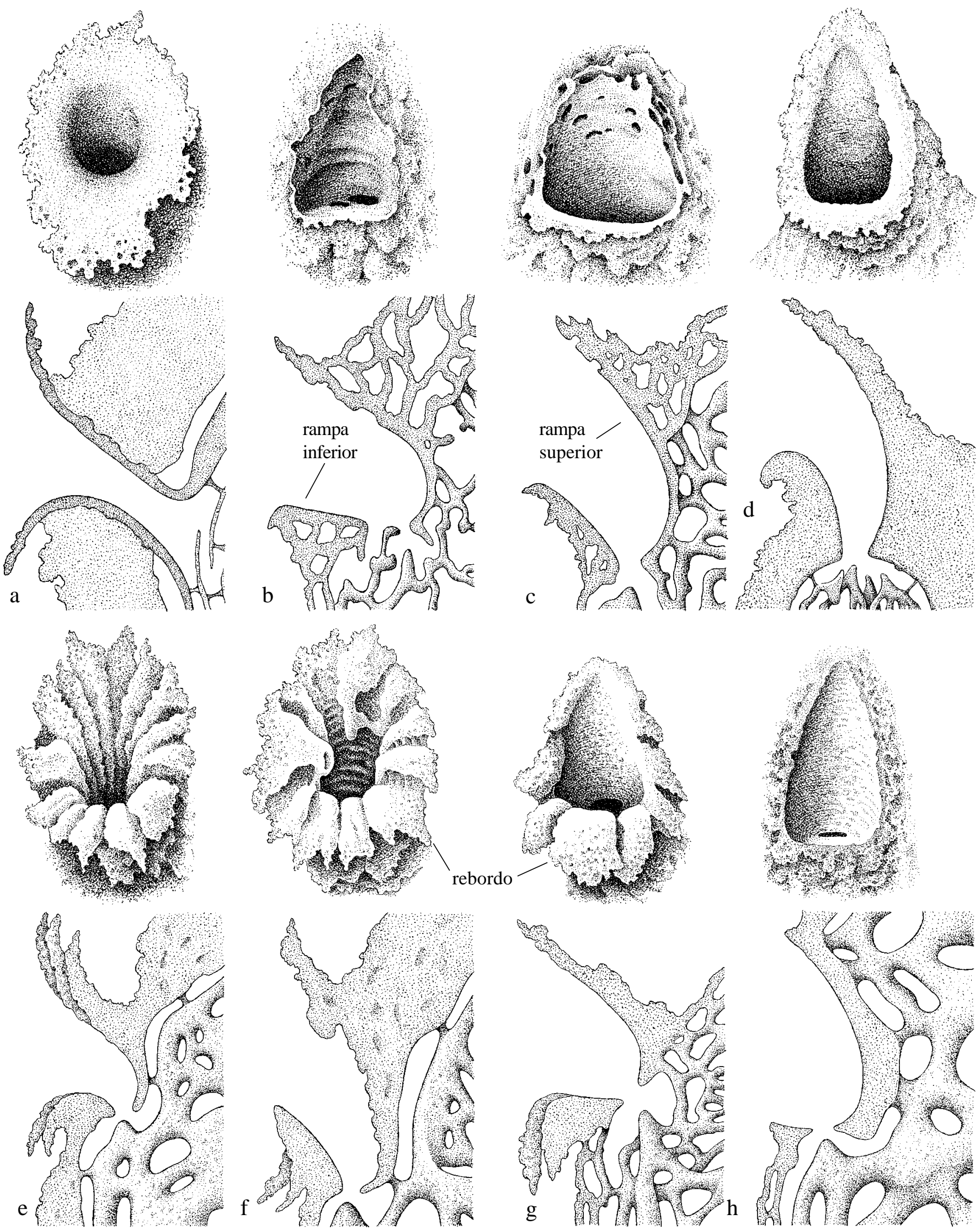

Fig. 1. Entradas de ninhos de espécies de Parapartamona e Partamona, em vista frontal e de perfil: a, Parapartamona vittigera; b, Partamona epiphytophila; c, P. helleri; d, P. testacea; e, P. vicina; f, P. mourei; g, P. ailyae; h, P. combinata. 

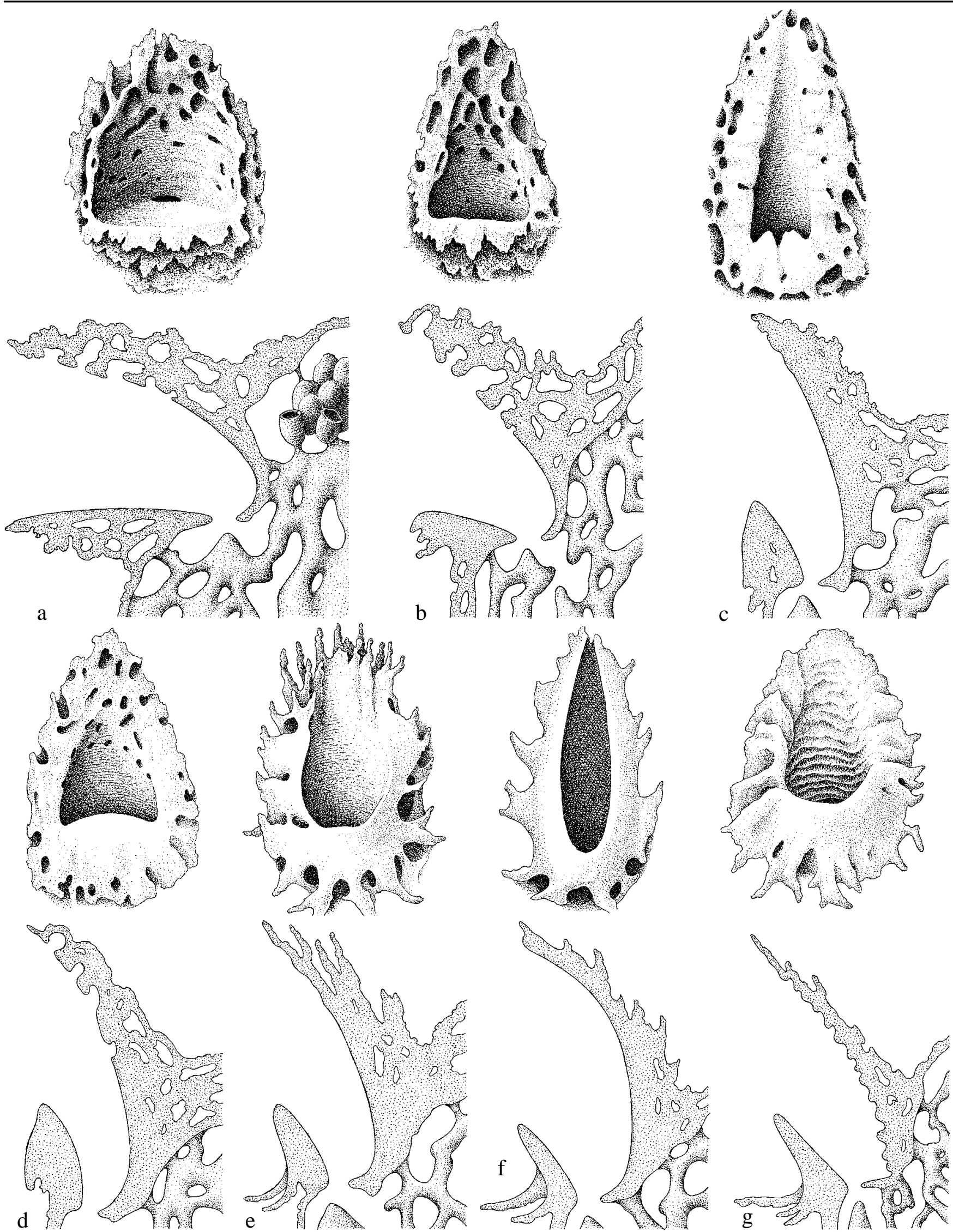

Fig. 2. Entradas de ninhos de espécies de Partamona, em vista frontal e de perfil: a, b, Partamona ferreirai; c, P. chapadicola; d, P. nhambiquara; e, P. gregaria; f, P.batesi; g, P. pearsoni. 


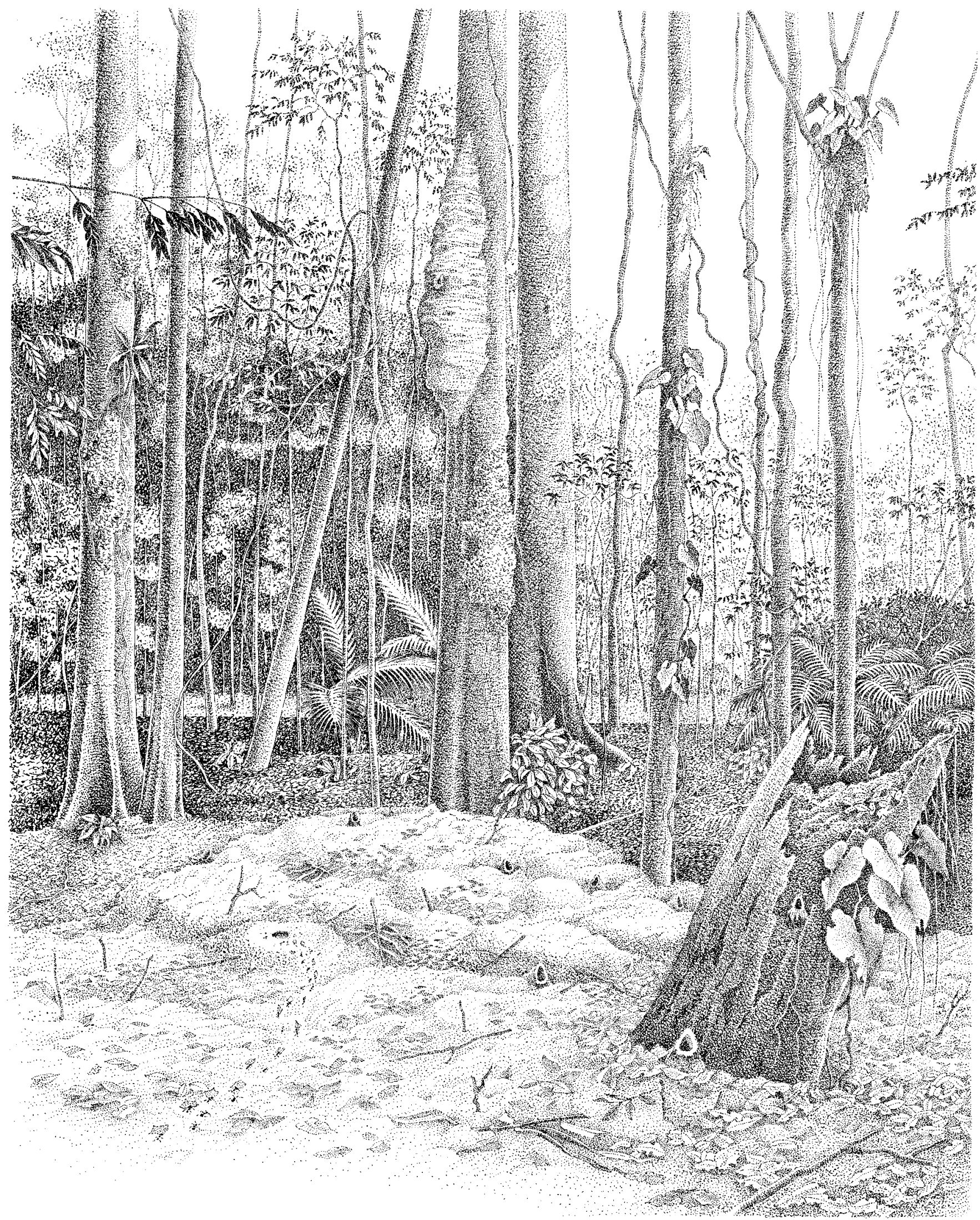

Fig. 3. Paisagem amazônica - região de São Paulo de Olivença, AM, Brasil, mostrando alguns tipos de substratos de nidificação utilizados pelas espécies de Partamona: P. testacea, ninhos subterrâneos, em formigueiro ativo de Atta sp. (sete entradas, agregação 71 - 81c); P. ailyae, em termiteiro em tronco podre, à direita; P. vicina, em termiteiro arborícola, Nasutitermes cf. similis, no alto, centro (ninho 84c); P. epiphytophila, sob raízes de epífita, no alto, à direita (ninho 86c). 


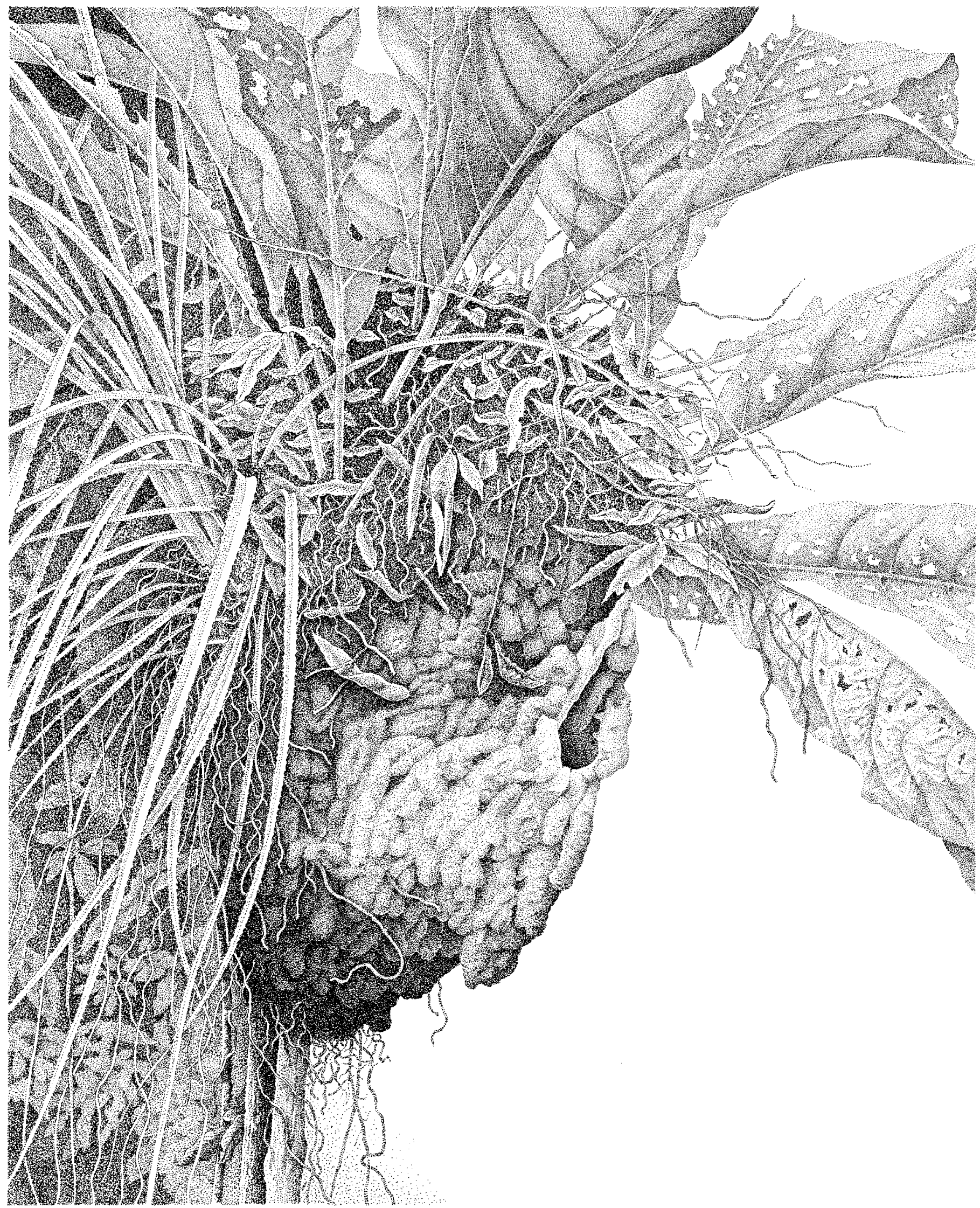

Fig. 4. Partamona epiphytophila, detalhe do ninho sob raízes de epífitas, Forte da Graça, rio Juruá, AM, Brasil (ninho 558c, diâmetro vertical do ninho, $40,0 \mathrm{~cm}$ ). 

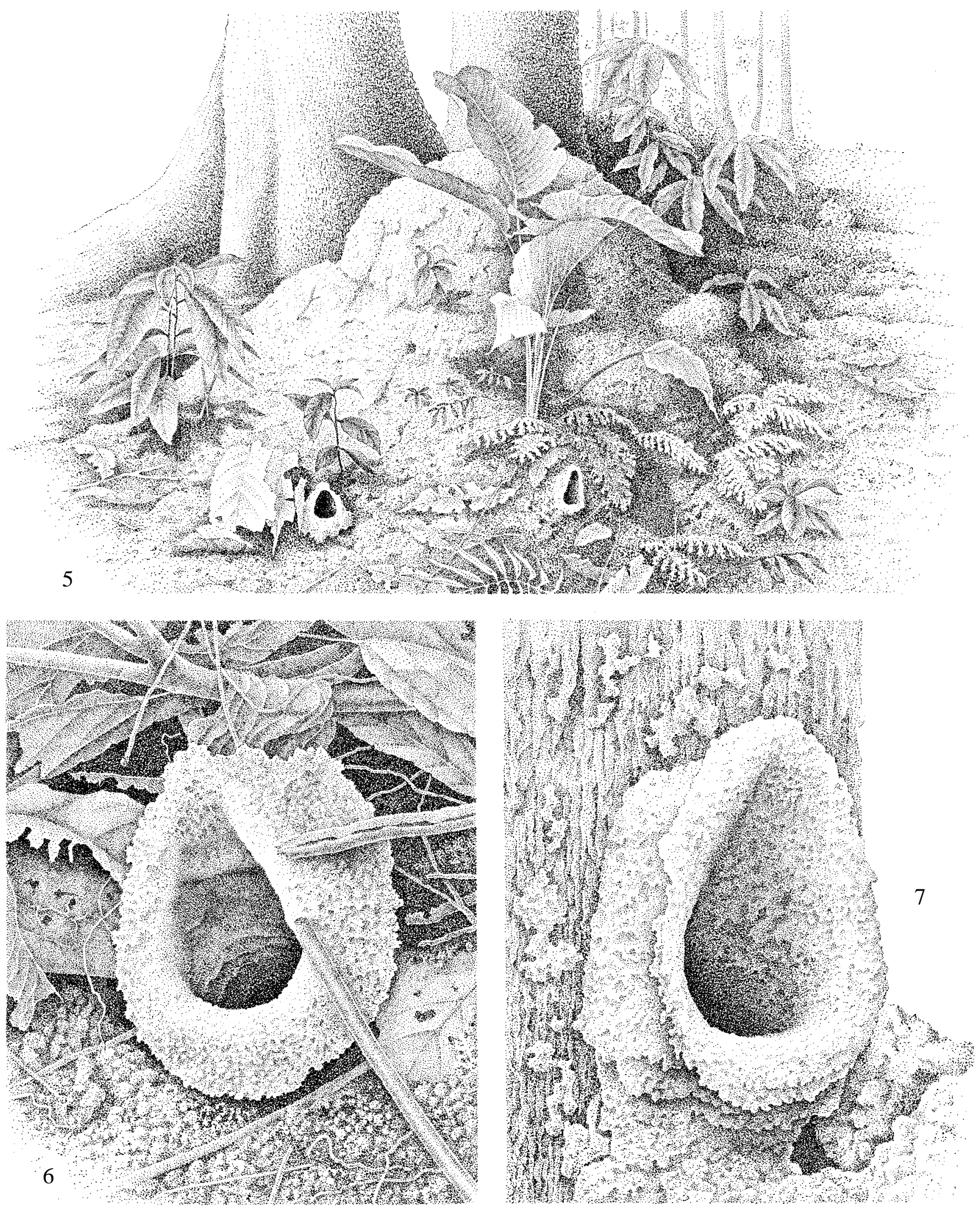

Figs. 5-7. Partamona testacea. 5, ninhos subterrâneos, em termiteiro ativo, Syntermes sp., Bacururu, rio Juruá, AM, Brasil (ninhos 550-551c); 6, detalhe da entrada, Benjamin Constant, AM (ninho 58c); 7, entrada, ninho sob raízes de árvore, Vendaval, AM. Altura externa das entradas, 6,0-7,0 $\mathrm{cm}$. 


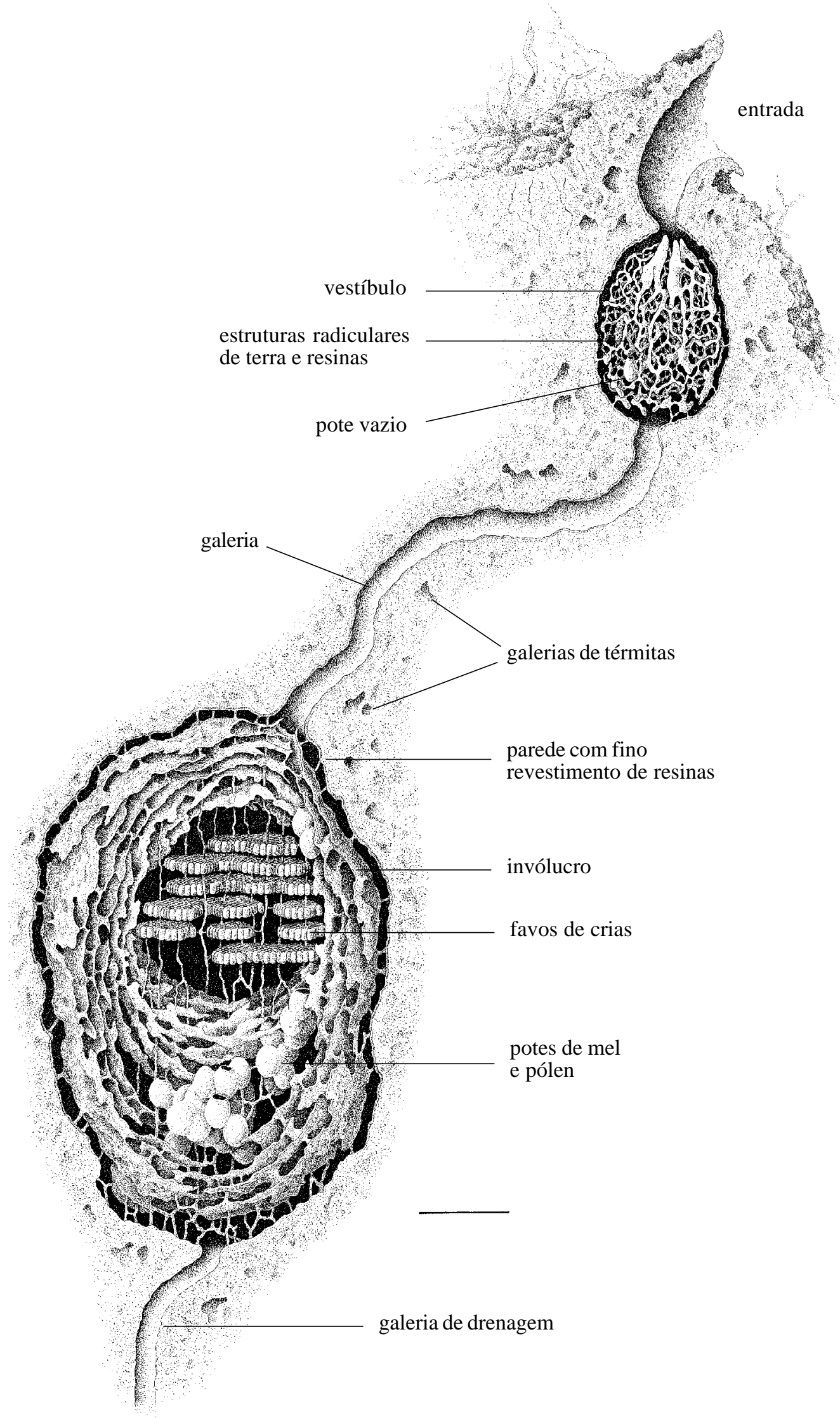

Fig. 8. Partamona testacea, ninho subterrâneo em termiteiro ativo, Syntermes sp., Bacururu, rio Juruá, AM, Brasil (ninho $544 \mathrm{c}$ ). Escala $=5$ cm. 

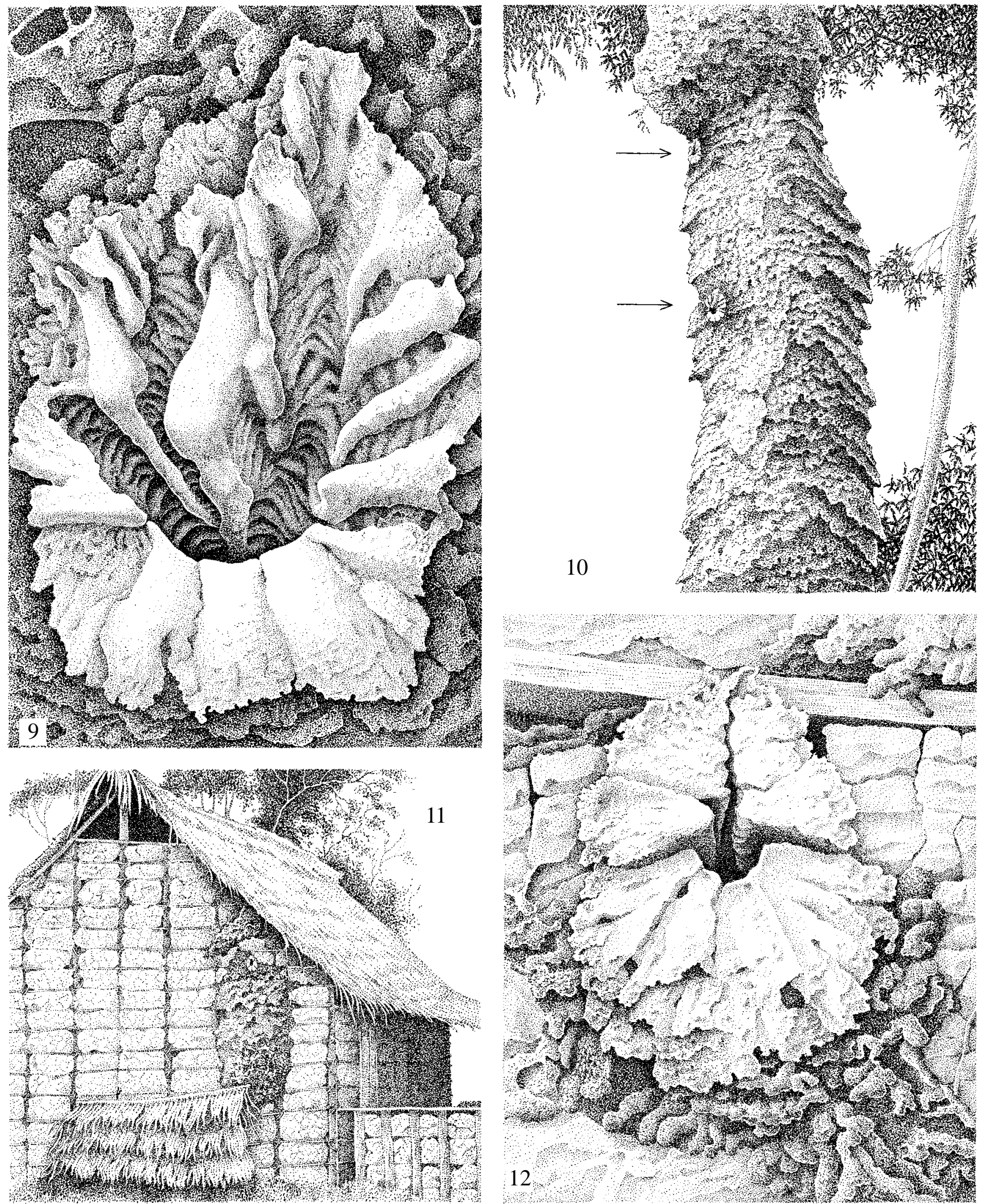

Figs. 9-12. Partamona mourei. 9-10, detalhe da estrutura de entrada e do substrato, termiteiro arborícola ativo, Amitermes sp., lago Carimun, rio Trombetas, PA, Brasil (ninhos 188c e 189c, altura da entrada, 22,0 cm); 11-12, substrato, termiteiro em parede de casa, e detalhe da entrada, Livramento, rio Negro, AM, Brasil (ninhos 241c e 242c, altura da entrada, 15,0 cm). 


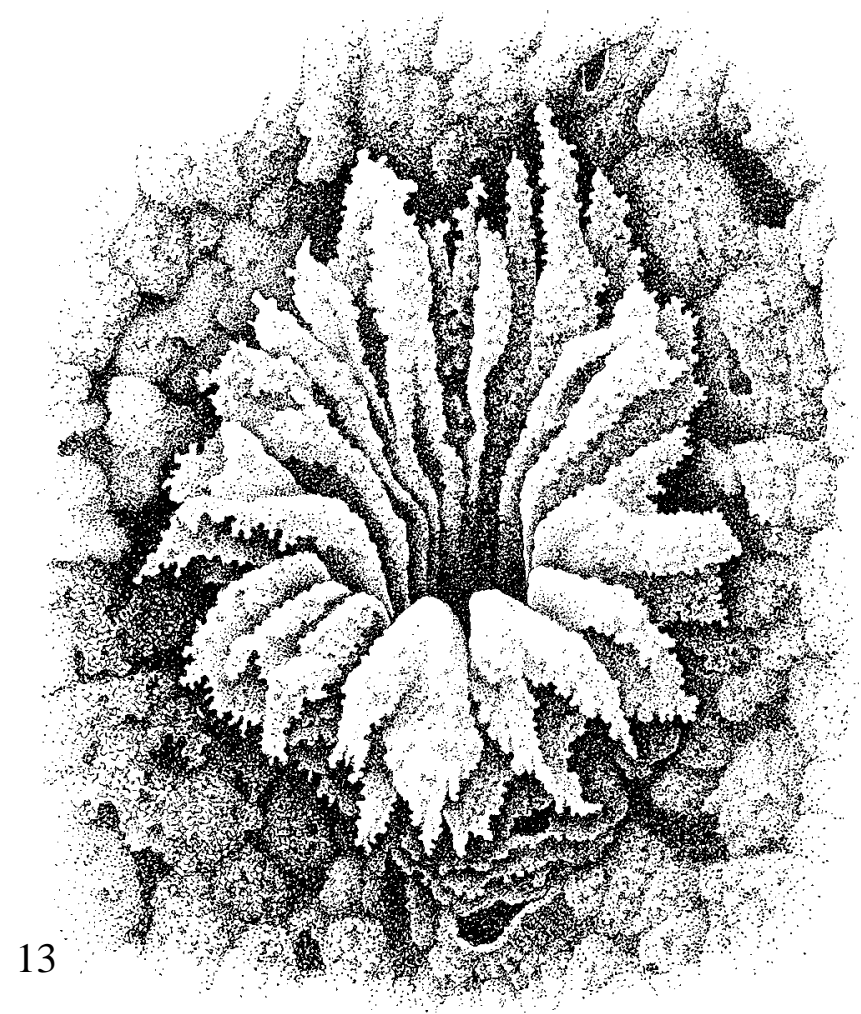

14
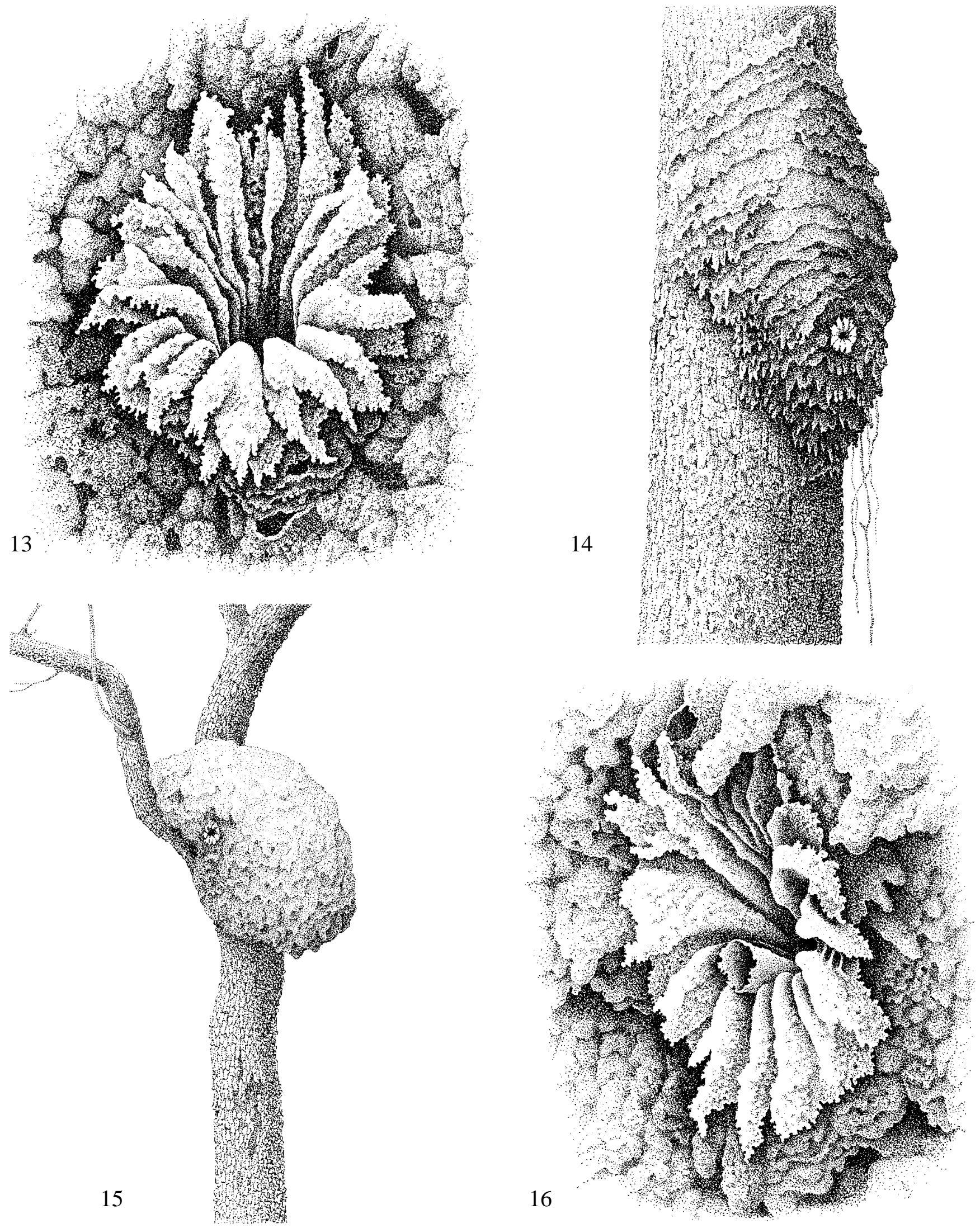

Figs. 13-16. Partamona vicina. 13, detalhe da estrutura de entrada, Sta. Maria, Itaituba, PA, Brasil (ninho 134c, altura da entrada, 12,0 cm); 14, ninho em termiteiro arborícola ativo, Curicuriari, AM, Brasil (ninho 221c); 15, ninho em termiteiro arborícola ativo, Constrictotermes cyphergaster, Aragarças, GO, Brasil (ninho 21c, termiteiro com 54,0 cm de altura); 16, detalhe da entrada; ninho sob ataque de Lestrimelitta sp., com pequeno tubo do hóspede dentro da entrada de $P$. vicina, rio Ipixuna, AM (ninho 337c, altura da entrada de $P$. vicina, 12,0 cm). 


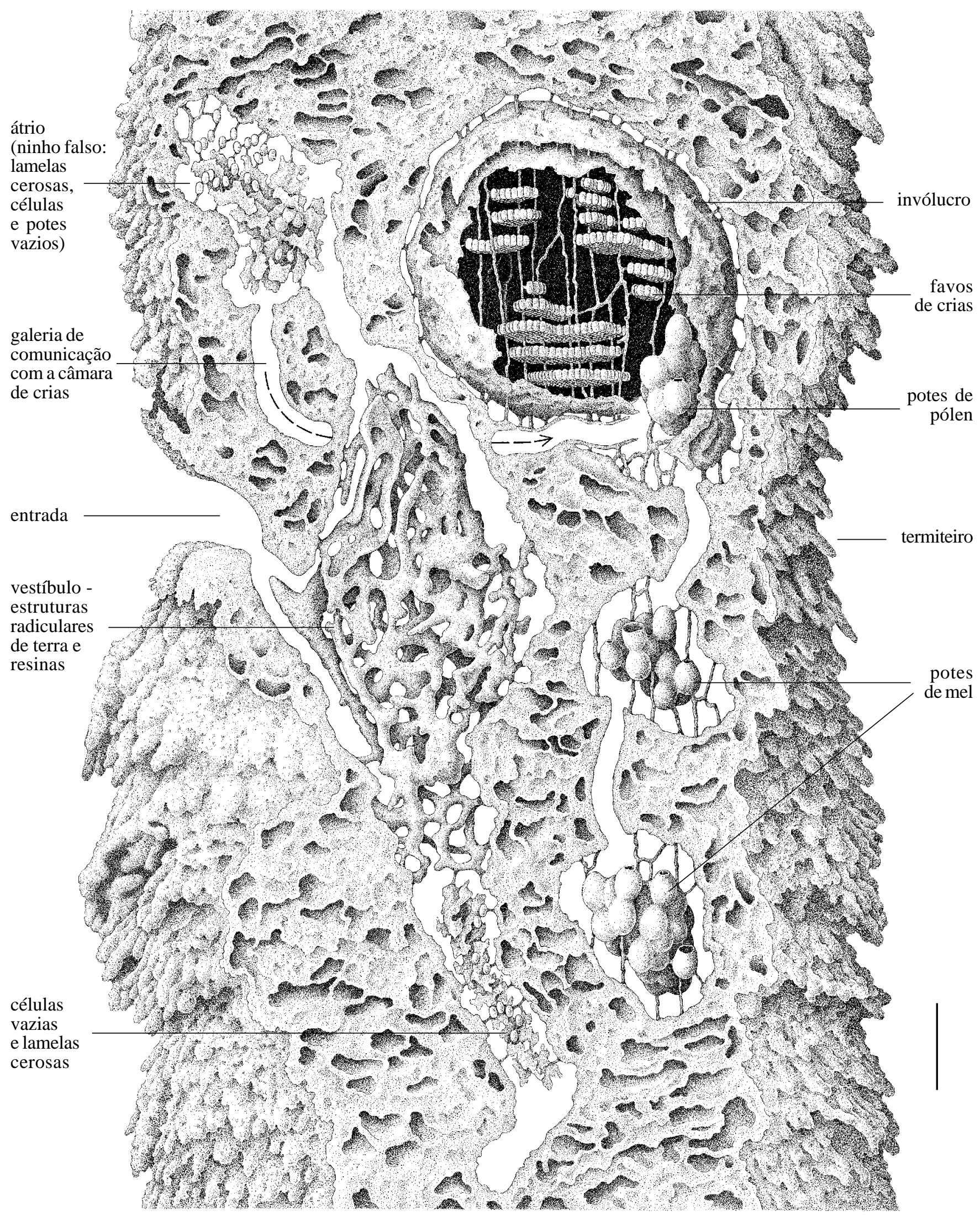

Fig. 17. Partamona vicina, ninho em termiteiro arborícola ativo, Amitermes excellens, Muçum, rio Tapajós, PA, Brasil (ninho $153 \mathrm{c})$. Escala $=5 \mathrm{~cm}$. 


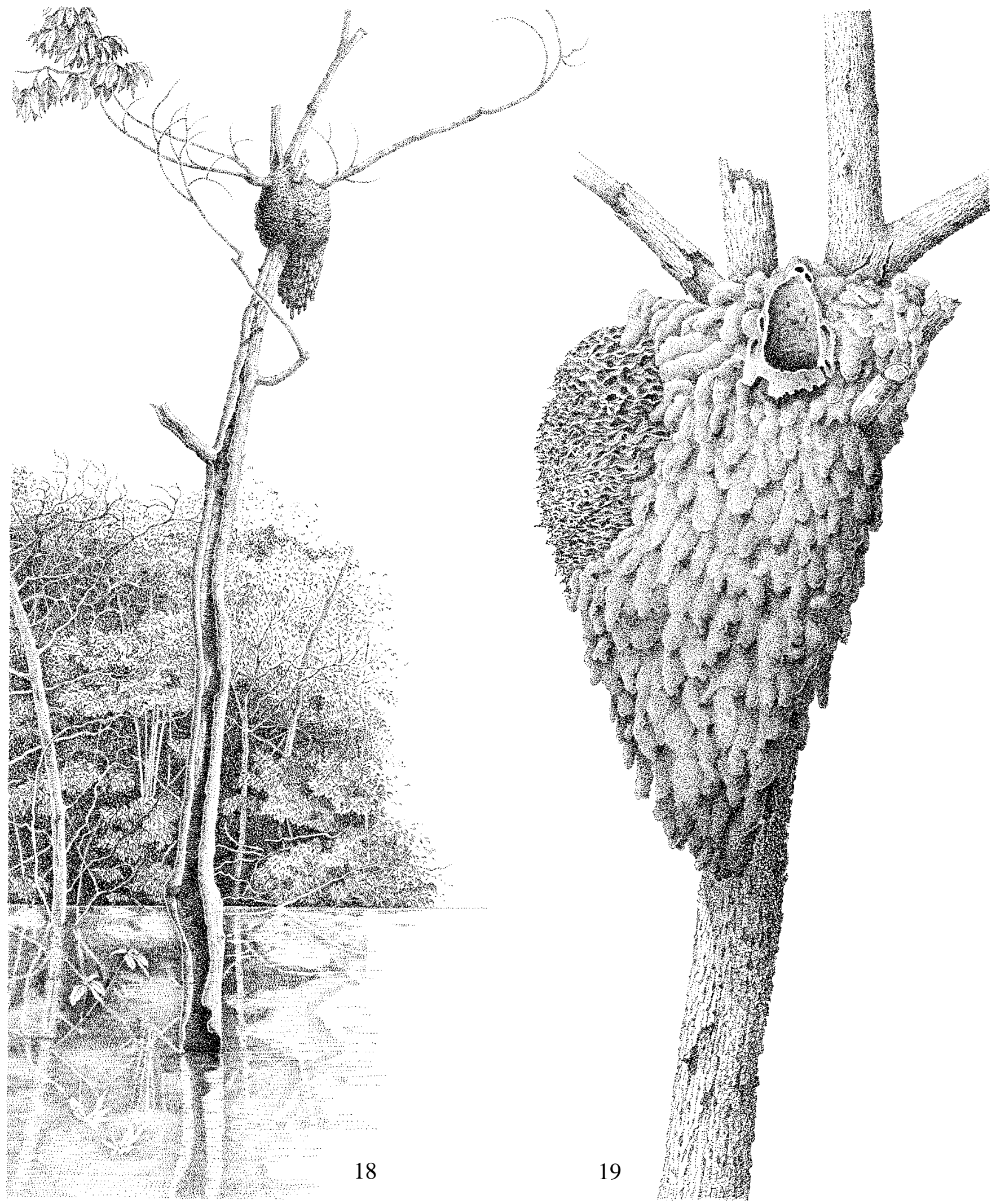

Figs. 18-19. Partamona auripennis, ninho em termiteiro arborícola abandonado, Tauari, Tapajós, PA, Brasil (ninho 168c). 18, vista geral, igapó; 19, detalhe do ninho; todas as estruturas tubulares abaixo e nos lados da entrada foram construídas pelas abelhas (tamanho do ninho, externamente, $50,0 \times 34,0 \mathrm{~cm})$. 


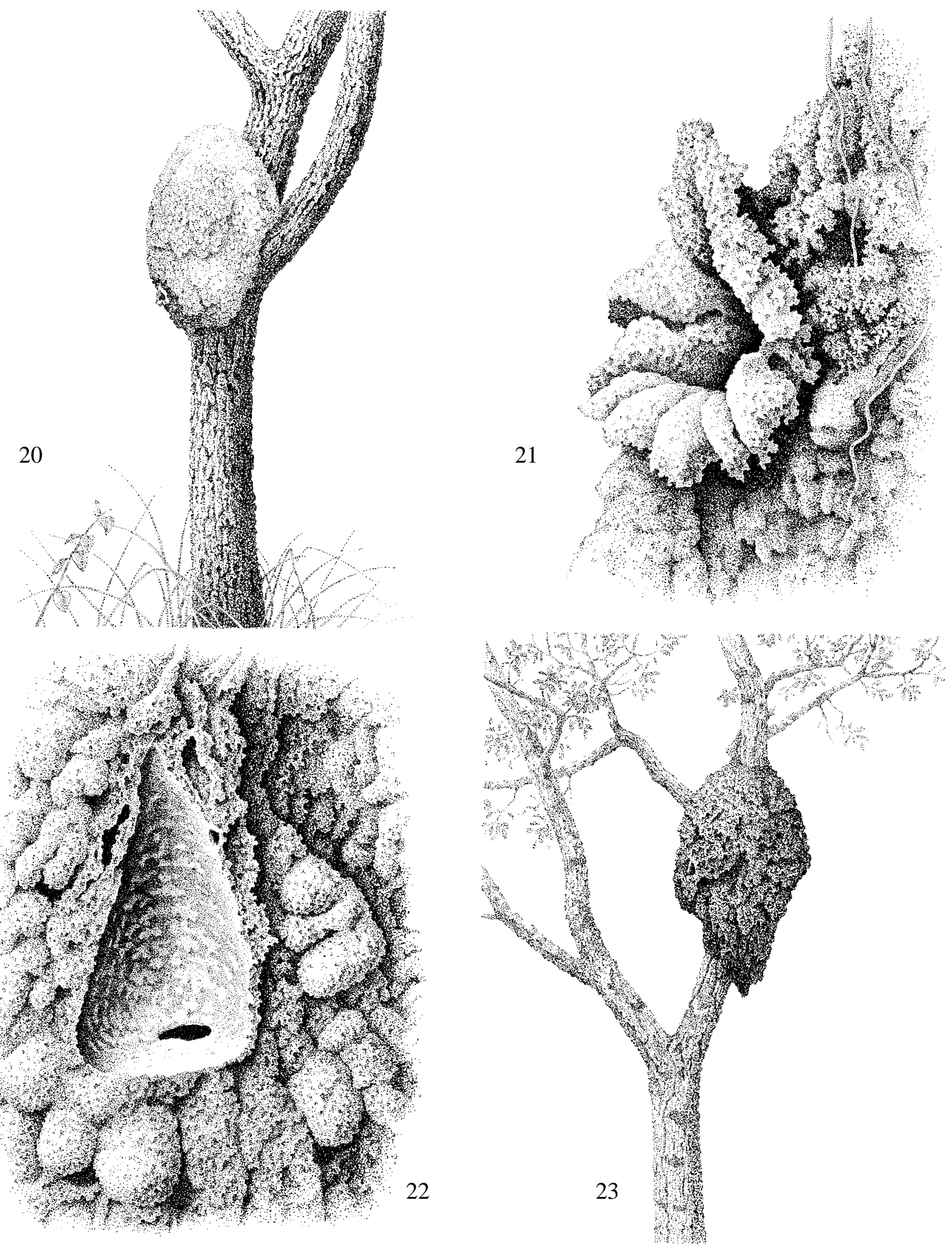

Figs. 20-23. Partamona, ninhos. 20, P. seridoensis, em termiteiro arborícola ativo, $80 \mathrm{Km}$ SW de Alto Parnaíba, MA, Brasil (ninho 502c, diâmetro vertical do termiteiro, 60,0 cm); 21, P. seridoensis, entrada do ninho, Urbano Santos, MA (ninho 300c, altura da entrada, 5,0 cm); 22. P. combinata, entrada do ninho, em termiteiro arborícola ativo, Aragarças, GO, Brasil (ninho 4c, altura da entrada, 7,0 cm); 23, P. combinata, em termiteiro arborícola ativo, Cristalina, GO. 


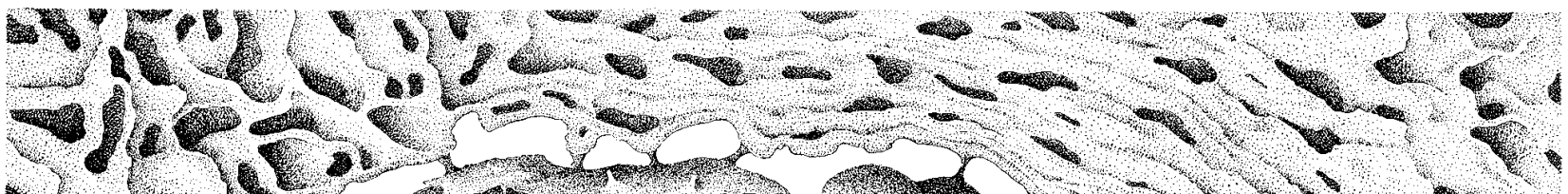

V. P.

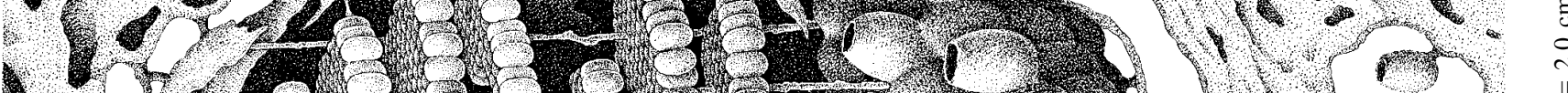

L

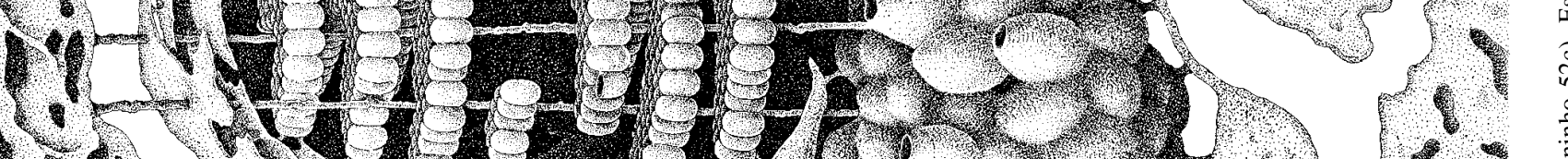

1
1

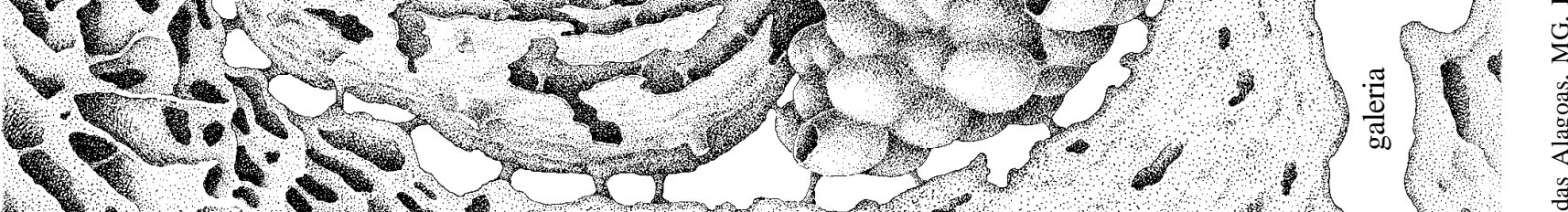

3.

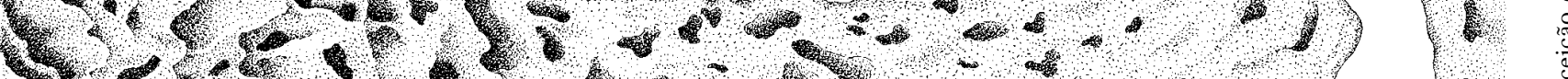

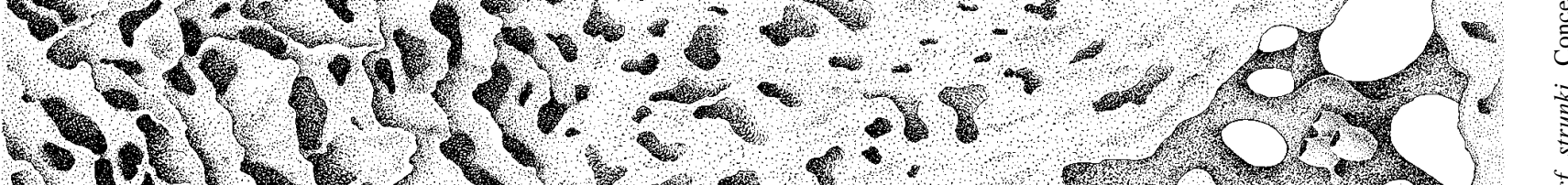

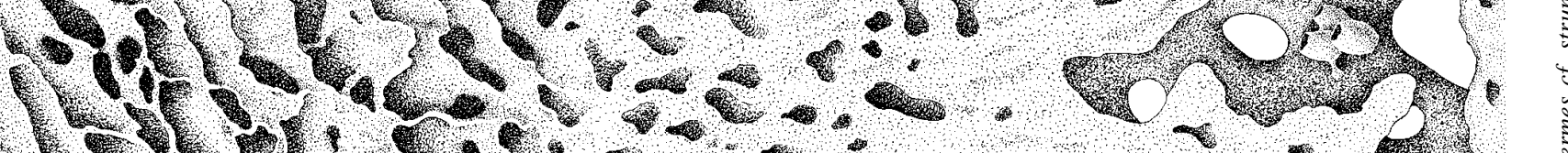

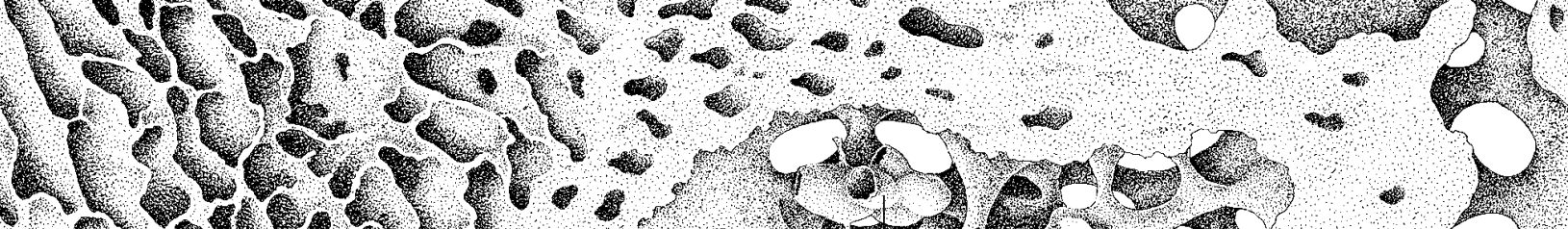

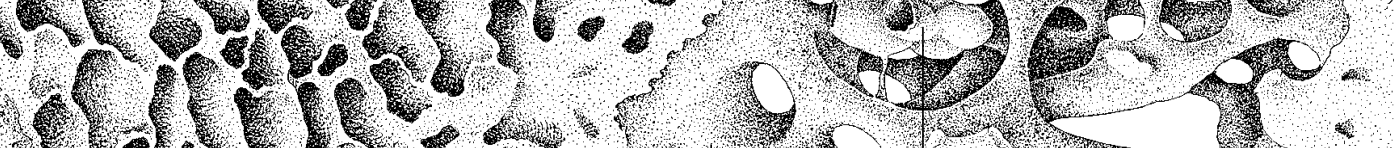

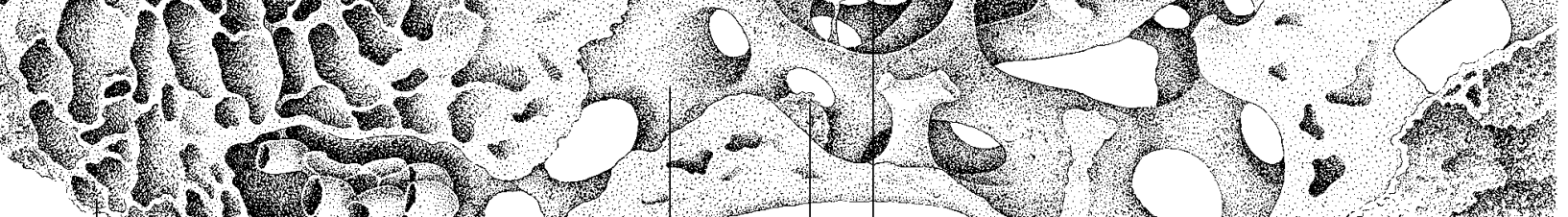

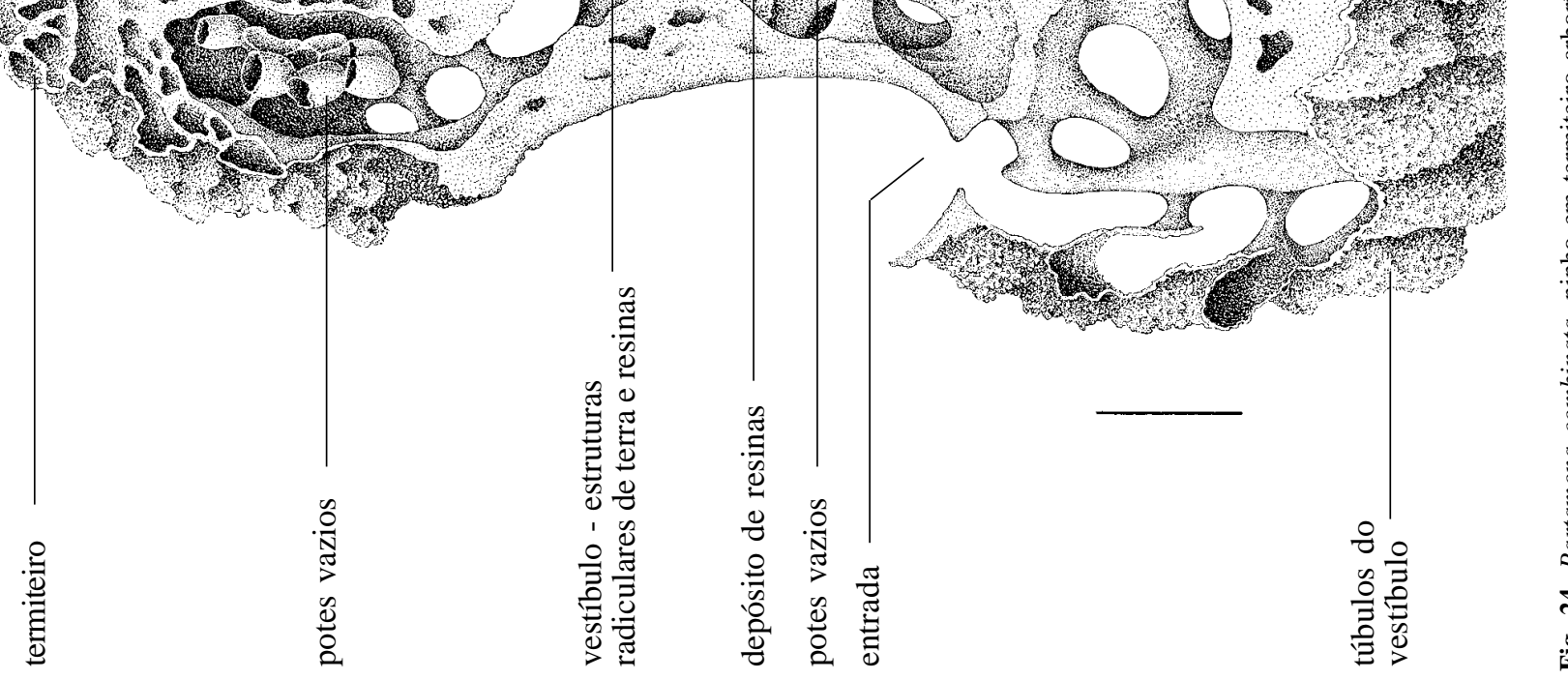




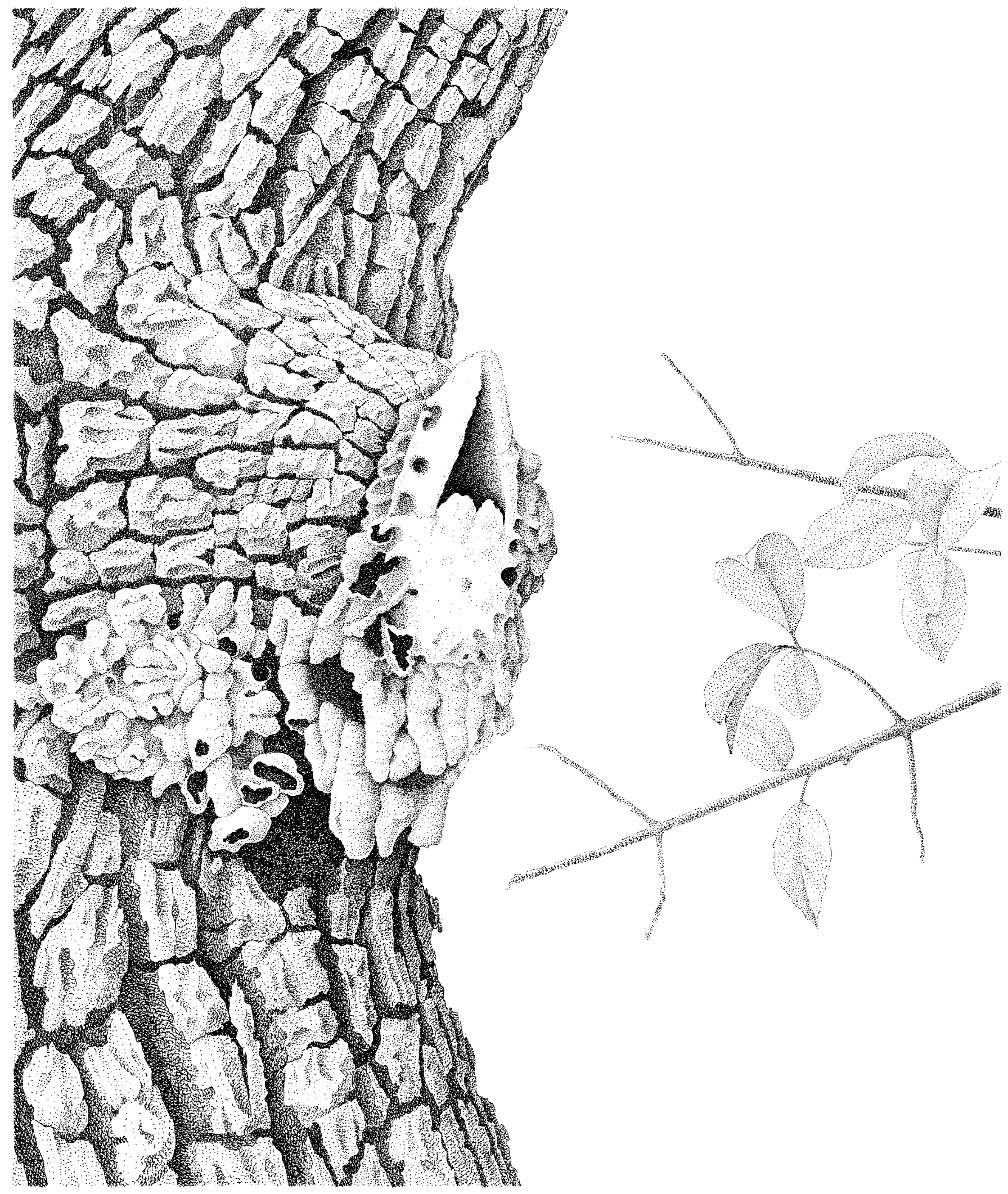

Fig. 25. Partamona chapadicola, entrada do ninho, em termiteiro ativo em oco de árvore viva, Chapadinha, MA, Brasil (ninho 665c, altura da boca de entrada, $10,0 \mathrm{~cm}$ ). 


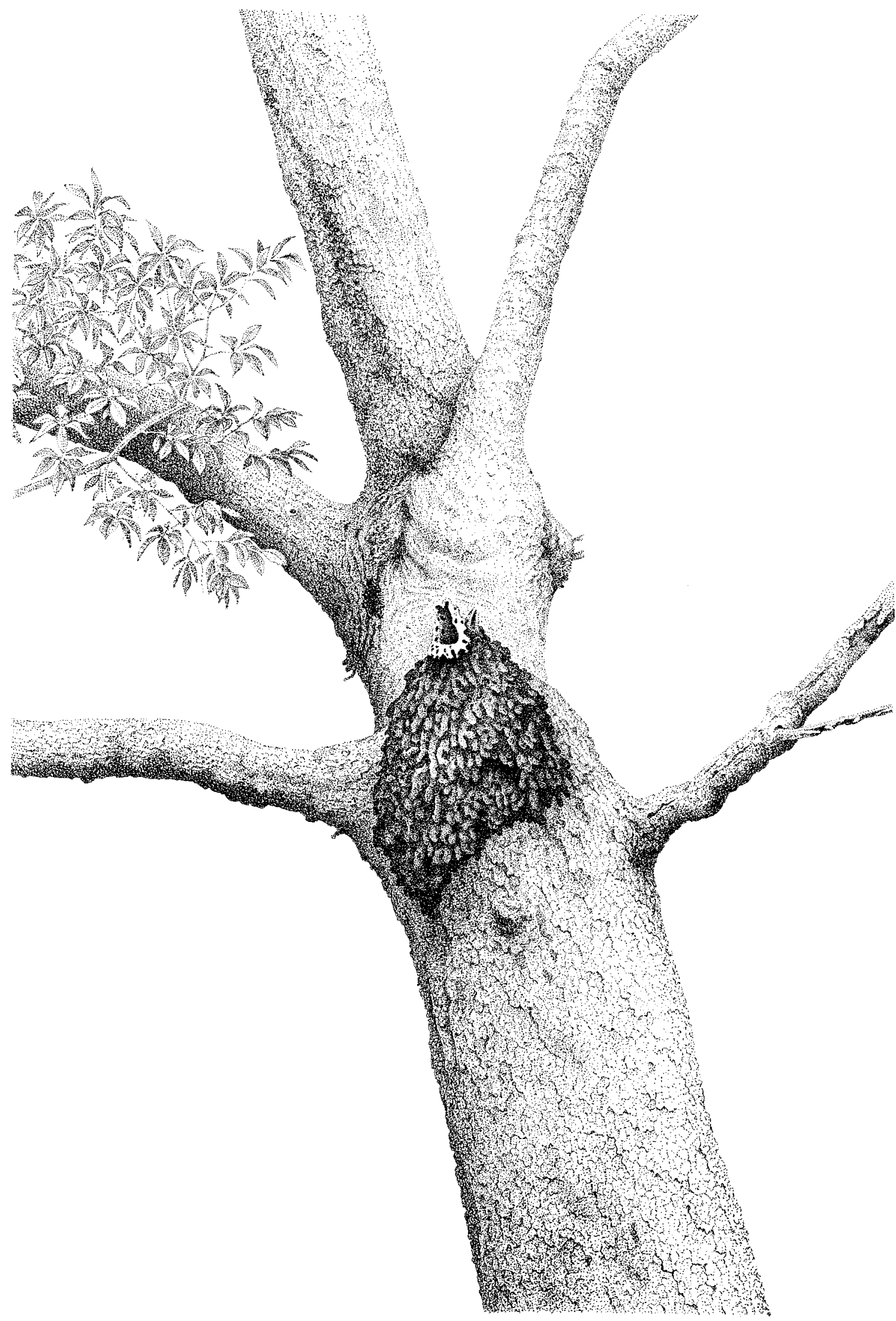

Fig. 26. Partamona nhambiquara, entrada do ninho, em termiteiro ativo em oco de árvore viva; a grande massa de estruturas tubulares (35,0 $\mathrm{cm}$ de altura), abaixo da entrada, foi construída pelas abelhas; Serra dos Pacaás Novos, Guajará Mirim, RO, Brasil (baseado em foto obtida por M. L. Oliveira em 21.I.1996). 


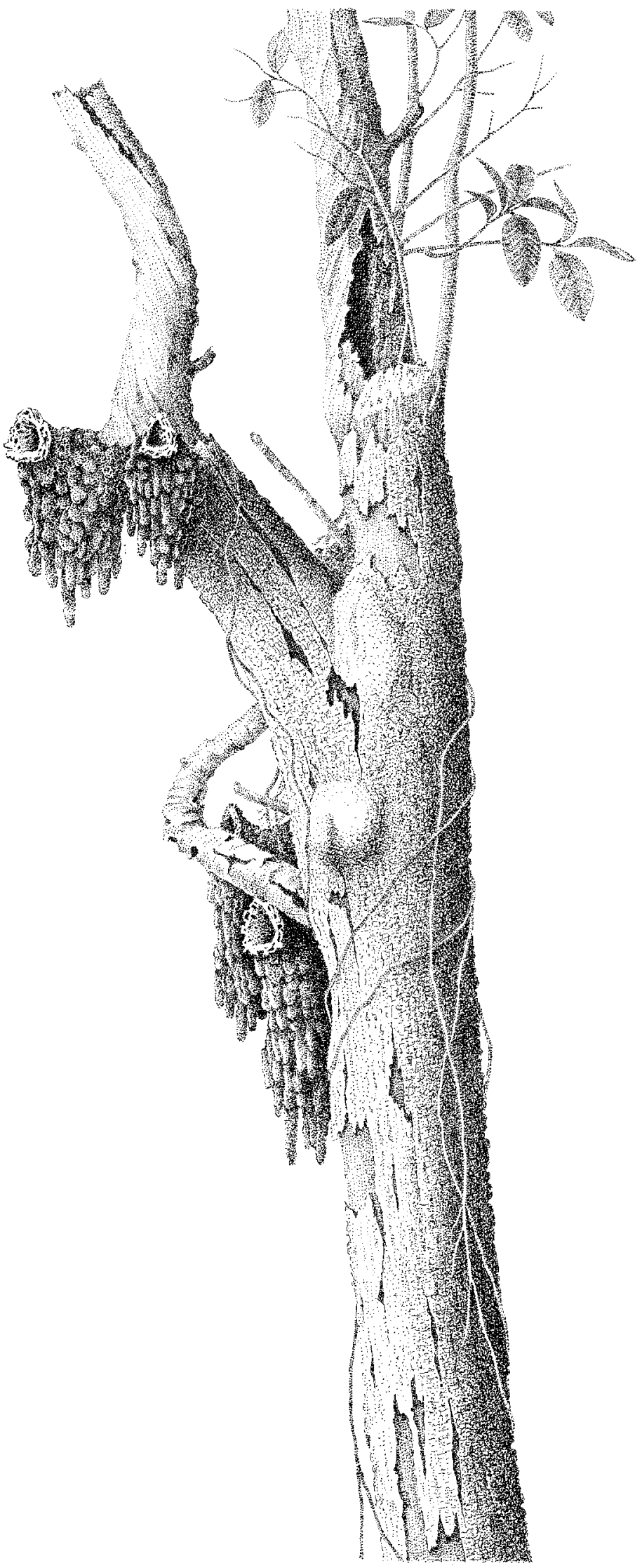

Fig. 27. Partamona ferreirai, entradas de ninhos em termiteiro ativo em oco de árvore seca, lago Água Fria, rio Trombetas, PA, Brasil (ninhos 181184c). 

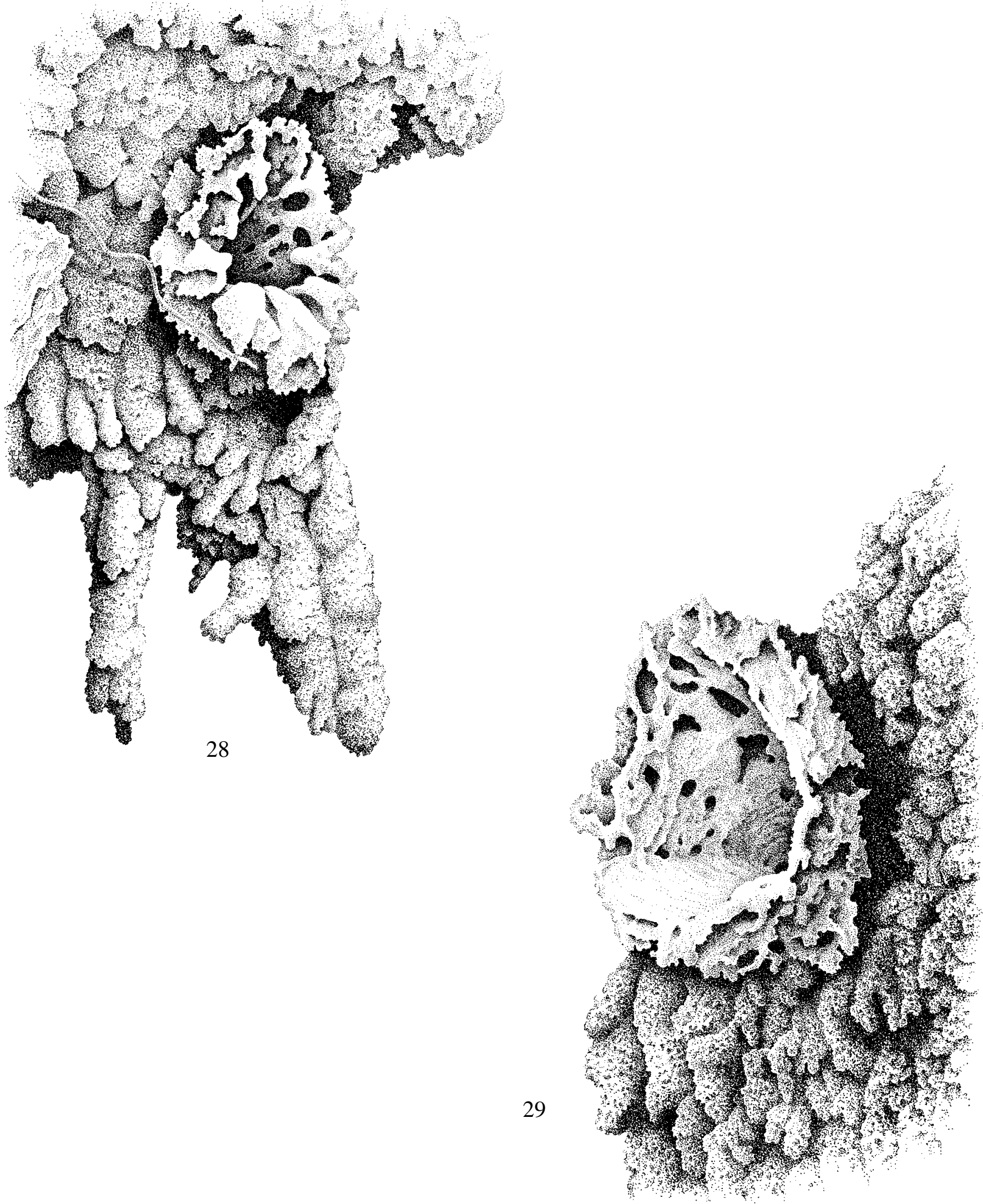

Figs. 28-29. Partamona ferreirai, detalhes da estrutura de entrada, ninhos em termiteiros ativos em oco de árvore seca. 28, foz do rio Daraã, rio Negro, AM, Brasil, Termes cf. hispaniolae (ninho 252c, altura da entrada, 9,0 cm); 29, lago Água Fria, rio Trombetas, PA, Brasil (ninho 181c, altura da entrada, $13,0 \mathrm{~cm})$. 


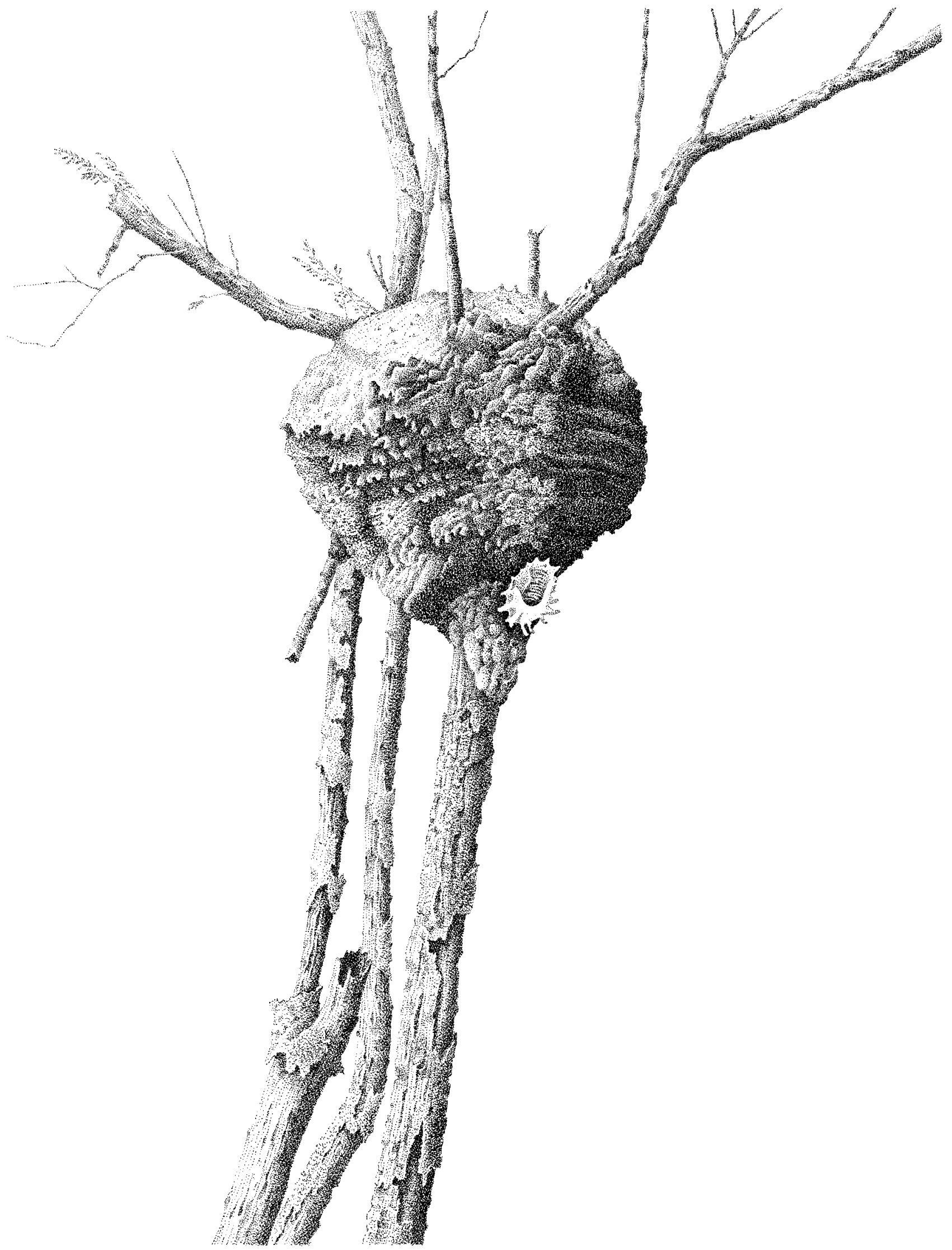

Fig. 30. Partamona pearsoni, ninho em termiteiro arborícola ativo, Nasutitermes cf. peruanus (diâmetro do termiteiro, 40,0 cm), foz do rio Daraã, rio Negro, AM, Brasil (ninho 249c). 


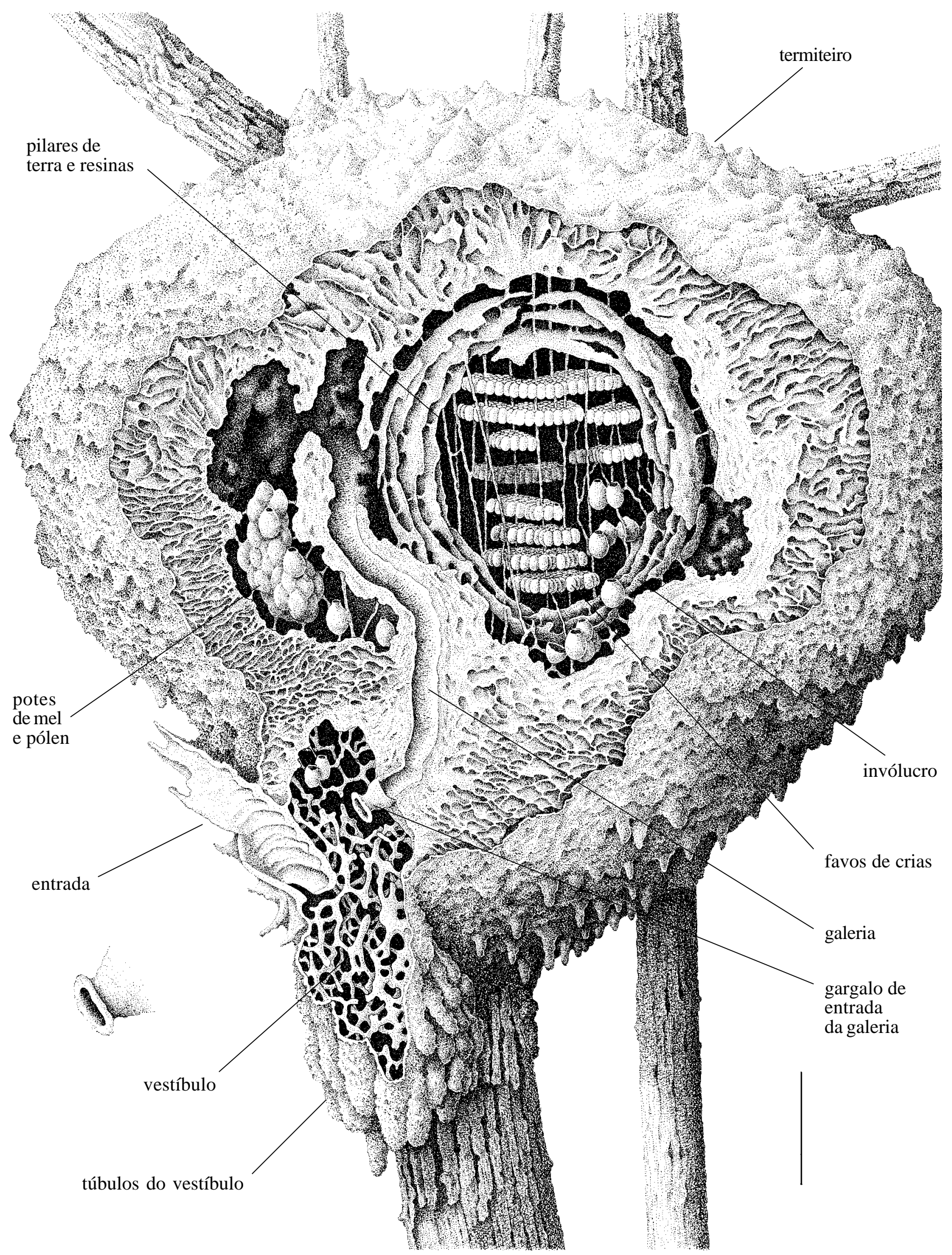

Fig. 31. Partamona pearsoni, detalhe do ninho em corte longitudinal, em termiteiro arborícola ativo, Nasutitermes cf. peruanus, foz do rio Daraã, rio Negro, AM, Brasil (ninho 249c, diâmetro do termiteiro, 40,0 cm). À esquerda, embaixo, detalhe do gargalo de entrada da galeria de comunicação com a câmara de crias. Escala $=5,0 \mathrm{~cm}$. 


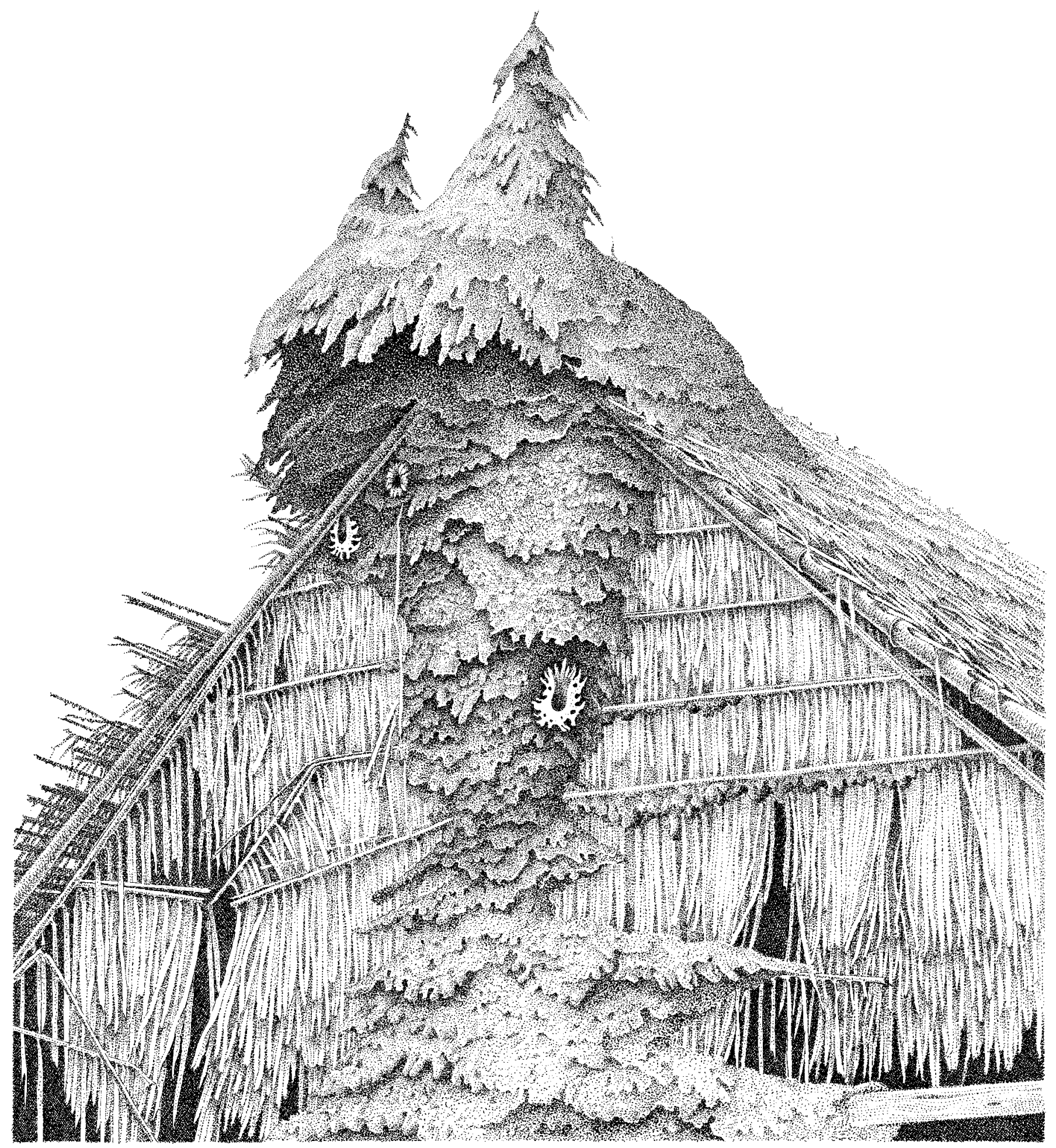

Fig. 32. Partamona gregaria, ninhos em termiteiro ativo (as duas entradas mais abaixo); em cima, entrada de um ninho de Partamona vicina, Tauari, rio Tapajós, PA, Brasil. 


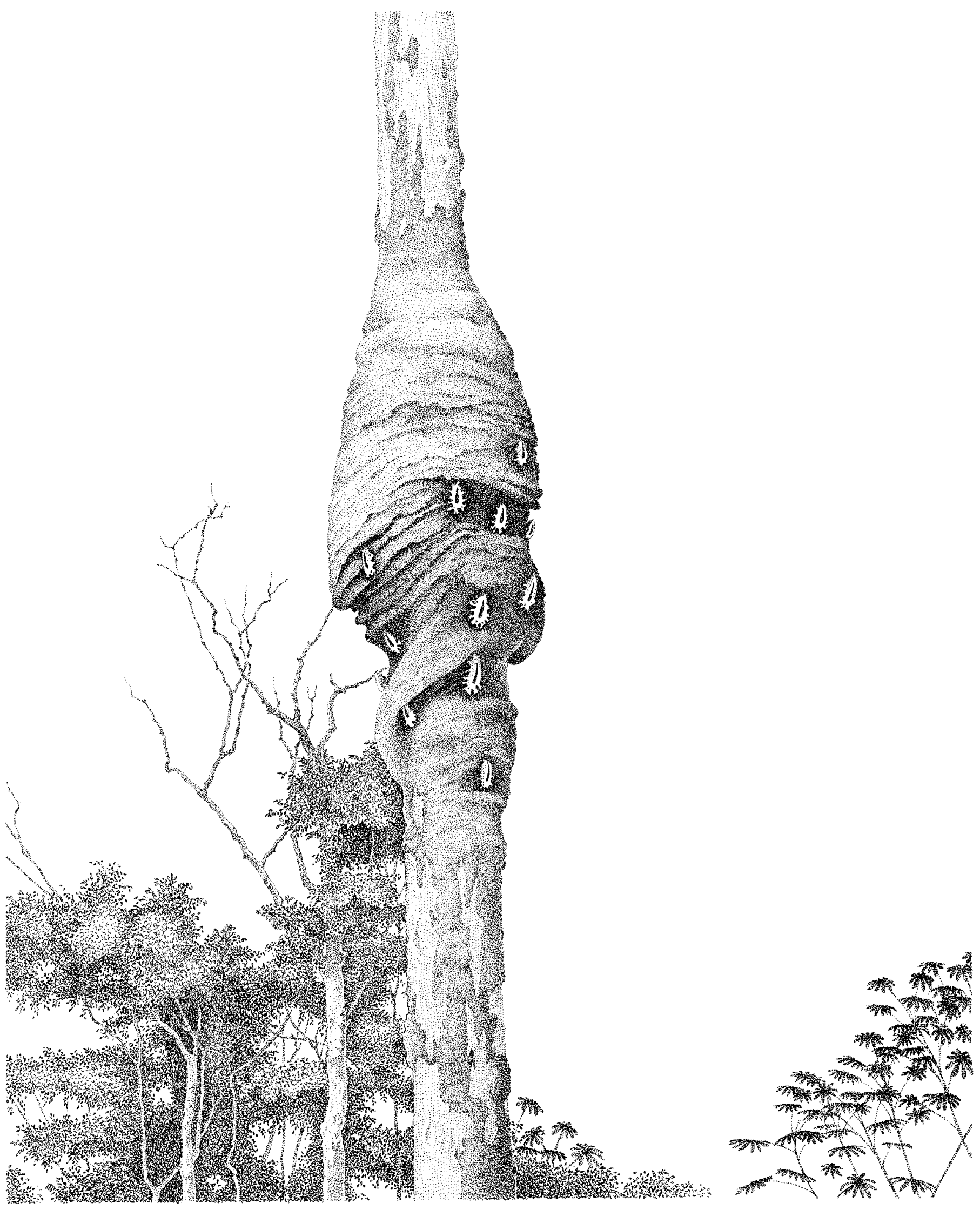

Fig. 33. Partamona batesi, agregação de ninhos (570c) em termiteiro arborícola ativo, Nasutitermes acangussu, em roçado, Forte da Graça, rio Juruá, AM, Brasil (o termiteiro com cerca de 2,00 m de altura). 

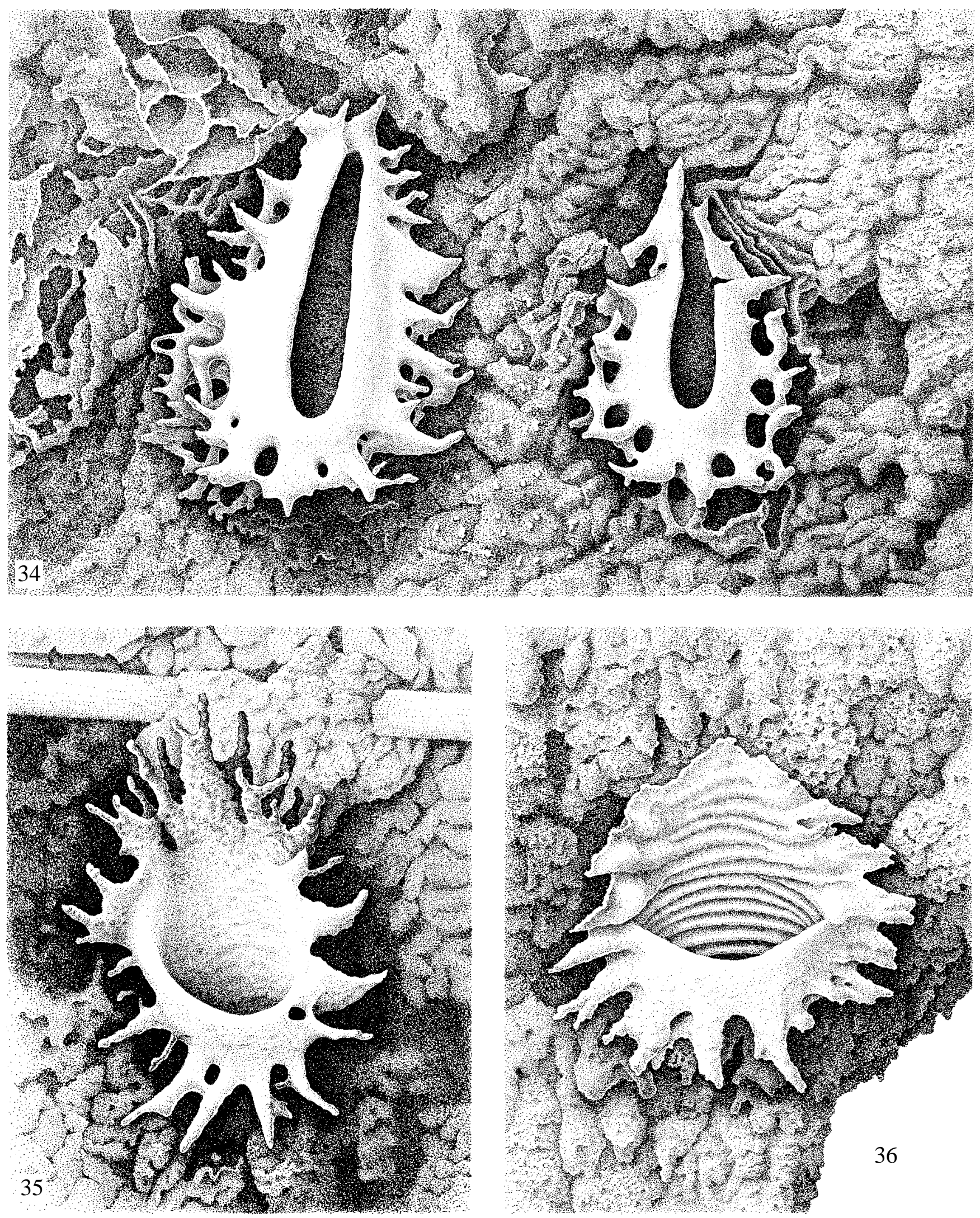

Figs. 34-36. Partamona, estruturas de entrada de ninhos. 34, P. batesi, rio Ipixuna, AM, Brasil (ninho 330c, altura externa da entrada maior, 12,0 cm); 35, P. gregaria, São Luís do Tapajós, PA, Brasil (ninho 117c, altura externa, 15,0 cm). 36. P. pearsoni, foz do rio Marié, AM (ninho 245c, altura externa, $10,0 \mathrm{~cm})$. 

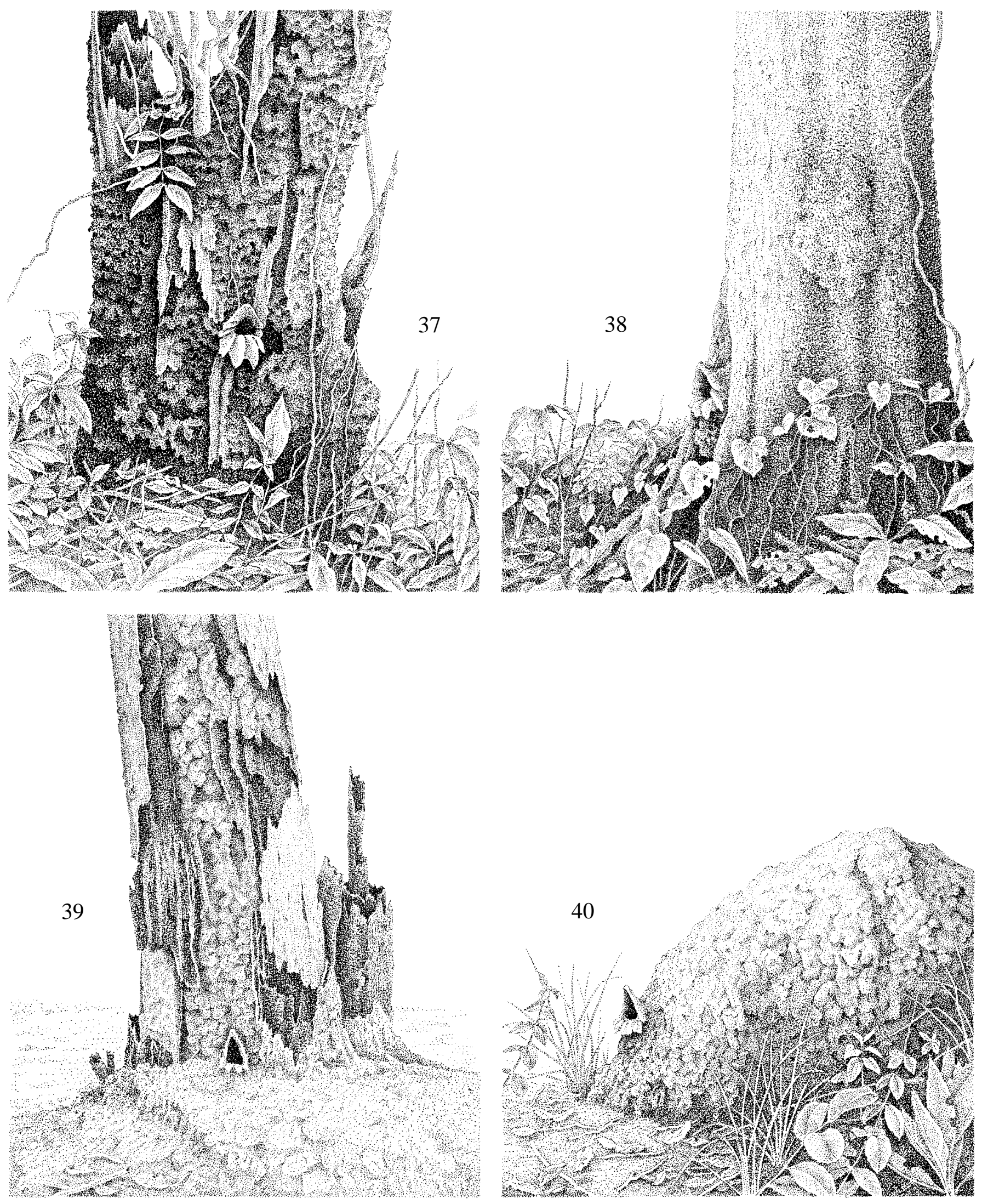

Figs. 37-40. Partamona ailyae, detalhes dos substratos preferidos. 37, termiteiro em tronco podre, Tauari, rio Tapajós, PA, Brasil (ninho 163c); 38, termiteiro no interior de tronco de castanheira viva, lago Uará, rio Solimões, AM, Brasil (ninho 576c); 39, termiteiro subterrâneo sob tronco seco, Brejo da Conceição, Bom Jesus, PI, Brasil (ninho 666c); 40, termiteiro epígeo, Aragarças, GO, Brasil (ninho 2c). 

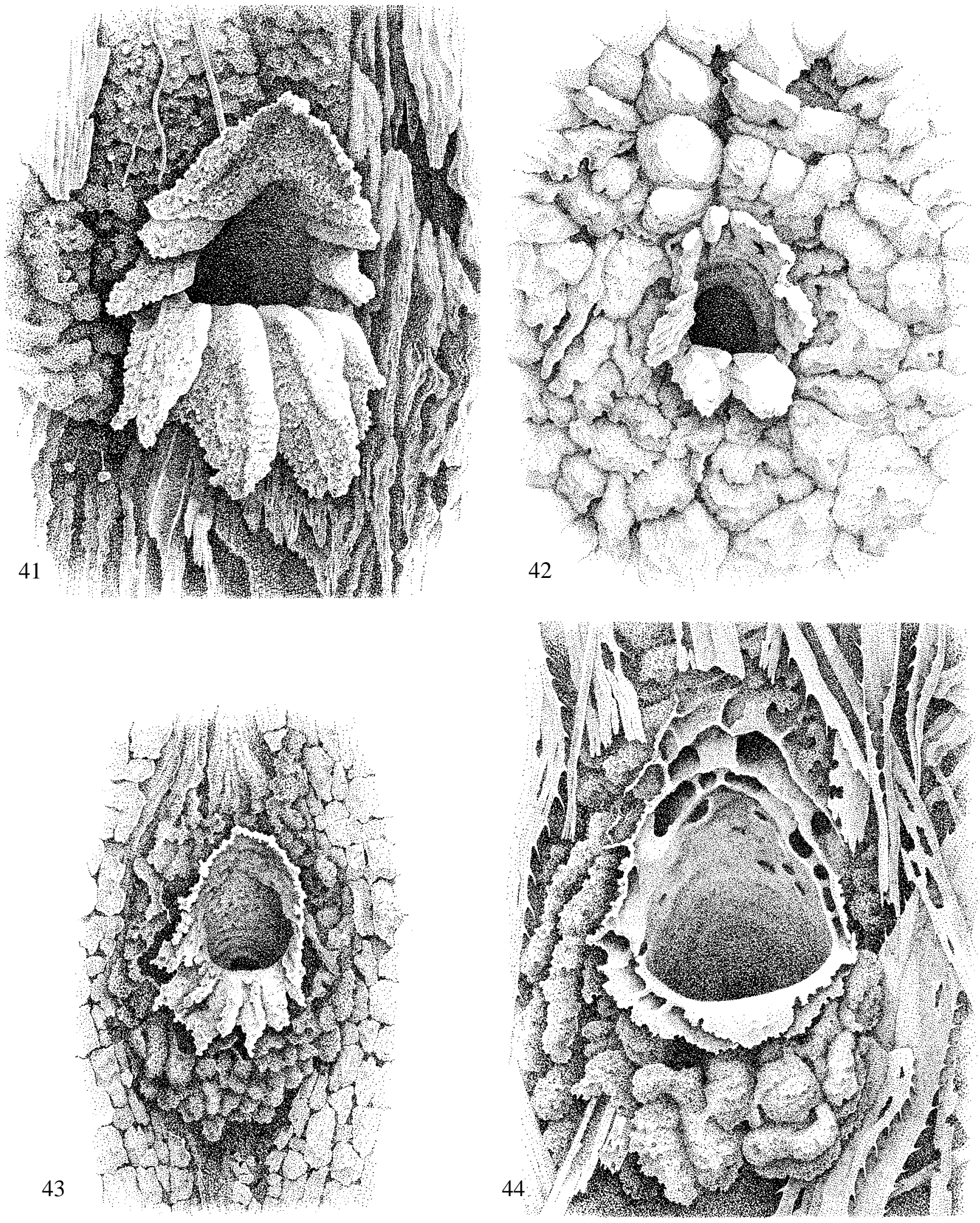

Figs. 41-44. Partamona, entradas de ninhos. 41, P. ailyae, em termiteiro em tronco seco, Tauari, rio Tapajós, PA, Brasil (ninho 163c, altura externa, 8,0 cm); 42, P. mulata, em termiteiro epígeo, Cuiabá, MT, Brasil (altura, 4,0 cm); 43, P. criptica, em termiteiro em tronco de árvore, Caeté, MG, Brasil (altura, 4,0 cm); 44, P. helleri, ninho sob epífitas, Ribeirão Preto, SP, Brasil (altura, 7,0 cm). 


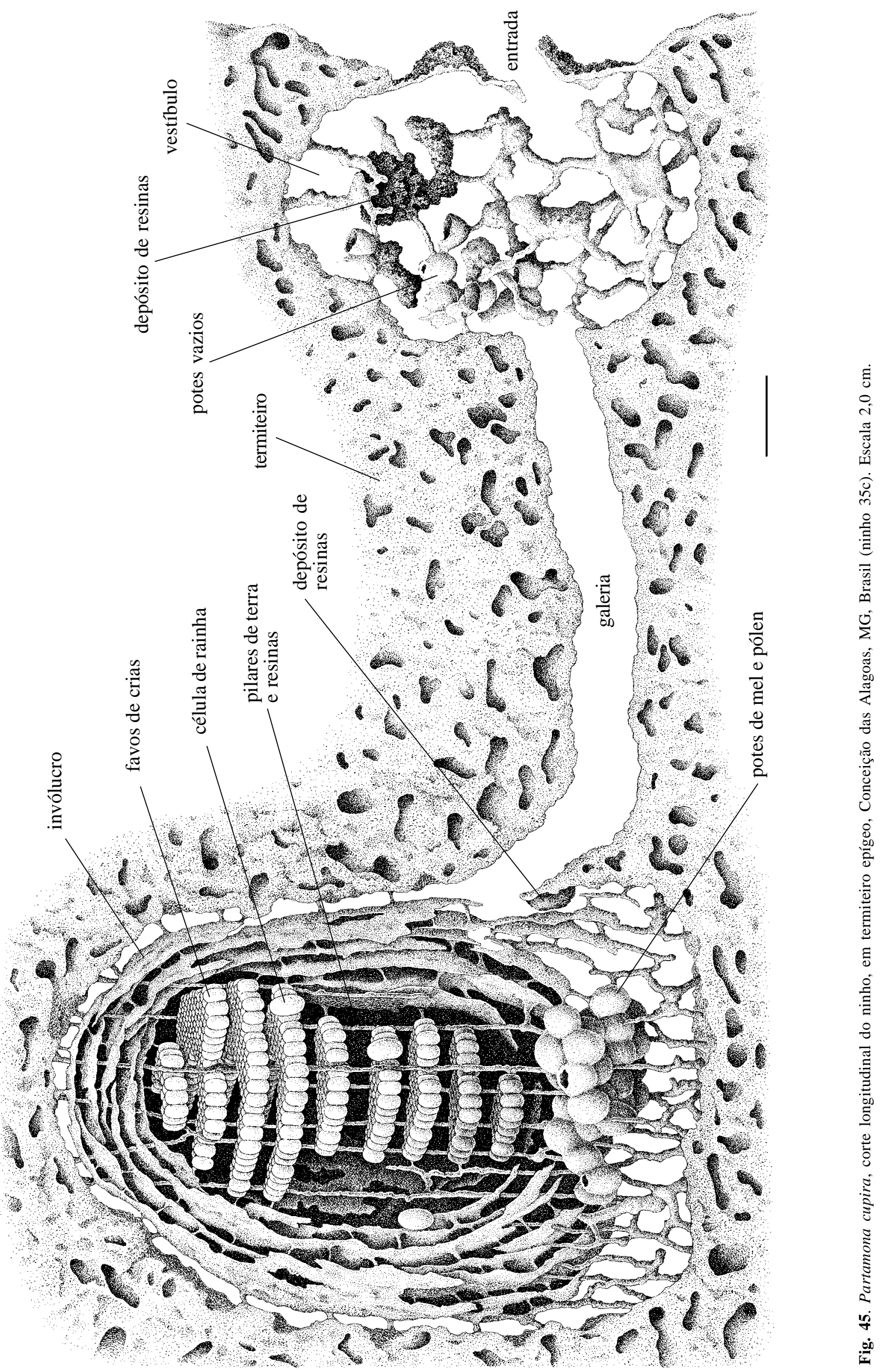



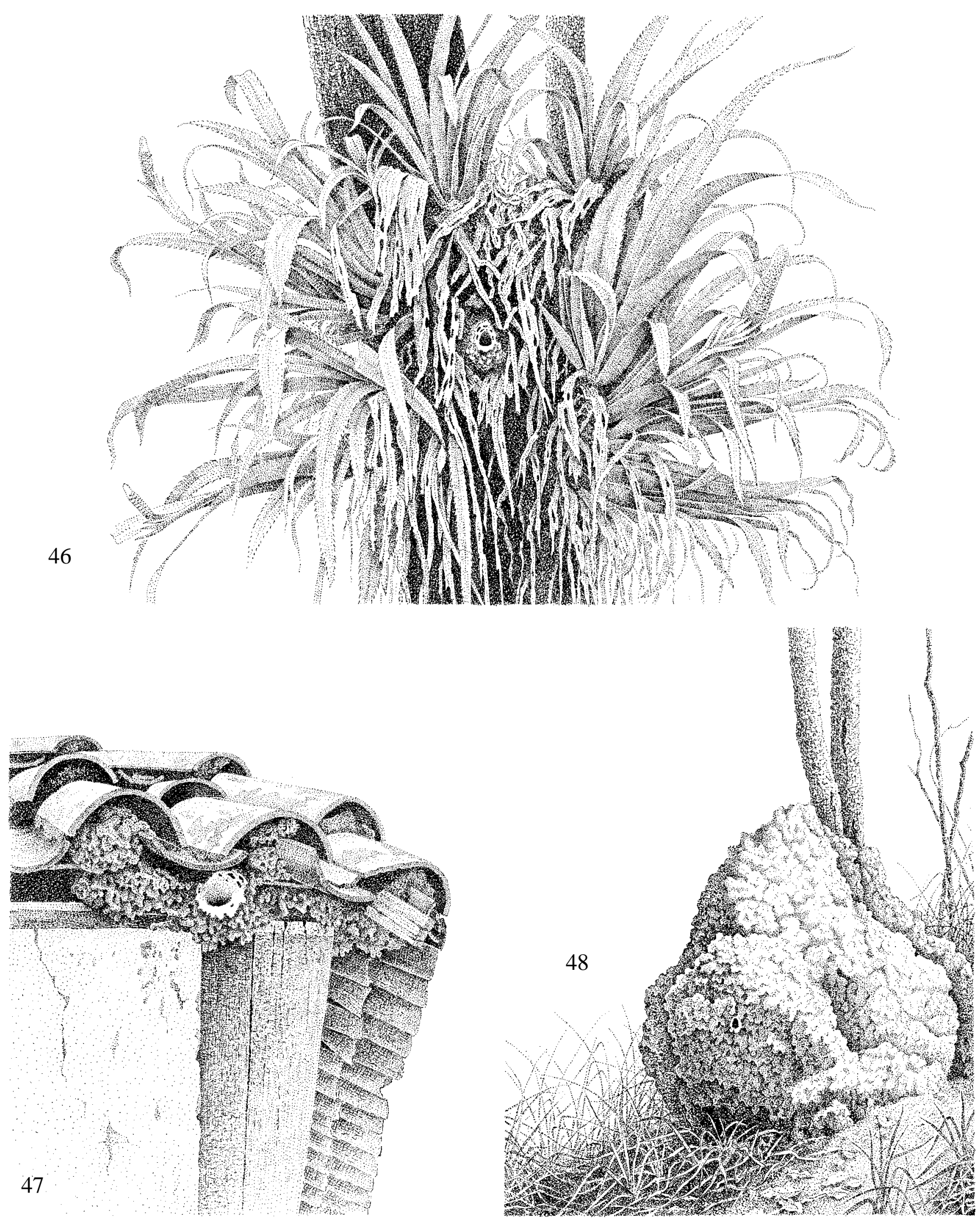

Fig. 46-48. Partamona, ninhos. 46, P. helleri, sob epífita, Ribeirão Preto, SP, Brasil; 47, P. helleri, em beiral de casa, São José do Barreiro, MG, Brasil; 48, P. mulata, ninho em termiteiro epígeo, Cuiabá, MT, Brasil (baseado em foto obtida por R. Ribon). 


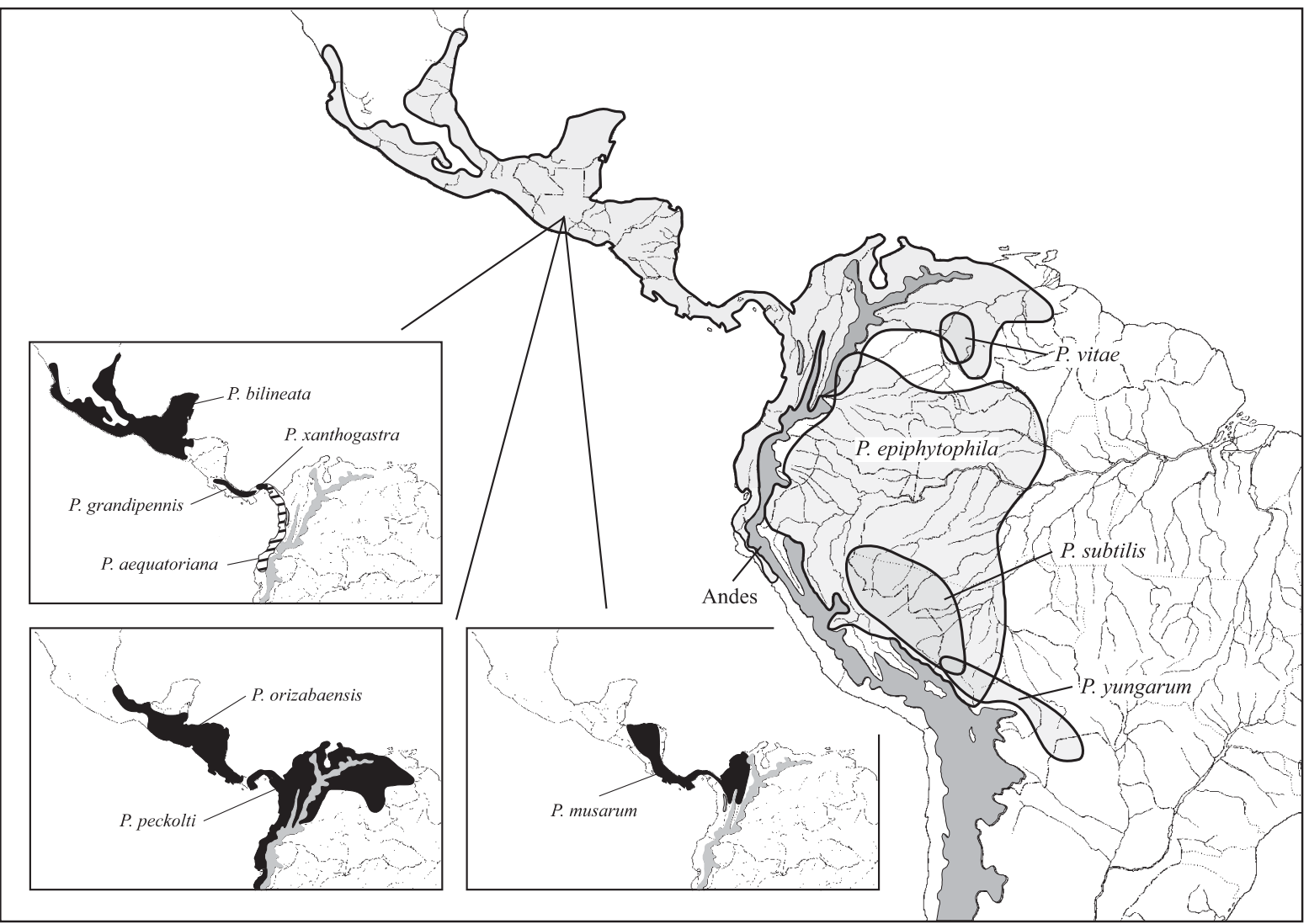

Fig. 49. Distribuição geográfica das espécies de Partamona, grupo bilineata / epiphytophila (modificado de Pedro \& Camargo 2003).

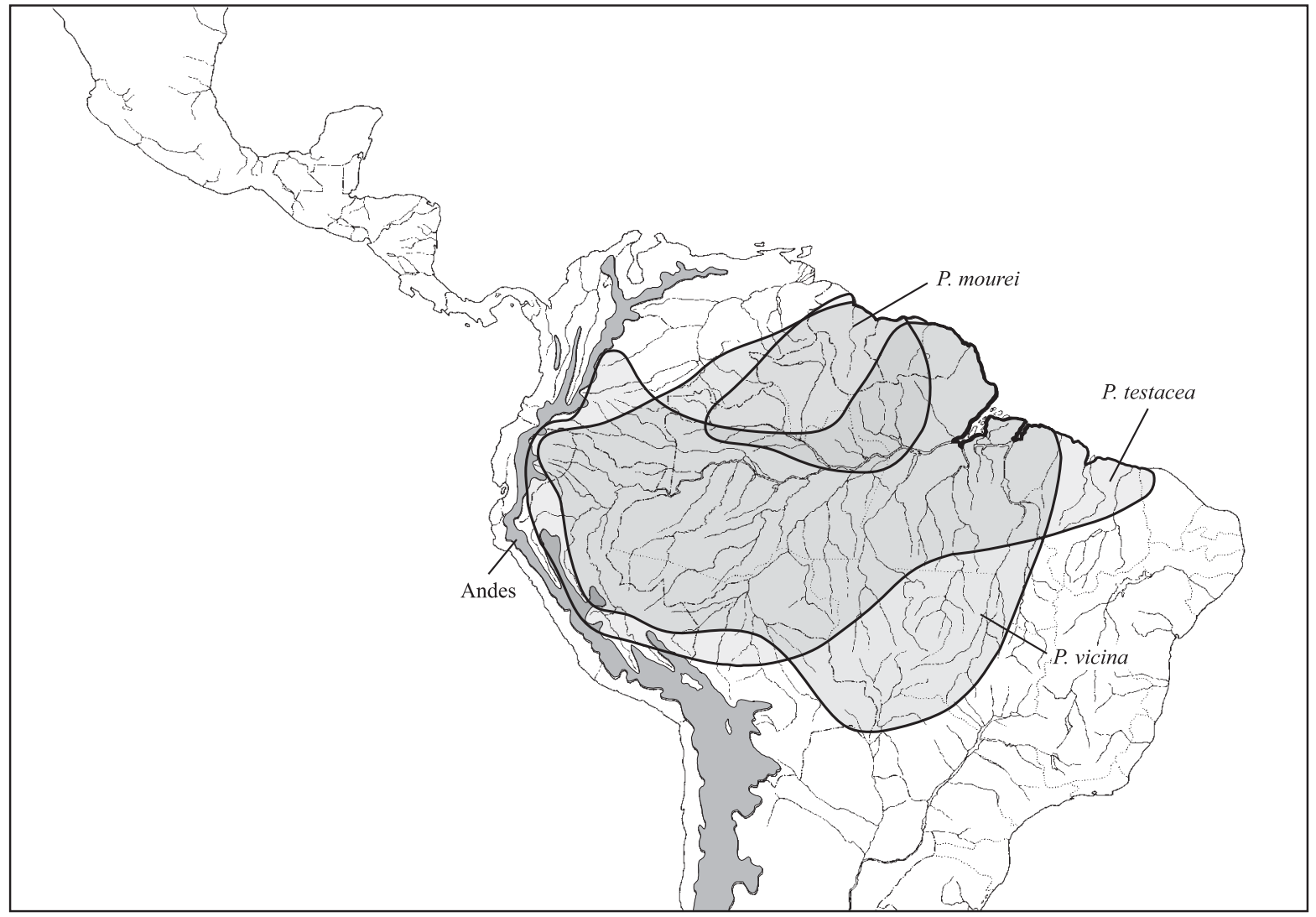

Fig. 50. Distribuição geográfica das espécies de Partamona, grupo testacea (modificado de Pedro \& Camargo 2003). 


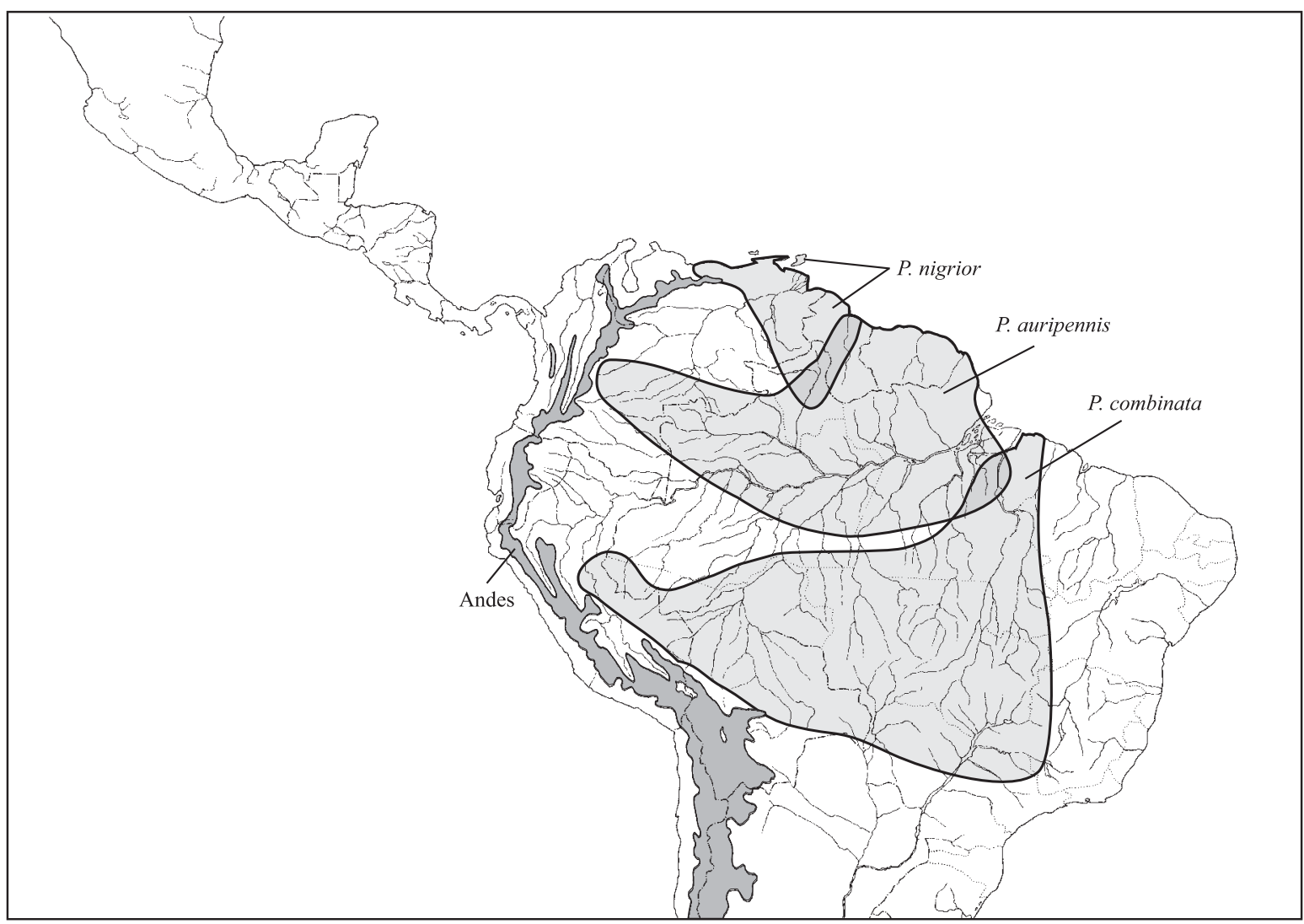

Fig. 51. Distribuição geográfica das espécies de Partamona, grupo nigrior (modificado de Pedro \& Camargo 2003).

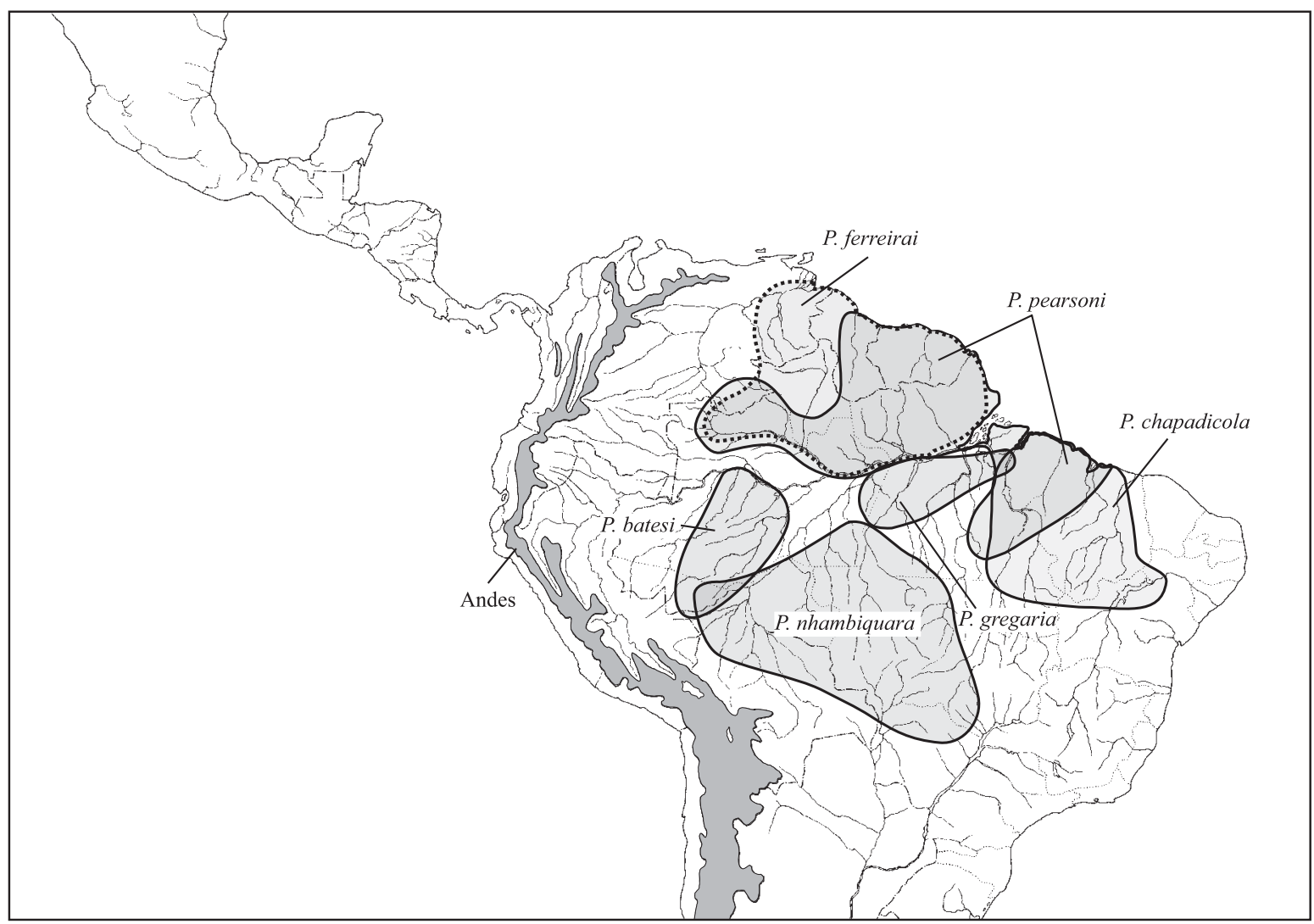

Fig. 52. Distribuição geográfica das espécies de Partamona, grupo pearsoni (modificado de Pedro \& CAmargo 2003). 


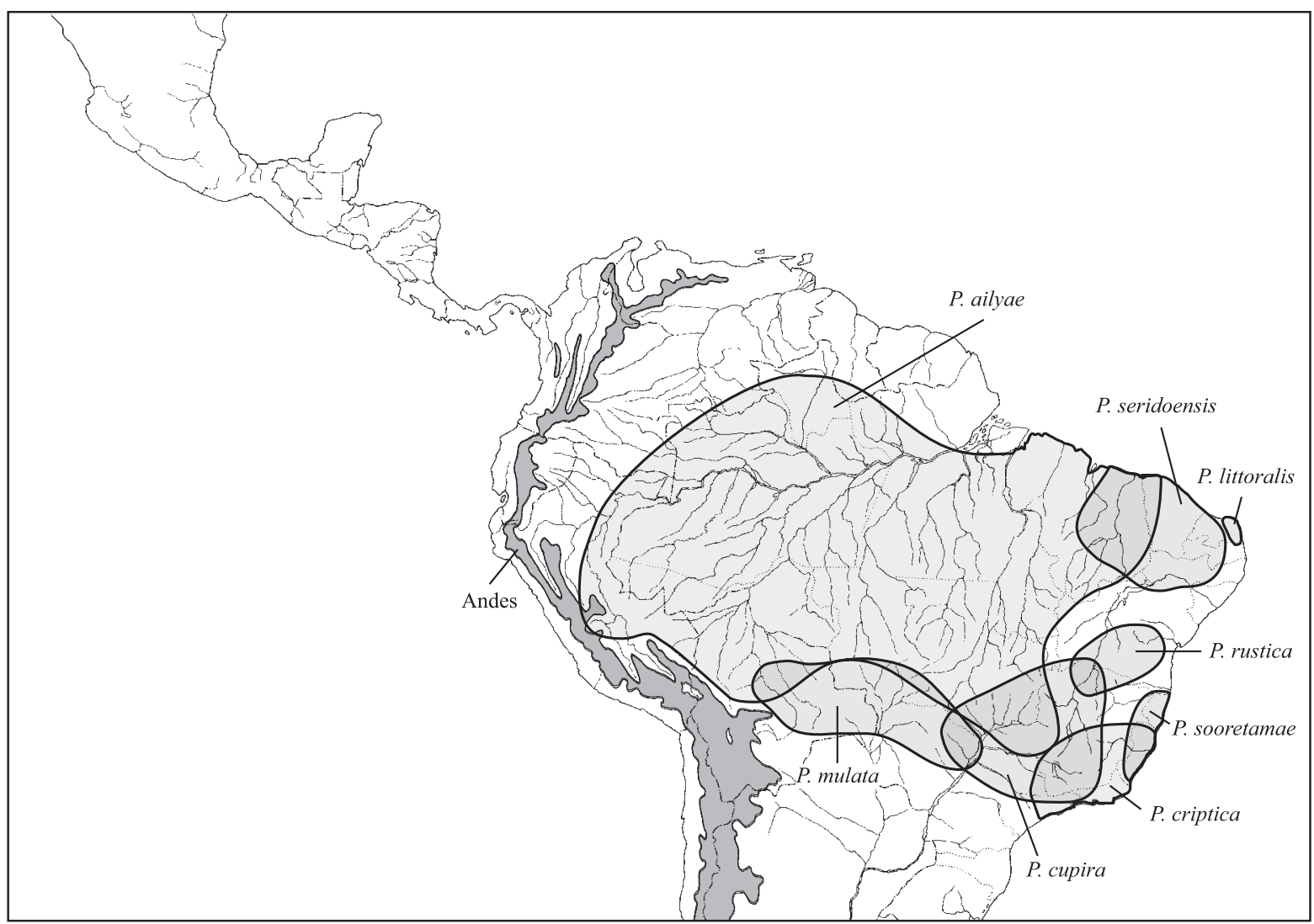

Fig. 53. Distribuição geográfica das espécies de Partamona, grupo cupira (modificado de Pedro \& Camargo 2003).

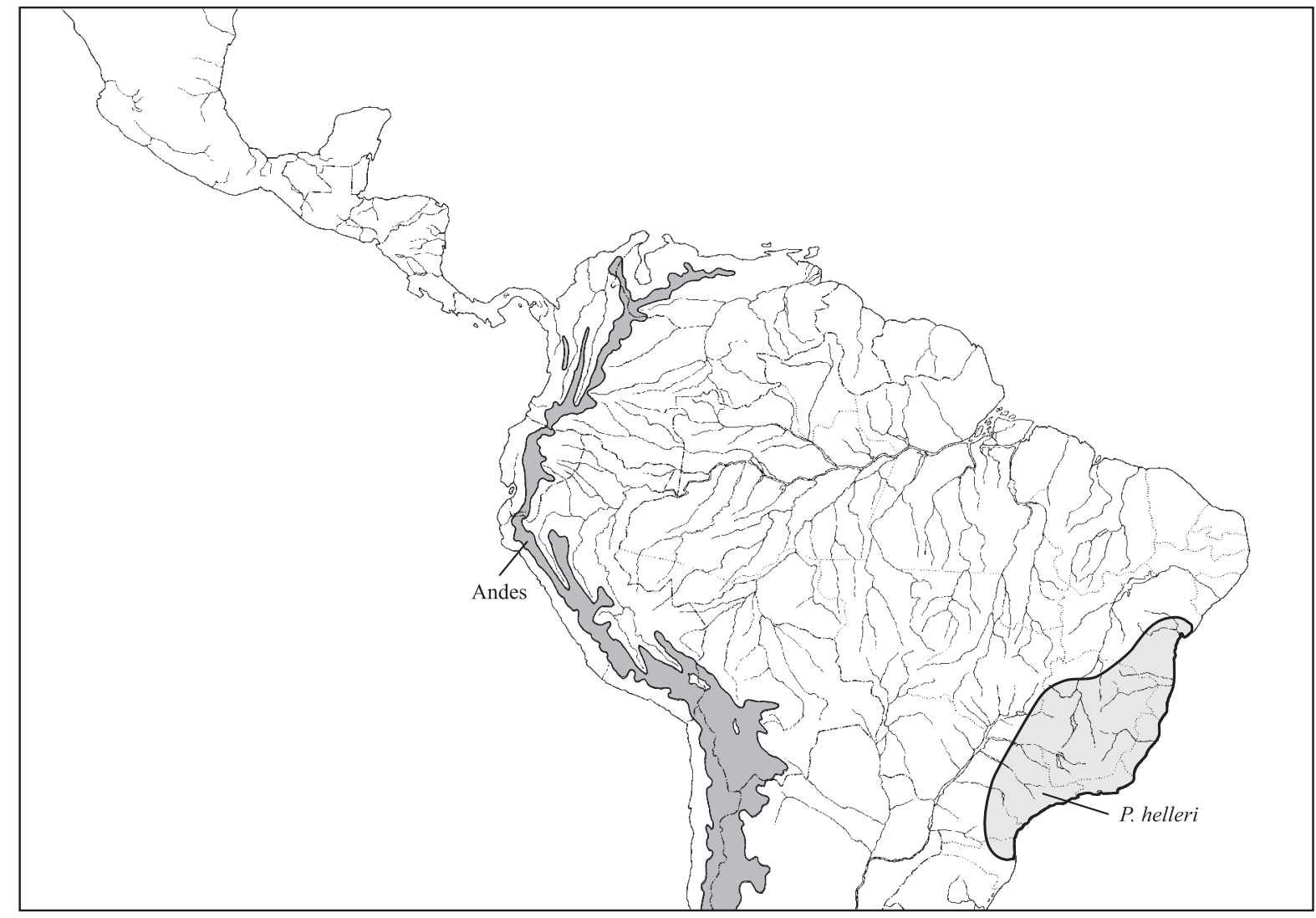

Fig. 54. Distribuição geográfica de Partamona helleri (modificado de Pedro \& Camargo 2003). 


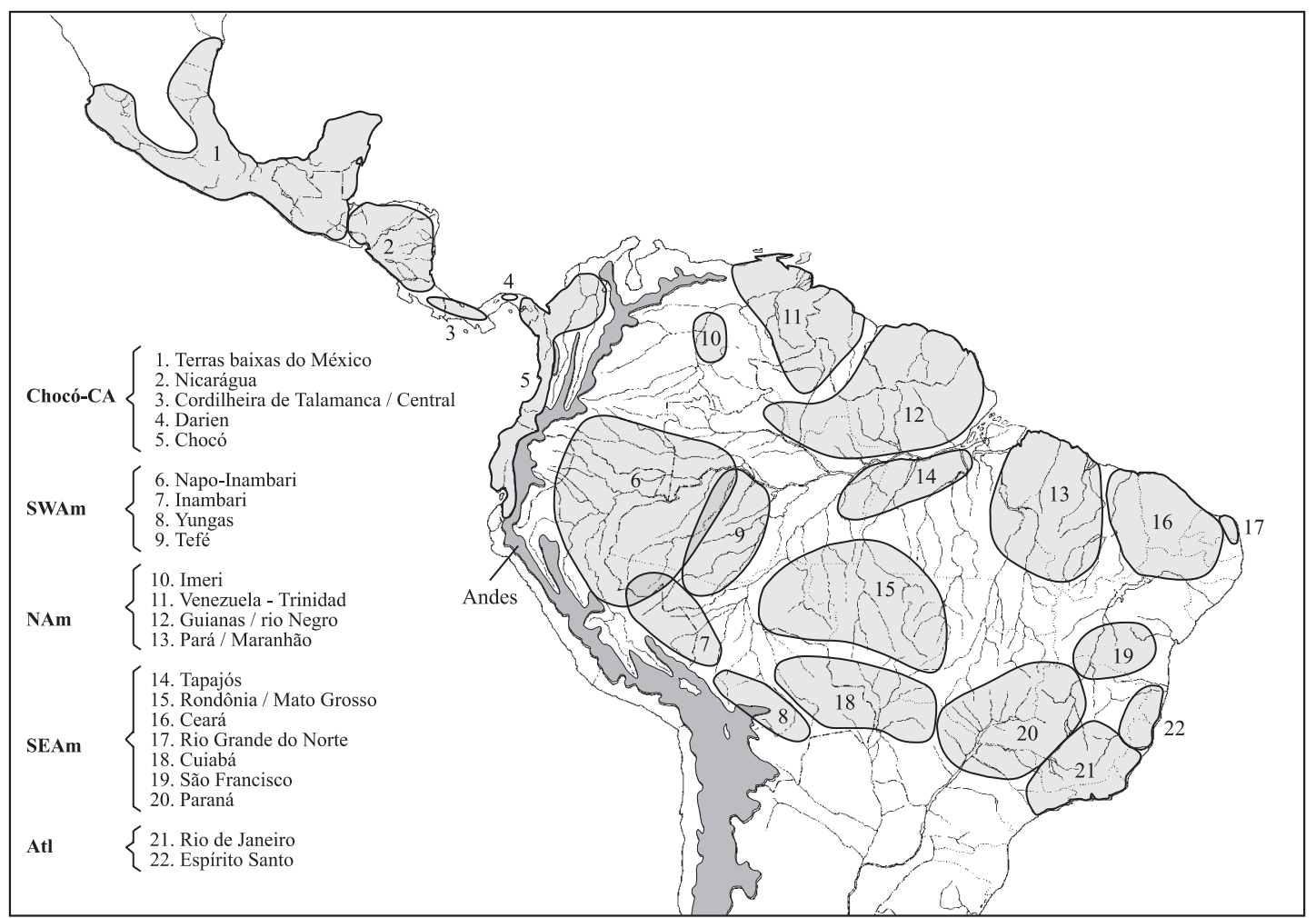

Fig. 55. Áreas de endemismos, ou sub-componentes geográficos, inferidas a partir da distribuição das espécies de Partamona e indicadas na Fig. 58. Os principais componentes biogeográficos são indicados conforme traçados obtidos por CAMARgo \& Moure (1996), CAMARgo (1996a) e Amorim \& Pires (1996) (Fig. 56a): Chocó-CA (do noroeste do Peru até o México), SWAm (componente delimitado, ao norte, pelo alinhamento dos rios Uaupés / Negro, ao sul, pelos rios Madeira / Mamoré, e a oeste pela cordilheira dos Andes), NAm (área ao norte dos rios Negro e Amazonas - cráton Brasil/ Guianas), SEAm (corresponde à área ao sul dos rios Madeira / Amazonas, incluindo todo o Brasil central e nordeste, até ao noroeste da Argentina) e Atl (região atlântica, da Bahia até o Paraná).

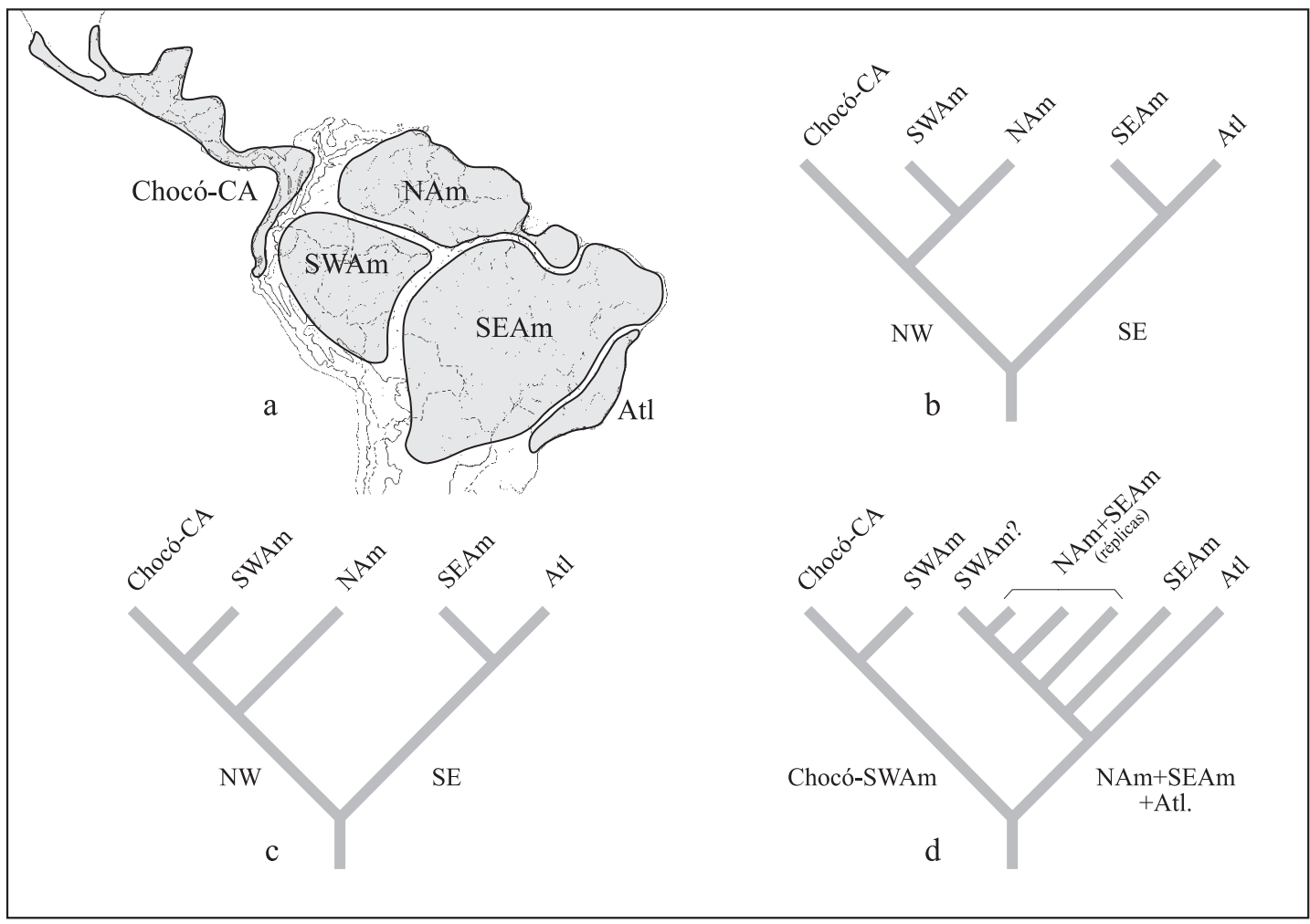

Fig. 56. a, principais componentes biogeográficos que integram a região neotropical (Amorim \& Pires 1996, CAmargo 1996a, CAMARgo \& Moure 1996). Cladogramas de área para os principais componentes: b, conforme Amorim \& Pires (1996); c, conforme Camargo (1996a) e Camargo \& Moure (1996); d, hipótese proposta neste trabalho, conforme cladograma biológico para as espécies de Partamona (Figs. 57, 58). 


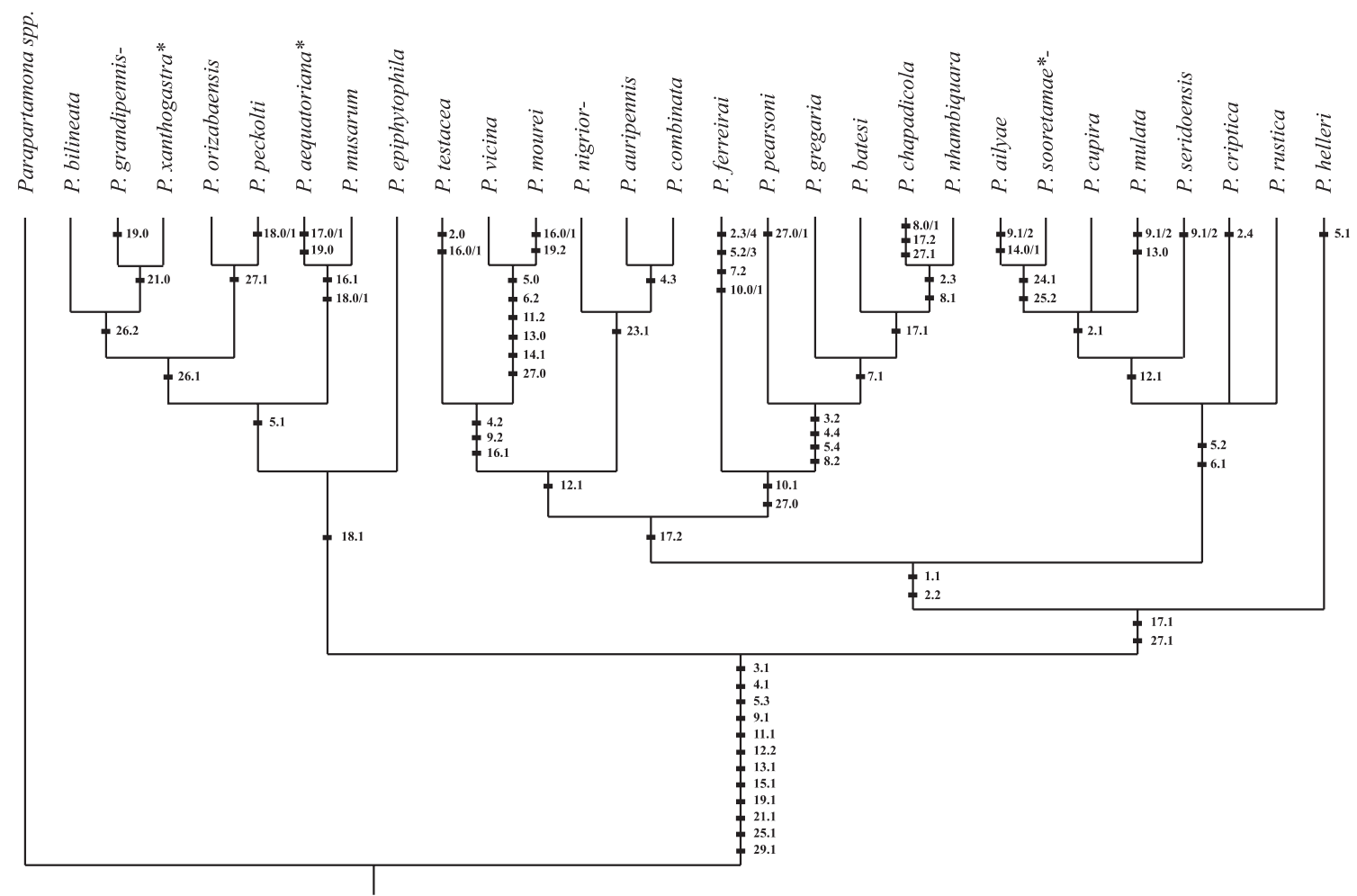

Fig. 57. Hipótese de filogenia para as espécies de Partamona. Uma das 24 árvores filtradas, de um total de 264 árvores de comprimento mínimo, excluídos os táxons $P$. vitae, $P$. yungarum, P. subtilis, P. littoralis e caracteres 20, 22, 28, e ordenados os caracteres 3, 6, 11, 25 e 26 (Tab. III; PAUP, comprimento 76, índice de consistência 0,789 , índice de retenção, 0,855 , índice de consistência reescalonado 0,675$)$ * macho não conhecido; ninho não conhecido.

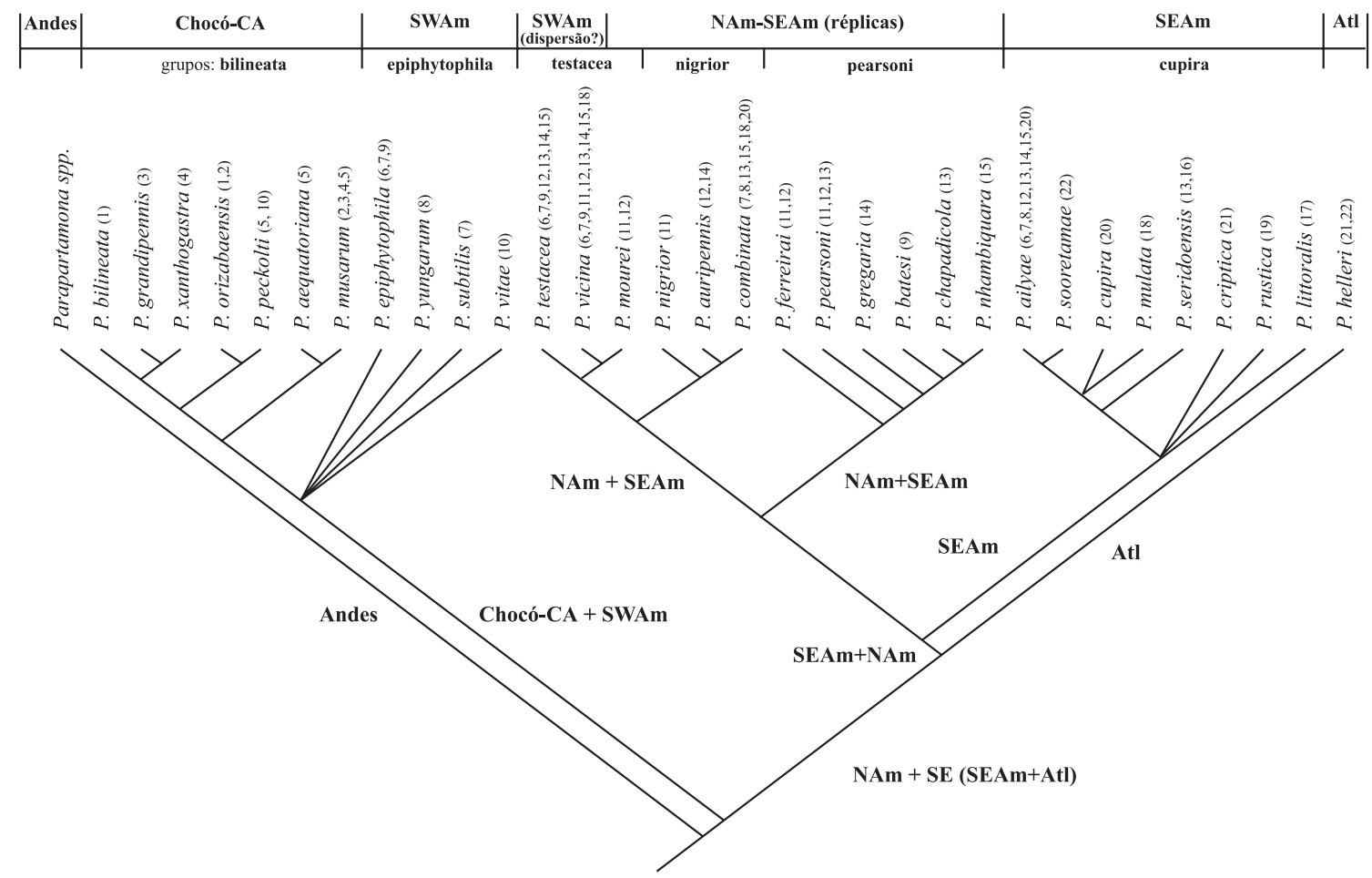

Fig. 58. Hipótese de filogenia para as espécies de Partamona apresentada na Fig. 57, implementada com o auxílio do programa MacClade, incluindo todos os táxons (Tab. III). Componentes biogeográficos indicados conforme traçados obtidos por CAmargo \& Moure (1996), CAmargo (1996a) e Aмorim \& Pires (1996) (Figs. 55, 56). Os números entre parênteses indicam as áreas de endemismos conforme Fig. 55. Os padrões distribucionais estão indicados nas Figs. 49-54. 